\title{
Inovações tecnológicas e a complexidade do sistema econômico
}

\author{
Carolina Marchiori Bezerra
}

BEZERRA, CM. Inovações tecnológicas e a complexidade do sistema econômico [online]. São Paulo: Editora UNESP; São Paulo: Cultura Acadêmica, 2010. 122 p. ISBN 978-85-7983-089-1. Available from SciELO Books <http://books.scielo.org>.

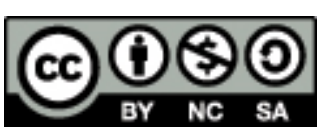

All the contents of this chapter, except where otherwise noted, is licensed under a Creative Commons Attribution-Non Commercial-ShareAlike 3.0 Unported.

Todo o conteúdo deste capítulo, exceto quando houver ressalva, é publicado sob a licença Creative Commons Atribuição Uso Não Comercial - Partilha nos Mesmos Termos 3.0 Não adaptada.

Todo el contenido de este capítulo, excepto donde se indique lo contrario, está bajo licencia de la licencia Creative Commons Reconocimento-NoComercial-CompartirIgual 3.0 Unported. 
INOVAÇÕES

TECNOLÓCICAS E A

COMPLEXIDADE

DO SISTEMA

ECONÔMICO

CAROLINA MARCHIORI BEZERRA 


\section{INOVAÇÕES TECNOLÓGICAS E A COMPLEXIDADE DO SISTEMA ECONÔMICO}


Conselho Editorial Acadêmico

Responsável pela publicação desta obra

Prof. Dr. Eduardo Strachman (Coordenador)

Prof. Dr. André Luiz Correa

Prof. Dr. Enéas Gonçalves de Carvalho

Prof. Dr. Marcelo Pinho

Prof. Dr. Rogério Gomes 
CAROLINA MARCHIORI BEZERRA

\author{
INOVAÇÕES \\ TECNOLÓGICAS E A \\ COMPLEXIDADE DO \\ SISTEMA ECONÔMICO
}

CULTURA

$\frac{\text { ACADÊMICA }}{\mathcal{E} \text { diton } a}$ 


\section{(c) 2010 Editora UNESP}

\section{Cultura Acadêmica}

Praça da Sé, 108

01001-900 - São Paulo - SP

Tel.: $(0 x \times 11)$ 3242-7171

Fax: (0xx1 1) 3242-7172

www.editoraunesp.com.br

feu@editora.unesp.br

CIP- Brasil. Catalogação na fonte

Sindicato Nacional dos Editores de Livros, RJ

B469i

Bezerra, Carolina Marchiori

Inovações tecnológicas e a complexidade do sistema econômico /

Carolina Marchiori Bezerra. - São Paulo : Cultura Acadêmica, 2010.

122p. : il.

Inclui bibliografia

ISBN 978-85-7983-089-1

1. Economia. 2. Economia evolutiva. 3. Inovações tecnológicas.

4. Desenvolvimento econômico. I. Título.

10-6451.

CDD: 330

CDU: 330

Este livro é publicado pelo Programa de Publicações Digitais da Pró-Reitoria de Pós-Graduação da Universidade Estadual Paulista "Júlio de Mesquita Filho" (UNESP)

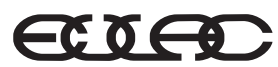

Asociacion de Editoriales Universitarias de América Latina y el Caribe

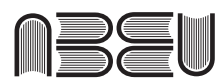

Associação Brasileira de Editoras Universitárias 


\section{SUMÁRIO}

Introdução 7

1. A abordagem evolucionária como uma alternativa ao reducionismo da microeconomia tradicional 11

2. Os sistemas complexos 49

3. O processo de inovação tecnológica de uma perspectiva agent-based 77

Conclusões 109

Referências bibliográficas 115 



\section{INTRODUÇÃO}

O interesse pelo tema proposto busca entender o processo de inovação tecnológica dentro de um sistema econômico que é entendido como complexo. A opção por essa perspectiva tem como objetivo compreender o processo inovativo a partir de uma matriz teórica distinta daquela desenvolvida pela microeconomia tradicional, que, em virtude do seu caráter de construção estática, não é capaz de incorporar propriedades da inovação tecnológica e mudanças estruturais.

Ao avaliar as principais premissas da teoria microeconômica tradicional, verifica-se que esta contém atributos que, de certa forma, comprometem o poder explicativo dos seus modelos, sobretudo aqueles que remetem à noção de equilíbrio geral. Grosso modo, esses modelos apresentam tanto um distanciamento da realidade por incorporar características imaginárias dos atores sociais e dos mercados enquanto instituições, como um modo mecânico de apreender as interações sociais. Em particular, não são capazes de levar em consideração a dinâmica de fenômenos econômicos e a complexidade das interações e relações que se travam nessa esfera entre os agentes e entre estes e o ambiente. É em função desses aspectos que alguns críticos classificam a teoria neoclássica como reducionista e, dessa perspectiva, o todo consiste na mera composição das suas 
partes constituintes, sendo este um ponto importante a ser aclarado mais à frente.

Uma das principais consequências desse reducionismo é a limitação da abordagem neoclássica tradicional em lidar com o processo de inovações tecnológicas, ${ }^{1}$ fato que abriu espaço para o desenvolvimento de modelos de inspiração schumpeteriana. $\mathrm{Na}$ obra de Schumpeter, a inovação passa a ser enxergada como a principal responsável pela criação de diversidade e variedade no sistema, afastando o sistema das posições de equilíbrio. A inovação também é considerada a principal responsável pelo desenvolvimento econômico.

Dando prosseguimento ao desenvolvimento dessas ideias, a partir da atualização e incorporação de novos elementos à concepção de Schumpeter, a abordagem neo-schumpeteriana, igualmente conhecida como evolucionária, apresenta-se como uma alternativa às deficiências imputadas à abordagem neoclássica tradicional, uma vez que permite compreender a inovação, isto é, a introdução de novidades, como uma mudança descontínua que altera as condições estruturais e afasta a economia das posições de equilíbrio. Cabe ressaltar que a abordagem neo-schumpeteriana está mais interessada em explicar as diferentes propriedades do processo inovativo e como as diferentes combinações dessas propriedades geram assimetrias entre os agentes.

É nesse contexto que a teoria dos sistemas complexos, ao apresentar um arcabouço não reducionista da análise que tem uma perspectiva evolucionária e sistêmica, concebe a economia como um sistema adaptativo, complexo e que é capaz de auto-organização. Tornou-se, por isso, uma alternativa no campo da ciência econômica.

Uma vez feitas essas considerações iniciais, o presente trabalho pretende discutir em que se constituem esses sistemas complexos, como as inovações tecnológicas são entendidas nesse

1. Segundo essa abordagem, as inovações seriam incapazes de produzir grandes alterações no sistema. 
arcabouço e, ainda, como essa análise pode contribuir para o avanço da economia.

Para atingir o objetivo acima, o trabalho foi dividido em três capítulos além desta introdução e da parte conclusiva. No primeiro capítulo são feitas algumas considerações críticas às peculiaridades da microeconomia tradicional. Essa avaliação inicial visa identificar suas limitações com o objetivo de verificar sob quais condições se dá a introdução de uma nova perspectiva de análise cujas principais características podem ser creditadas à abordagem evolucionária. Diante disso, torna-se importante realizar um estudo do que se considera a origem dessas ideias. Com isso pretende-se contrapor essas duas visões a partir do tratamento de ambas no plano dos indivíduos e no plano agregado, e também do modo como tratam as inovações tecnológicas diante desse contexto.

O segundo capítulo tem por objetivo identificar as principais características dos sistemas complexos. Mais especificamente, pretende-se discutir as origens e os instrumentos teóricos dessa abordagem para finalmente, no terceiro capítulo, tratar o processo de inovação tecnológica dentro desse contexto a partir da avaliação e descrição de alguns modelos realizados nessa área, os quais são em grande parte baseados no modelo de concorrência schumpeteriana desenvolvido por Nelson \& Winter ([1982]/2005). O pensamento e a obra desses autores passaram a ser vistos como referência para a abordagem evolucionária, oferecendo importantes contribuições, especialmente na esfera da mudança tecnológica.

O capítulo discute ainda, de maneira mais detalhada, as hipóteses do modelo de concorrência schumpeteriana de Nelson \& Winter ([1982]/2005), e também como os argumentos e observações desenvolvidos por essa literatura podem ser aproximados do método de modelagem baseado no agente dos sistemas complexos. O quarto e último capítulo será composto pelas considerações finais do trabalho. 



\section{1 \\ A ABORDAGEM EVOLUCIONÁRIA COMO UMA ALTERNATIVA AO REDUCIONISMO DA MICROECONOMIA TRADICIONAL}

\section{A teoria neoclássica e sua abordagem reducionista}

Este capítulo tem por objetivo realizar uma breve análise crítica das principais peculiaridades da microeconomia tradicional, também conhecida como reducionista, para, em seguida, verificar sob quais condições se dá a introdução de uma nova perspectiva de análise.

Para Arnsperger \& Varoufakis (2006), a economia neoclássica é identificada a partir de três axiomas principais, os quais são descritos como meta-axiomas: i) individualismo metodológico, situação em que as explicações socioeconômicas são procuradas na esfera dos indivíduos constituintes e das relações entre eles; ii) instrumentalismo metodológico, que é entendido como um meio de maximização das preferências que são dadas, correntes e completamente determinadas; e iii) equilíbrio metodológico.

O domínio da abordagem neoclássica no mainstream econômico pode ser atribuído sobretudo ao uso de suposições bastante restritivas, as quais conferiram a essa teoria uma relativa atratividade no trato dos problemas econômicos, uma vez que tais suposições, ao 
exigirem simplificações e abstrações, permitem a utilização de modelos formalizados matematicamente.

A microeconomia neoclássica ou reducionista baseia-se na teoria do equilíbrio geral. Proposta originalmente por Leon Walras ([1874]/1996) - e elaborada com maior rigor e sofisticação formal por Gerard Debreu (1959), Kenneth Arrow \& Frank Hahn (1971)-, ela está calcada nos pressupostos de mercados concorrenciais e de moeda neutra. Os agentes, ofertantes e demandantes de bens e serviços, são tomadores de preços (estabelecidos em um processo de tatonnement $)^{1}$ que maximizam suas utilidades, considerando os preços de todas as alternativas possíveis. Esses preços, por sua vez, se ajustam em função da demanda (determinada no ponto em que a relação utilidade marginal/preço é equivalente para todas as mercadorias). A oferta e a procura, vistas como mera agregação, respectivamente, dos ofertantes e demandantes individuais, se igualam em todos os mercados.

Segundo Prado (2006), é possível enxergar a microeconomia reducionista ou neoclássica atuando em dois níveis de análise: uma no plano dos indivíduos e outra no plano agregado. Partindo-se da análise no plano dos indivíduos, como visto anteriormente, a microeconomia reducionista adere ao individualismo metodológico, situação em que as explicações dos fatos econômicos ou sociais são construídas com base em suposições relativas ao indivíduo, isto é, são construídas em relação aos indivíduos constituintes, ou, ainda, são reduzidas ao plano dos indivíduos.

1. Esse processo consiste em um mecanismo de contratos virtuais sucessivos que determinam os preços de mercado. Se tais preços satisfizerem a condição de market clearing, isto é, de que não exista excesso de demanda nos diversos mercados interdependentes, eles serão considerados preços de equilíbrio e os contratos serão fechados. Se, por outro lado, houver excesso de demanda em algum mercado, haverá a recontratação, isto é, o mercado emite novos sinais de preços, aos quais os agentes se reajustam, calculando suas novas ofertas e demandas, até que o equilíbrio seja atingido. Para ilustrar como o mercado emite novos sinais de preço, Walras usou a metáfora de um leiloeiro. 
Nessa construção teórica entendida como reducionista, a sociedade não exerce nenhuma influência sobre os indivíduos, que são independentes entre si e definidos exclusivamente a partir das suas propriedades intrínsecas. Para estabelecer conexões entre os indivíduos e o todo, a abordagem reducionista considera que as propriedades globais são o resultado da mera agregação dos componentes individuais, isto é, elas são extraídas das ações dos indivíduos, o que significa dizer que a estrutura, ou o todo, são sempre explicados em termos de suas partes constituintes, e são entendidos como "resultados gerados por meio de interações que se somam, ou seja, como agregações" (Prado, 2006, p.305). Nessa estrutura, qualquer propriedade econômica ou social aparece sempre como algo resultante das propriedades desses indivíduos, que são atômicos ${ }^{2}$ e agem com racionalidade substantiva. ${ }^{3}$

De acordo com o segundo axioma da teoria neoclássica - o instrumentalismo metodológico -, as decisões tomadas nesse ambiente composto por agentes autodeterminados, que possuem racionalidade perfeita e agem para obter o melhor resultado privado possível, são maximizadoras.

Não existem problemas de informação crônica. Todas as deficiências de informação que aí aparecem podem ser superadas a partir do uso do conceito de risco probabilístico, segundo o qual os resultados são conhecidos, tanto através do cálculo a priori, como através das estatísticas da experiência passada. Assim sendo, o risco denota uma condição na qual os resultados e as suas respectivas probabilidades de ocorrência são sempre estabelecidos com antecedência. Os agentes aqui são capazes de avaliar qualquer tipo de incerteza probabilisticamente, ou seja, são capazes de prever todos os resultados futuros e incertos, uma vez que seus objetivos e restrições são conhecidos e dados. Para atingir esse objetivo, os agentes

2. Aqui, os indivíduos, que são pequenos em relação ao todo, não são capazes de modificar as decisões dos demais agentes.

3. Sobre a noção de racionalidade substantiva de Simon: o conhecimento é pleno, as expectativas são corretas e o resultado da ação é certo (Prado, 2006). 
utilizam todas as informações disponíveis no seu processo de decisão, uma vez que são capazes de classificá-las e computá-las. Isto lhes confere uma condição de não cometerem erros sistemáticos na realização das suas escolhas, dado que possuem um entendimento correto das suas consequências, o que significa dizer que conhecem todas as alternativas, de tal modo que tomam a melhor decisão e não têm nenhum incentivo para mudar. Nesse ambiente, os agentes econômicos apenas se adaptam às pequenas mudanças que ocorrem no meio, as quais são consideradas contínuas e friccionais, o que garante a premissa de que não existe a possibilidade de produzir grandes alterações no sistema econômico.

No plano agregado, a teoria neoclássica procura entender as propriedades inerentes aos mercados. Estes, por sua vez, são capazes de promover estabilidade, de modo que as imperfeições e as falhas de mercado passam a ser consideradas apenas desvios que podem ser eliminados com medidas corretivas.

Assim, quando os mercados estão em desequilíbrio, ${ }^{4}$ as próprias forças de mercado corrigirão automaticamente essa condição, utilizando-se, para tanto, do ajuste nos preços via processo de tatonnement. Nesse processo, o leiloeiro walrasiano tem uma função significativa, dado que o seu papel consiste em anunciar os preços do mercado aos agentes econômicos, de tal modo que essas informações possam ser processadas e utilizadas para os seus planos de consumo e de produção. A economia, assim, tateia para uma posição de equilíbrio em todos os mercados, e o leiloeiro age até que um vetor de preços de equilíbrio seja atingido (Kreps, 1990).

Em síntese, é possível dizer que os fenômenos agregados são explicados como equilíbrios; e estes, por seu turno, são derivados dos axiomas que descrevem o que supostamente ocorre na mente dos indivíduos substantivamente racionais, ou seja, otimizadores. Cabe realçar que essa teoria sugere que qualquer pequena pertur-

4. Caracterizado por excesso de demanda e/ou oferta em um determinado mercado. 
bação que ocorra nesses mercados é incapaz de tirar a economia do equilíbrio.

Ingrao \& Israel (1990) apontam que a teoria do equilíbrio geral, ao longo do século XX, ancorada no individualismo metodológico e no método axiomático, manteve o núcleo paradigmático constante e empreendeu um significativo esforço de formalização matemática, com o objetivo de corroborar os seguintes resultados: i) a existência de equilíbrio; ii) a unicidade desse equilíbrio; e iii) a estabilidade global do equilíbrio.

Essa construção teórica tem sido objeto de diversas críticas, isso porque, apesar de certos autores considerarem ter identificado algumas soluções satisfatórias para os problemas relacionados à existência de equilíbrio, a unicidade e a estabilidade ainda carecem de uma resposta mais consistente.

Ingrao \& Israel (1990) ressaltam que os trabalhos de Arrow e Debreu, baseados nas hipóteses walrasianas, foram capazes de demonstrar a existência de equilíbrio geral, mas, no que tange à questão da unicidade do equilíbrio, os autores consideram as soluções existentes bastante divergentes, sendo algumas delas sem nenhum sentido econômico. Vale destacar que a unicidade do equilíbrio só poderia ser demonstrada pela adoção de restrições ad hoc, como a suposição de que a sociedade se comporta como se fosse um único indivíduo.

Quanto à questão relativa à estabilidade global, os resultados alcançados também são bastante insatisfatórios, estando relacionados com a amplitude dos afastamentos do equilíbrio e com a ocorrência ou não de processos cumulativos que promovam a divergência ou a convergência ao equilíbrio. Disso segue que os equilíbrios podem ser indeterminados e também instáveis.

Outra importante consideração a ser feita se refere às críticas dirigidas ao mercado de reivindicação contingente de Arrow-Debreu. Este considera que todas as escolhas de mercado são feitas de uma única vez, colapsando o futuro no presente. Aqui, o problema de escolha dinâmica é reduzido a um problema estático, e isso é devido à hipótese de racionalidade dos agentes, dado que, segundo essa 
abordagem, os agentes são capazes de prever os preços futuros (Kreps, 1990). Hahn (1981) aponta para algumas deficiências dessa análise, dentre elas: i) a não existência de mercados futuros para todos os mercados; ii) a assimetria de informações; iii) a possibilidade de trocas custosas.

Hahn considera ainda que a teoria do equilíbrio geral, formulada com base em pressupostos bastante restritivos ${ }^{5}$ e fortes simplificações e abstrações, só poderia ser aplicada em economias atomizadas, ou seja, em uma sociedade cujos agentes (demandantes e ofertantes) sejam tão numerosos e pequenos em relação ao mercado que não teriam nenhum poder sobre ele. Qualquer situação distinta dessa implicaria uma teoria inconsistente e incompleta. ${ }^{6}$ Somadas a isso, a hipótese de individualismo metodológico e as explicações dos fenômenos econômicos a partir dos indivíduos resultam em grande simplificação e abstrações, uma vez que as partes devem ser consideradas como dadas. Para Hodgson (1999), apesar de o recurso da redução ser, algumas vezes, inevitável, necessário e desejável, o completo reducionismo é impossível, uma vez que as partes se constituem e se condicionam.

5. As condições necessárias para que se atinja são: 1) os mercados devem ser completos; 2) os agentes devem possuir informação perfeita; 3) os ofertantes e demandantes não podem afetar individualmente os preços; 4) os agentes têm que atuar racionalmente; 5) as preferências devem ser contínuas; 6) as preferências devem ser convexas; 7) os preços devem ser não negativos; 8) o conjunto das possibilidades de produção tem que ser contínuo; 9) o mesmo conjunto tem que ser convexo; 10) os rendimentos têm que ser decrescentes; 11) não pode haver economias de escala; 12) não pode haver externalidades na produção ou no consumo; e 13) todos os bens têm que ser substitutos entre si (Strachman, 2000).

6. Nesse ponto, vale a pena destacar que a descrição rigorosa da operação de uma economia estacionária por Schumpeter é interpretada como um "exercício mental útil para mostrar como seria uma economia de mercado capitalista se as mudanças revolucionárias dinâmicas do desenvolvimento econômico estivessem ausentes. A própria austeridade do modelo de fluxo circularé justificada por Schumpeter com base no sugestivo corolário de que os processos pulsantes da vida econômica no mundo real são mais bem explicados por uma perspectiva explicitamente dinâmica e evolucionária” (Elliott, 1985, p.9-10). 
No mesmo sentido, Possas (1996) aponta que as suposições de preços flexíveis, market clearing e a consideração de que as imperfeições ou falhas de mercados são consideradas apenas desvios de mercado são suposições pouco realistas, uma vez que tais falhas são bastante frequentes no sistema econômico, motivo pelo qual deveriam ser reconhecidas.

Verifica-se, para a abordagem neoclássica, que o problema econômico consiste apenas em selecionar os melhores níveis de produção e distribuição possíveis, uma vez que os conjuntos de escolhas e técnicas disponíveis são conhecidos e dados. Ademais, o lucro decorrente desses níveis de produção atua como um critério de escolha entre essas alternativas. ${ }^{7}$ Portanto, as firmas são vistas como operando de acordo com um conjunto de técnicas e regras de decisão que refletem o seu comportamento maximizador. Entretanto, vale notar que esse caráter estático do modelo não é capaz de incorporar uma função para a inovação, bem como para mudanças estruturais. Disso segue que, diante de um quadro de inovações, a hipótese de comportamento maximizador e equilíbrio torna-se inviável, dando lugar aos pressupostos de desenvolvimento, progresso e evolução. Ademais, de acordo com Nelson \& Winter (1977), a metáfora da maximização dos modelos tradicionais sugerindo definição objetiva das alternativas e o conhecimento pleno de suas propriedades não é capaz de tratar da geração de inovação, uma vez que estabelece um grau fantasioso de inevitabilidade e precisão nas escolhas feitas (Nelson \& Winter, 1977).

Diante de tais limitações, essa questão da inovação é tratada apenas de maneira secundária pela teoria ortodoxa, uma vez que a teoria reducionista não leva em consideração a incerteza em seus modelos, o caráter irregular do avanço técnico e a diversidade das estratégias concorrenciais das firmas.

7. De maneira geral, de acordo com essa abordagem, inventar ou fazer P\&D são atividades cujos resultados podem ser previstos antecipadamente, de tal forma que não existe incerteza quanto às decisões tomadas. 
Nesse sentido, Arnsperger \& Varoufakis (2006) consideram que a abordagem neoclássica vem sofrendo importantes e consideráveis modificações naqueles que foram considerados os seus meta-axiomas. Tais modificações foram empreendidas com o objetivo de lidar com hipóteses mais realistas, e "cobrir" certas lacunas oriundas de suas hipóteses, que, como já fora dito anteriormente, são consideradas simplificadoras, reducionistas e distantes da realidade. Assim, enquanto para os axiomas do individualismo e do instrumentalismo metodológico foram verificadas modificações importantes, a hipótese de equilíbrio metodológico permaneceu intacta.

Alguns modelos neoclássicos mais atuais passaram a lidar com a existência de diversidade entre os indivíduos, abrindo mão da hipótese de indivíduos quase idênticos suposto pela abordagem neoclássica tradicional. Além disso, nesses novos modelos, a estrutura, ou o todo, passou a ser entendida dentro do seu contexto social, com esses modelos considerando que o indivíduo atua sobre a sociedade, e que a sociedade também tem influência sobre o indivíduo.

Em função disso e em concordância com Arnsperger \& Varoufakis (2006), é possível afirmar que não é mais correto identificar a economia neoclássica, a partir da hipótese de existência de agentes perfeitamente racionais, uma vez que se verifica o surgimento de diversos modelos neoclássicos que passaram a lidar com as hipóteses de informação imperfeita e racionalidade limitada, que, por sua vez, se baseiam na premissa de que os indivíduos não são capazes de captar e processar toda a informação disponível. Entretanto, vale notar que, apesar desses avanços, os quais buscaram "cobrir" diversas lacunas oriundas de suas hipóteses simplificadoras e reducionistas, os autores observam que essa teoria ainda continua sustentada pelo e com fortes raízes no individualismo metodológico.

Em alguns casos, a hipótese de maximização de utilidade também sofreu afrouxamento, tendo em vista o fato de que a supo- 
sição de que os indivíduos maximizam alguma função de utilidade o tempo todo é bastante restritiva. Consequentemente, os indivíduos passaram a ser modelados "como se" ("as if") $)^{8}$ maximizassem suas utilidades. Arnsperger \& Varoufakis (2006) apontam, ainda, para o distanciamento das hipóteses de preferências fixas e exógenas até então consideradas e a aproximação, por parte de alguns economistas neoclássicos, de uma literatura das preferências endógenas.

Por fim, vale realçar o papel que a teoria dos jogos passou a desempenhar na teoria econômica, dado que tais recursos permitiram algum avanço em relação à abordagem neoclássica tradicional. Isso porque, de maneira diferente da abordagem neoclássica tradicional, em que as preferências são separadas da estrutura de interação na qual os agentes estão envolvidos e estão ligadas apenas aos resultados, para a teoria dos jogos, os agentes formam convicções sobre as expectativas dos outros, e estas dependem da estrutura social e histórica na qual está embutida (Arnsperger \& Varoufakis, 2006).

Uma vez feita essa breve apresentação dos principais pontos críticos da teoria neoclássica, busca-se, na próxima seção, dar continuidade a este trabalho, mais especificamente no que tange ao tratamento oferecido por essa teoria acerca do processo inovativo.

8. Esse argumento "as if" foi proposto na literatura por Milton Friedman. A partir desse argumento, o autor procura expor uma justificativa metodológica para a utilização dos pressupostos referentes ao comportamento dos agentes econômicos. É utilizado como uma estratégia para a defesa da concepção neoclássica do comportamento racional. Nessa versão assume-se que as pessoas se comportam "como se" ("as if") elas estivessem maximizando uma função de utilidade. O autor argumenta que um certo dispositivo evolucionário, isto é, um certo mecanismo de seleção natural, age sobre os agentes, de modo a favorecer aqueles cujo comportamento seja similar ao proposto pela teoria neoclássica, isto é, de modo a favorecer aqueles que agem como se dominassem os cálculos necessários. 


\section{O tratamento neoclássico das inovações tecnológicas}

A mudança técnica foi inicialmente tratada pelos modelos neoclássicos tradicionais ${ }^{9}$ como uma variável exógena, apresentando-se como o resultado não intencional das escolhas tomadas. ${ }^{10}$ Tais modelos trabalham com as hipóteses de retornos constantes de escala e concorrência perfeita. A concorrência perfeita está relacionada a um estado de equilíbrio e não a um processo que leva à mudança. Sob essa hipótese, os recursos são alocados de maneira eficiente e as firmas, que são idênticas, não são capazes de gerar mudanças nos produtos ou nos métodos de produção.

O progresso técnico é representado por um parâmetro constante na função de produção e, de acordo com essa abordagem, sua alteração reflete-se em deslocamento positivo da fronteira de possibilidade de produção.

Considerando que a função de produção descreve as possíveis combinações de insumos e como estes são transformados em produto, diante de um quadro de progresso tecnológico, as diferentes tecnologias de produção irão gerar diferentes combinações de insumos e, portanto, diferentes produtos e quantidades superiores àquelas obtidas antes da implementação da inovação. Contudo, de acordo com essa abordagem, o progresso técnico não representa uma variável de decisão dos agentes econômicos, dado que é tratado como uma variável exógena que surge na economia automaticamente e que cresce a uma taxa exógena e constante.

Além do mais, a tecnologia é tratada como um bem público puro, que se caracteriza por ser um bem não rival (o que significa que o seu consumo por um agente não impede que seja consumido por outro agente) e não excludente (não há maneira de impedir o consumo do bem por parte de determinado agente). Diante de tais

9. O modelo de crescimento econômico desenvolvido por Solow (1956) apresenta-se como uma das principais representações desse pensamento.

10. Por exemplo, o aperfeiçoamento de habilidade dos consumidores, a realização de P\&D das empresas (Higachi, 2006). 
características, as firmas não possuem poder de mercado e não auferem lucros de monopólio como resultado de suas descobertas (Romer, 1994). Aqui, as diferentes possibilidades tecnológicas estão disponíveis na economia para que as firmas possam escolher e orientar sua produção. Nesse ambiente, não existe incerteza nem diferenças de opinião entre as firmas, uma vez que todas têm o conhecimento técnico e ele está disponível para quem quiser utilizá-lo, de tal forma que os seus resultados podem ser previstos antecipadamente.

As inovações, que representam as possibilidades de mudança nas condições de produção, são tratadas com perfeita racionalidade pelos agentes e as decisões tomadas se dão num contexto de conhecimento também perfeito de todas as possibilidades. Nesse sentido, o objetivo do produtor é apenas identificar essas diferentes tecnologias de produção e escolher aquela que lhe permite maximizar o lucro.

Para Nelson \& Winter (1977, [1982]/2005), a abordagem neoclássica não é adequada para tratar da questão da inovação, uma vez que o seu arcabouço teórico - que parte de uma função de produção bem comportada, que apenas descreve como os insumos são combinados para gerar o produto, e considera como dado o estoque de conhecimento - é bastante limitado. Ademais, tal abordagem anula a existência da incerteza inerente ao processo inovativo ao considerar que os agentes possuem conhecimento perfeito de todas as possibilidades e que, diante disso, tomarão decisões racionais que não levam em consideração a diversidade de comportamento e, tampouco, a complexidade dos sistemas que envolvem o processo de inovação tecnológica.

Segundo Romer (1994), a análise que enxerga a mudança técnica como uma variável exógena se mostrou incapaz de explicar o crescimento verificado na produtividade dos trabalhadores e na renda per capita desde a Revolução Industrial. Com isso, identificou-se a necessidade de se incorporar a mudança técnica na função de produção, o que faz com que essa mudança passe a ser vista não mais como consequência de forças externas, mas como endógena ao sis- 
tema, o que significa dizer que as mudanças vêm de dentro do sistema. O desenvolvimento dos modelos neoclássicos de crescimento endógeno pode ser entendido como um progressivo abandono das hipóteses básicas dos modelos neoclássicos tradicionais.

Outra crítica aos modelos em questão diz respeito à suposição de convergência de longo prazo nas taxas de crescimento entre países pobres e ricos. A abordagem neoclássica padrão, ao considerar a hipótese de rendimentos marginais decrescentes do capital, afirma que no longo prazo haveria uma convergência entre a renda per capita dos países, os quais tenderiam a um equilíbrio estacionário, já que, segundo essa hipótese, os países pobres cresceriam mais rápido, enquanto os países ricos desacelerariam. Os modelos de crescimento endógeno abandonam a hipótese de rendimentos marginais decrescentes e passam a trabalhar com rendimentos marginais constantes ou crescentes. Diante disso, diversos estudos indicaram evidências empíricas que refutam as assertivas anteriores de convergência, dado que, entre outros fatores, diferentes países possuem diferentes oportunidades tecnológicas que devem ser levadas em consideração.

O desenvolvimento dos modelos neoclássicos de crescimento endógeno pode ser dividido em duas fases. A primeira se dá a partir dos trabalhos de Romer (1986) e Lucas (1988), os quais passaram a desconsiderar tanto a hipótese de mudança técnica como exógena ao sistema quanto a de rendimentos marginais decrescentes. Nesse sentido, há uma reconsideração das tratativas acerca das avaliações feitas para diferentes países, de modo que a proposição de convergência entre os países é descartada (Romer, 1994).

Nessa primeira fase de modelos,

a tecnologia é endogenamente proporcionada como um efeito não intencional de decisões de investimento privado. Do ponto de vista dos usuários de tecnologia, é ainda tratada como um bem público puro, assim como no modelo neoclássico. Como resultado, as firmas podem ser tratadas como price takers, podendo existir um equilíbrio com muitas firmas. (Romer, 1994, p.14) 
Esses modelos também partem do pressuposto de que a tecnologia está disponível na economia e pode ser usada por todos os agentes, os quais também têm perfeita racionalidade, mas, diferente dos primeiros, esses modelos colocam ênfase no crescimento econômico como resultado endógeno do sistema econômico e não mais como resultado de forças exteriores ou exógenas.

Para trabalhar com a hipótese de equilíbrio competitivo em modelos que não exibem rendimentos decrescentes, Romer (1986) introduz a ideia de externalidades do nível de capital sobre a função de produção. Isto é, considera-se que os agentes, ao tomarem as suas decisões, não sejam capazes de controlar as externalidades geradas no sistema. Desse modo, as outras firmas serão beneficiadas pelas melhoras implementadas pelas primeiras, evitando, dessa forma, que as firmas cresçam infinitamente, garantindo assim a manutenção da hipótese de equilíbrio do sistema (Ferreira \& Ellery, 1996, p.94).

Os modelos desenvolvidos na segunda fase ${ }^{11}$ viram a necessidade de rever a visão de caráter público do progresso técnico. Verificaram que, diante de tal característica, os inovadores seriam desestimulados de gerar novas pesquisas e de propor mudanças tecnológicas. Destarte, é necessário considerar que a busca de novas tecnologias por parte dos agentes e firmas deve estar relacionada à busca de vantagens financeiras, pois eles não teriam incentivos para investir se não pudessem recuperar os custos com a pesquisa e/ou não pudessem se apropriar dos seus ganhos.

Diante da consideração de que é preciso permitir que os agentes se apropriem de seus lucros a fim de ter incentivos para inovar, esses modelos viram a necessidade de abandonar a hipótese de concorrência perfeita - que pressupõe a ocorrência de lucro normal - e passaram a trabalhar com modelos de equilíbrio geral com monopólio puro, de tal forma que os lucros extraordinários passam a existir e são auferidos pelos inovadores. Segundo Ferreira \& Ellery

11. Esses modelos têm origem nos trabalhos de Romer (1990), Grossman \& Helpman (1991) e Aghion \& Howitt (1992). 
(1996), tais posturas aproximam-se das ideias de Schumpeter, que via no lucro de monopólio ocasionado pelo poder de mercado a verdadeira força motivadora do processo inovativo. Consideram que

alguma forma de monopólio deve ser garantida aos inovadores para que eles tenham incentivo para investir em pesquisa, ou qualquer inovação seria imediatamente copiada e o lucro do inovador seria zero. (Ferreira \& Ellery, 1996, p.88)

Nessa segunda fase, os teóricos desses modelos deparam-se, então, com a necessidade de rever certos conceitos, bem como relaxar certas suposições. Diante disso, a tecnologia passa a ser vista como parcialmente excludente, situação em que os inovadores ao mesmo tempo se apropriam de parte desses resultados econômicos e também evitam que outras firmas ou agentes a consumam, ${ }^{12} \mathrm{o}$ que expressa uma verdadeira condição de incentivo para a realização da atividade inovativa. Por outro lado, não se pode deixar de considerar que a geração de novas tecnologias também suscita externalidades, dado que as firmas concorrentes são capazes de reconhecer as técnicas lucrativas e aplicá-las em seus processos através do processo de difusão tecnológica.

Esse tratamento da mudança técnica como sendo uma variável endógena ao sistema e como determinante do crescimento econômico foi considerado, como visto anteriormente, tanto pelas "novas" abordagens neoclássicas ${ }^{13}$ como pela literatura evolucionista, ${ }^{14}$ a qual destaca, sobretudo, a criatividade e o papel do empresário no processo evolucionário. Para Higachi et al. (1999), os modelos neo-

12. Um exemplo seria o sistema de patentes.

13. Dentre os principais autores, destacam-se: Romer, 1990; Grossman \& Helpman, 1991.

14. Higachi et al. (1999) apontam três classes de modelos evolucionistas que tratam a mudança técnica endógena como determinante do crescimento econômico: os inspirados no modelo desenvolvido por Nelson \& Winter ([1982]/2005); os modelos de inspiração kaldoriana e uma linha que resulta das duas anteriores e de uma extensão da dinâmica não linear de Goodwin (1967). 
clássicos e evolucionários que colocam ênfase na mudança técnica endógena possuem alguns pontos em comum, mas apresentam outros diametralmente opostos. Segundo os autores, eles se aproximam quanto ao

esforço de colocar o conhecimento, a inovação e os retornos crescentes como aspectos fundamentais de seus modelos [...], mas afastam-se [...] nas suposições sobre como os agentes se comportam, como o aprendizado toma lugar e como os mercados funcionam. (p.55)

Especificamente na noção de concorrência schumpeteriana, os empresários introduzem inovações no sistema econômico gerando diversidade de produtos e processos com o objetivo de estabelecer vantagens sobre os seus concorrentes. E são essas diferenças de percepção dos empresários quanto às diferentes tecnologias de produção disponíveis que estabelecerão as distinções entre as firmas quanto a suas tecnologias utilizadas, produtividade e lucratividade.

Os autores neo-schumpeterianos, inspirados na abordagem de Schumpeter acerca da dinâmica capitalista, dão prosseguimento a essa linha de pesquisa na qual a mudança tecnológica é tratada como endógena ao sistema e como a principal responsável pelo crescimento econômico. Diante disso, o arcabouço teórico desenvolvido pelos neo-schumpeterianos representa uma alternativa à abordagem tradicional bastante importante para a construção de uma microeconomia alternativa. Nesses modelos, a inovação e a criatividade são apresentadas como as principais fontes de variedade dos sistemas.

Disso segue que a abordagem evolucionária, ao partir de pressupostos não reducionistas, é capaz de fornecer um tratamento da inovação tecnológica e da mudança técnica mais próximo da realidade do que o apresentado pela teoria neoclássica do crescimento, de tal forma que se torna importante a sua análise. ${ }^{15}$

15. Entretanto, Hodgson (1999) aponta alguns problemas com a ênfase exclusiva na inovação como sendo endógena ao sistema defendida por Schumpeter e 
Segundo Possas (1989b, p.159), os autores neo-schumpeterianos podem ser situados em dois grupos não rivais: os baseados nos trabalhos de Nelson \& Winter ([1982]/2005), que desenvolvem uma abordagem evolucionária; e uma segunda linha que é originária da Universidade de Sussex, que tem dentre seus expoentes Christopher Freeman, Carlota Perez, Keith Pavitt, Luc Soete e Giovanni Dosi. Os dois grupos de autores ou linhas de pensamento estão voltados, sobretudo para:

a análise dos processos de geração e difusão de novas tecnologias em sua natureza e impactos, destacando sua inter-relação com a dinâmica industrial e a estrutura de mercados, neste último caso inclusive lançando mão de modelos de simulação. O critério metodológico é, aqui, o desequilíbrio e a incerteza; o princípio teórico, a concorrência; o autor de referência é, evidentemente, Schumpeter. (Possas, 1989b, p.158)

Assim sendo, busca-se, na seção seguinte, levantar os principais pontos da discussão neo-schumpeteriana da perspectiva dos modelos evolucionários, cujas proposituras sustentam importantes fundamentos dos sistemas complexos, na qual este livro se baseará para rediscutir a questão da inovação tecnológica.

também pelos diversos autores da abordagem evolucionária, na qual são enfatizadas as fontes de mudança de dentro e na qual são os empresários que introduzem as inovações no sistema econômico. Para o autor, tal consideração é problemática, uma vez que a evolução envolve tanto mudanças endógenas ao sistema como exógenas a ele e isto porque as inovações não podem ser atribuídas apenas às ações internas dos indivíduos, mas também estão relacionadas às fontes de mudanças externas, pois "doenças e desastres naturais também podem afetar a evolução econômica. Também são importantes os choques das instituições e sistemas, mais dramaticamente no caso de guerras e invasões" (p.144). Segundo Hodgson, seria mais relevante caracterizar tais sistemas como abertos, em vez de endógenos. 


\section{A teoria evolucionária e sua abordagem sistêmica}

Como já foi afirmado anteriormente, a teoria evolucionária da mudança econômica leva em consideração diversos aspectos da obra de Schumpeter. Dentre os elementos mais importantes da abordagem schumpeteriana ([1943]/1984) identificados como existentes nas abordagens evolucionistas estão: a sua ênfase em aspectos de desequilíbrio, dado que a inovação é considerada um desvio do comportamento rotineiro, e o outro aspecto diz respeito à definição de desenvolvimento econômico como a realização de novas combinações ${ }^{16}$ ou inovações ${ }^{17}$ pelos empresários, o que torna a mudança qualitativa e a geração de variedade econômica fundamental para as alterações na configuração do sistema econômico, o que condiz com a "destruição criativa". ${ }^{18}$

Tais inovações geram efeitos cumulativos em todo o sistema, conduzindo toda a sociedade para um estágio mais avançado de desenvolvimento e isso porque as inovações empreendidas por um grupo de empresários influenciam as decisões dos demais, que, por sua vez, empenham-se em imitar os primeiros. Entretanto, essa possibilidade de imitação pelos demais concorrentes também fará com que os lucros dos inovadores decorrentes da implantação de inovações sejam menores, uma vez que passarão a ser divididos entre os concorrentes. A ocorrência desse fato reduziria o incentivo que as empresas têm para inovar, o que tenderia a tornar o sistema automatizado e rotinizado. Desse modo, condições de apropriabilidade deveriam ser garantidas para que os agentes continuassem tendo incentivos para inovar.

16. As inovações constituem, em grande medida, a recombinações de materiais conceituais e físicos que já existiam previamente.

17. Essas inovações podem ser de novos produtos, novos processos de produção, novas fontes de matéria-prima e novas formas de organização industrial (Saviotti \& Metcalfe, 1991).

18. Na noção de "destruição criativa" schumpeteriana, o novo supera o velho, isto é, a estrutura econômica anterior é destruída em favor da criação de uma nova estrutura, que é melhor do que a anterior. 
Nessa teoria, o crescimento econômico é enxergado como um processo evolucionário impulsionado pela mudança tecnológica. São, portanto, os avanços tecnológicos, considerados endógenos e idiossincráticos, que guiam o crescimento econômico.

Nesta seção, antes de abordar a discussão mais diretamente relacionada à mudança tecnológica, são apresentadas algumas questões acerca do programa de pesquisa evolucionário, também conhecido e denominado por alguns autores como não reducionista e sistêmico. Note-se que as propriedades globais deixam de ser concebidas apenas como o resultado da agregação individual, passando a ser definidas também a partir das suas propriedades relacionais, sendo, portanto, entendidas como sistemas.

Para Dosi \& Winter (2003), dentre as características utilizadas para descrever as teorias evolucionistas da mudança econômica, a dinâmica é apresentada como um "imperativo metodológico" compartilhado por todos os modelos.

A teoria evolucionária, a partir da sua análise dinâmica, busca fornecer a explicação para importantes fenômenos ao longo do tempo. Tais fenômenos distinguem-se pela manutenção e preservação de determinadas características do passado, o que significa dizer que as decisões tomadas no passado influenciam, em grande medida, as decisões de hoje; mas também envolvem elementos puramente aleatórios, não conhecidos pelos agentes, os quais, por sua vez, são responsáveis pela geração de variedade no sistema.

Dentre as demais características que definem o programa de pesquisa evolucionário, estão: 1) a consideração de que as teorias devem ser microfundamentadas, no sentido de que devem estar baseadas em relatos realistas sobre os agentes; 2) a necessidade de incorporar aspectos específicos da realidade, uma vez que teorias que lidam com abstrações e omissões geram interpretações erradas da realidade; 3 ) a hipótese de que os agentes possuem racionalidade limitada e, diante disso, interpretam de maneira imperfeita as informações do ambiente; 4) a existência de heterogeneidade entre os agentes, a qual é decorrente desse entendimento imperfeito do ambiente, e que se apresenta como dependente da traje- 
cessá-la integralmente. Esses agentes, por outro lado, procuram quando possível se adaptar às informações recebidas do meio e a partir disso agem para buscar soluções aos seus problemas. Mas cabe realçar que essas soluções não são perfeitas ou maximizadoras como no sentido neoclássico. Como aponta Prado (2006):

Nesse modo alternativo de pensamento microeconômico, as ações são pensadas como intencionais, mas elas têm sempre consequências não intencionais. Os agentes têm metas e procuram alcançá-las, mas não são senhores autocentrados no contexto da interação. (p.309)

Em decorrência da incerteza do meio, os indivíduos nessa abordagem são caracterizados como heterogêneos, parcialmente "cegos" e dotados de racionalidade limitada. São ainda vistos como seres mutáveis e adaptativos que aprendem e alteram suas expectativas quando necessário. Ademais, esses agentes, numa relação de reciprocidade com a sociedade, passam a ser, também, definidos por suas propriedades relacionais, além daquelas intrínsecas a eles (Prado, 2006).

Diante disso, as propriedades globais para a teoria sistêmica não podem ser obtidas por mera agregação das propriedades individuais, isto é, elas não podem ser meramente reduzidas às propriedades das partes, dado que os agentes não são independentes uns dos outros, encontrando-se organizados pelas estruturas sociais e, diante disso, formando composições que têm propriedades emergentes, o que significa dizer que elas formam propriedades que emergem como resultado das ações e interações desses indivíduos e, portanto, apresentam resultados que são imprevisíveis e não aditivos. Os todos econômicos são, consequentemente, "compreendidos como sistemas ou como composições globais, já que as interações que os constituem, constituem em processo também os próprios agentes enquanto tais" (Prado, 2006, p.305). Disso segue que o sistema, entendido como complexo, é determinado pelo indivíduo, mas esse sistema também determina em parte o comportamento desses indivíduos, uma vez que as ações e decisões que 
formam o todo geram consequências que retroagem sobre os indivíduos.

De acordo com Prado (2006), essa microeconomia denominada de sistêmica e evolucionária mostrou-se incompatível com o individualismo metodológico e com as hipóteses de maximização da microeconomia reducionista, uma vez que a primeira

exige que a explanação das propriedades macrossociais nesse campo do conhecimento seja remetida sempre à síntese entre propriedades individuais e relacionais, já que é exatamente isso que está implicado no conceito de sistema. Assim, o próprio comportamento individual é explicado em função de características psicológicas, posicionais, interativas, etc. do "indivíduo em sociedade", visto que nessa perspectiva, o indivíduo sem a sociedade é uma má abstração. (Prado, 2006, p.310)

Para Hodgson, as "partes e os todos, indivíduos e instituições, mutuamente constituem e condicionam um ao outro, rejeitando teorias de nível único em que as explicações de todos os fenômenos são empreendidas tendo em vista um tipo de unidade" (1999, p.138).

De maneira geral, é possível verificar, seguindo as proposições de Saviotti \& Metcalfe (1991), que, enquanto a teoria evolucionária está interessada no desenvolvimento de longo prazo e nas mudanças e descontinuidades geradas na estrutura econômica, a teoria ortodoxa está interessada nos estados de equilíbrio e em movimentos de curto prazo, os quais representam deslocamentos temporários em relação a posições estáveis e, portanto, não enfatizam, ou enfatizam pouco, a discussão sobre mudança estrutural e descontinuidades.

Segundo Hodgson (1999), a aproximação da economia com a biologia e as importantes contribuições da tradição de pesquisa biológica - oriundas do pensamento de Darwin e Lamarck - foi capaz de afastar a abordagem evolucionária do paradigma mecanicista que domina o mainstream. 
Nos trabalhos desenvolvidos por Darwin e Lamarck, vale destacar a importância dos conceitos de genótipo e fenótipo. Enquanto o primeiro diz respeito à configuração genética incorporada na estrutura do DNA, o fenótipo trata da configuração externa do organismo.

Darwin considera que os organismos transferem suas configurações genéticas para as gerações futuras, entretanto, não transferem aquelas características adquiridas no ambiente, ou seja, seu fenótipo. Pondera ainda que a mudança evolutiva ocorre devido a um processo de seleção natural no qual os indivíduos mais bem adaptados (ou as firmas mais lucrativas) são selecionados e transmitem sua estrutura genética aos descendentes, enquanto os menos adaptados tendem a ser eliminados.

A abordagem de Lamarck, assim como a de Darwin, considera que os organismos são afetados pelo meio ambiente em que estão inseridos, e que, a partir de alterações desse meio, eles desenvolvem variações para se adaptar às novas condições. Mas, de maneira diferente das proposições darwinianas, considera que tais características, isto é, tais adaptações desenvolvidas a partir das mudanças no meio, podem ser transmitidas aos descendentes.

Na abordagem evolucionária, os fenômenos econômicos, vistos como processos de mudança, no qual as capacidades e regras se modificam para se adequar a novos eventos ou superar problemas são semelhantes ao processo de seleção natural biológica.

Em tal abordagem, as rotinas e as regras de decisão, por sua vez, desempenham uma função similar aos genes e correspondem à configuração genética das firmas. E as mudanças econômicas realizadas por meio de buscas de novos processos e novos produtos por parte das firmas são semelhantes à mutação genética na biologia. Para essa abordagem, tanto a configuração genética como as características adquiridas podem ser transmitidas (Nelson \& Winter [1982]/2005).

Nas próximas seções procura-se discutir o processo de mudança técnica dentro dessa perspectiva evolucionária. 


\section{O tratamento evolucionário das inovações tecnológicas}

Grande parte da dificuldade da abordagem neoclássica em lidar com os processos de mudança tecnológica pode ser creditada ao caráter estático dessa teoria e, por conseguinte, à consideração de situações hipotéticas de equilíbrio. Outro fator limitante diz respeito à hipótese do comportamento maximizador e de racionalidade perfeita, já que a incerteza que permeia as inovações tecnológicas, o caráter irregular dessas mudanças e a diversidade de estratégias das firmas a torna irredutível à pura racionalidade (Nelson \& Winter, [1982]/2005). Como visto anteriormente, tais limitações conferiram um tratamento apenas secundário à questão da inovação por parte dos teóricos neoclássicos, e abriram espaço para o desenvolvimento de modelos de inspiração schumpeteriana, também conhecidos como neo-schumpeterianos ou evolucionários, os quais se mostraram bastante apropriados para estudar contextos que envolvem novidade permanente.

Os modelos neo-schumpeterianos ou evolucionários, diferente dos neoclássicos, substituem a análise estática e a hipótese de equilíbrio por uma análise dinâmica do processo e pela consideração de hipóteses de desequilíbrio em que as estruturas se desenvolvem ao longo do tempo. Substituem, ainda, a hipótese de comportamento racional e maximizador pela noção de incerteza.

Além do mais, o progresso técnico passa a ser enxergado como um instrumento de competição e como a principal fonte de crescimento e mudança estrutural numa economia, pois, de acordo com os evolucionários, as tecnologias e as estruturas industriais não estão delineadas como proposto pela abordagem neoclássica tradicional, segundo a qual, a partir da existência de um estoque de conhecimento tecnológico, as firmas facilmente avaliam, utilizam e reproduzem uma determinada tecnologia. De maneira diferente, essa abordagem considera que a tecnologia e as estruturas industriais estão sempre se desenvolvendo, e tal dinâmica é resultado do 
comportamento diferenciado das firmas, as quais podem apresentar características bastante específicas e particulares. ${ }^{21}$

As firmas, nesse sentido, tomam como base um conhecimento que está disponível, é de caráter público, ${ }^{22}$ e é compartilhado por todos os agentes envolvidos. Mas também procuram, a partir de novas buscas, ${ }^{23}$ melhorar e diferenciar seus procedimentos e estratégias, apresentando com isso diferentes formas de utilização dessas tecnologias no seu interior, fator que as distingue dos seus concorrentes e gera variações e evolução no sistema.

Além disso, parte-se do pressuposto de que a inovação, para a perspectiva evolucionária, caracteriza-se por envolver variedade, complexidade institucional, incerteza e diversidade de opinião dos indivíduos e organizações, que tenderão a formar opiniões diferentes com relação às políticas de $\mathrm{P} \& \mathrm{D}$. Ambientes que exibem inovação apresentam-se, portanto, em um contínuo estado de desequilíbrio, pois o processo de busca realizado pela firma a fim de introduzir inovações de processo e produto pode gerar diferentes reações no mercado. E essas diferentes reações podem ser tanto no que diz respeito à atuação dos seus concorrentes, uma vez que as consequências da criatividade humana e da mudança estrutural não predeterminada poderão ou não se limitar ao seu mercado, quanto no que se refere às respostas da sua demanda, dado que os consumidores podem apresentar diferentes avaliações sobre as características tecnológicas, afastando o sistema das posições de equilíbrio. Mas, mesmo atuando fora do equilíbrio, as firmas são vistas como sendo capazes de se adaptar às mudanças e estão numa

21. Esse caráter específico e particular relativo ao conhecimento lhe é atribuído tanto em função dos seus aspectos tácitos como também em função do uso de mecanismos de proteção de segredos e dispositivos legais como as patentes.

22. São exemplos as publicações científicas e técnicas.

23. De acordo com Nelson \& Winter ([1982]/2005, p.359), dentre as características que distinguem o processo de busca, estão: i) a irreversibilidade, ii) seu caráter contingente e dependência do que está para ser encontrado, e iii) sua incerteza fundamental. 
constante busca por novas estratégias, a fim de auferir lucros maiores.

Ao considerar que a introdução de inovações envolve a solução de problemas tecnoeconômicos, em que as consequências das ações presentes não podem ser plenamente antecipadas, pois dependem de acontecimentos e decisões que estão fora do seu alcance, a abordagem evolucionária abandona a hipótese de racionalidade perfeita.

Nessa abordagem, as decisões empresariais são, de maneira diferente, tomadas em um ambiente de incerteza para os agentes envolvidos, bem como para aqueles que são afetados pelo comportamento dos primeiros e, portanto, não podem ser baseadas em critérios de maximização de um objetivo bem definido sob condições plenamente delineadas, uma vez que as firmas não têm acesso livre e imediato a um número irrestrito de atividades produtivas e tampouco todos os processos estão sob o seu controle, passando a depender também das ações e decisões tomadas pelos outros agentes.

Nelson \& Winter (1977) partem do princípio de que as firmas procuram se comportar racionalmente, mas esse comportamento não deve ser traduzido em comportamento racional e maximizador da teoria microeconômica tradicional. Essa racionalidade, por outro lado, está relacionada ao conceito de "meio de seleção", o qual determina como o uso relativo de diferentes tecnologias se modifica ao longo do tempo. O comportamento dos agentes, nesse sentido, é determinado por um processo de seleção que, por sua vez, determina a direção da dinâmica, sendo representado de maneira procedimental e não por um cálculo de otimização. Desta feita, as escolhas passam então a ser expressas por meio de rotinas, que guiam e direcionam o comportamento da empresa na tomada de decisões, desempenhando um importante papel como memória organizacional. Desse modo, é esperado que as firmas se comportem no futuro de acordo com as rotinas que empregaram no passado. 
O termo rotina ${ }^{24}$ foi usado por Nelson \& Winter ([1982]/2005) para se referir aos padrões comportamentais que fossem, em certa medida, regulares e previsíveis. Diferente da abordagem ortodoxa que trata as técnicas produtivas disponíveis como conhecidas e dadas pelo mercado e, também, como sendo as melhores técnicas que maximizam o lucro da empresa, para a teoria evolucionária as técnicas produtivas refletem as rotinas, as quais direcionam as ações de uma empresa na tomada de decisões e as simplificam. Elas ainda reduzem o número de variáveis envolvidas e o custo no processamento, simplificando o cálculo envolvido e o processo de gerenciamento das decisões.

Nelson \& Winter ([1982]/2005) distinguem três classes de rotinas: i) as rotinas que governam o comportamento do curto prazo e não podem ser rapidamente alteradas, conhecidas como características organizacionais; ii) as rotinas relacionadas aos fatores de produção fixos no curto prazo, isto é, o estoque de capital da firma, e que determinam o comportamento de investimento; e iii) as rotinas que modificam as características operacionais, que, por sua vez, determinam como e quanto a firma produz sob várias circunstâncias. A conjunção desses fatores faz com que a prática, a repetição e os melhoramentos incrementais das rotinas tornem as firmas mais efetivas na exploração das oportunidades tecnológicas, o que acentua sua habilidade e seus conhecimentos específicos e eleva a sua eficiência organizacional.

Nesse ambiente de conhecimento imperfeito, as diversas firmas heterogêneas se empenham em aprimorar e diversificar a base tecnológica existente e, portanto, modificar as rotinas prevalecentes

24. Segundo Nelson \& Winter ([1982]/2005), as rotinas "incluem características das firmas que variam de rotinas técnicas bem especificadas para a produção de coisas, procedimentos para contratações e demissões, encomendas de novos estoques, ou aumentar a produção de itens de alta demanda, até as políticas relativas ao investimento, à pesquisa e desenvolvimento (P\&D) ou publicidade e estratégias empresariais relativas à diversificação da produção e ao investimento no exterior" (p.32-3). 
através da busca ${ }^{25}$ por novos processos, novos produtos e novas formas organizacionais, com o objetivo de aperfeiçoar essas técnicas e, a partir disso, extrair benefícios econômicos dessas inovações. ${ }^{26}$

As firmas que operam em diversos segmentos econômicos estão expostas a diferentes ambientes tecnológicos, segundo os quais algumas propriedades determinam o processo de busca inovativa. São elas: i) oportunidades tecnológicas, ii) apropriabilidade tecnológica, iii) cumulatividade do conhecimento tecnológico, e iv) natureza do conhecimento base (Dosi, 1988b). As diferentes especificidades e magnitudes dessas propriedades são, em parte, responsáveis pelas diferenças inter e intrassetoriais.

Quanto ao comprometimento de recursos com o processo de busca inovativa, este é, em parte, feito a partir da percepção por parte dos agentes da existência de diferentes oportunidades tecnológicas, as quais exibem características irreversíveis, específicas, cumulativas e dependentes da trajetória. É feito, ainda, a partir da percepção dos diferentes incentivos para a inovação quanto a retornos econômicos esperados e, também, em função da percepção das diferentes oportunidades econômicas (Dosi, 1988b).

As diferentes condições de oportunidades tecnológicas estão diretamente relacionadas com o desempenho das firmas, pois, quanto maiores forem essas oportunidades, melhores serão as possibilidades de aprendizado tecnológico e maiores serão as pressões sobre as firmas atrasadas. Esse é o processo de seleção que se estabelece e tende a gerar estruturas industriais bastante concentradas.

Mas, como assinala Dosi (1988b, p.1160),

A oportunidade é apenas uma condição necessária, mas não suficiente, para a exploração tecnológica concreta. [...] E [...] sua

25. No modelo de Nelson \& Winter ([1982]/2005), as buscas foram tratadas como P\&D.

26. As inovações consistem, em grande parte, em novas combinações de rotinas já existentes. 
exploração efetiva pelas empresas privadas dependerá de fatores como as condições de apropriabilidade e também das variáveis de mercado, tais como o tamanho do mercado, a elasticidade da demanda em relação ao preço e às mudanças na qualidade, e o grau de concentração industrial.

A apropriabilidade, nesse sentido, apresenta-se como uma propriedade do conhecimento tecnológico que viabiliza as inovações e as protege em graus variados das imitações dos seus concorrentes, garantindo os benefícios econômicos acumulados. As condições de apropriabilidade podem variar significativamente entre as indústrias e entre as tecnologias.

A apropriabilidade será baixa em condições em que o conhecimento é facilmente difundido e de fácil acesso. Nesses casos, as firmas imitadoras encontrarão facilidade em descobrir e duplicar os empreendimentos de uma firma inovadora. Em condições como essas, isto é, na falta de condições satisfatórias de apropriabilidade, as empresas teriam pouco incentivo para investir em inovação.

Por outro lado, a apropriabilidade será alta quanto maior for a dificuldade de imitação, isto é, quanto maior for a capacidade da firma inovadora de proteger a sua inovação. Nesses casos, apenas uma parte dos benefícios da inovação serão espalhados pelo sistema econômico. De maneira geral, é possível dizer que a existência dessas condições de apropriabilidade acaba por motivar os agentes a explorarem novas oportunidades tecnológicas. Os diferentes graus de proteção das inovações também apresentam características bastante divergentes entre as indústrias e entre as tecnologias, apresentando-se, portanto, como um fator importante para explicar a variância entre as mesmas.

Outro fator que determina o processo de inovação é a cumulatividade. Quanto maior a cumulatividade do progresso técnico, maiores serão as possibilidades de avanços tecnológicos. Verifica-se que o processo de busca é composto tanto por elementos estocásticos ou aleatórios como pelo conhecimento existente no ambiente em que a firma opera. E essa natureza do conhecimento cumulativo 
permite que as firmas utilizem a informação disponível no mercado com o objetivo de antecipar algumas mudanças que ocorrem no ambiente de seleção.

Essas variedades criadas no ambiente poderão ser transmitidas às gerações futuras e, diante disso, as organizações e tecnologias tenderão a mostrar continuidade no tempo, ${ }^{27}$ de modo que as realizações futuras estarão em grande parte relacionadas com o que fora feito no passado.

As firmas, entendidas como agentes que acumulam capacidades organizacionais, herdam a habilidade de introduzir transformações produtivas, incorporadas em regras e rotinas. Nesse contexto, as rotinas que funcionam como ordenadores de informação e dispositivos para armazenamento de conhecimento são vistas como hereditárias e selecionáveis. Elas são hereditárias porque o conhecimento presente nas rotinas não é descartado a partir da busca de novos conhecimentos, mas é acumulado e estocado na memória da firma, formando uma base de conhecimento que determina as buscas futuras.

As rotinas também são selecionáveis, pois é por meio do processo de seleção que as tecnologias e estratégias que se mostrarem melhores quanto a lucratividade e participação de mercado serão escolhidas ou então mantidas, e influenciarão o processo de mudança técnica, enquanto aquelas que se mostrarem inferiores serão descartadas ou alteradas. Cabe lembrar que é a motivação pela obtenção de lucros maiores e mais espaço no mercado que faz com que as firmas sejam estimuladas a introduzir novas mudanças no sistema, isto é, faz com que sejam estimuladas a empreender novos processos de busca.

O processo de seleção, nesse contexto, representa o mecanismo de validação e redirecionamento dos processos e resultados da busca. Vale notar que, nesse ambiente, a inovação é submetida tanto a um processo de seleção interna, realizado no interior da firma,

27. É nesse sentido que se diz que o comportamento (ou conhecimento) é irreversível e dependente da trajetória. 
como a um processo de seleção externa, que é dado pelo ambiente de competição do mercado, e, portanto, pela capacidade da firma de se destacar entre seus demandantes e rivais.

Em resumo, a teoria evolucionária vê a atividade inovadora como um constante processo de busca, descoberta, experimentação, desenvolvimento, imitação dos resultados alcançados pelas outras firmas, e adoção de novos produtos, novos processos e nova organização que visam melhorar as técnicas existentes (Dosi, 1988d). Esses processos inovativos, por sua vez, ocorrem a partir de formas e procedimentos que transformam ou criam novas atividades, isto é, novas rotinas. Em função disso, as firmas inovadoras desenvolvem um conjunto de ações cujas tarefas passam a ser determinadas por procedimentos rotineiros, que, por sua vez, são responsáveis pela determinação dos paradigmas tecnológicos.

\section{Os paradigmas tecnológicos}

Os paradigmas tecnológicos ${ }^{28}$ constituem um padrão de solução de diversos problemas tecnológicos específicos que são compartilhados pelas firmas, contendo indicações de quais direções as mudanças tecnológicas devem tomar e quais evitar. ${ }^{29}$ Os paradigmas

28. O conceito de paradigmas tecnológicos proposto pelos neo-schumpeterianos surge como uma tentativa de solucionar as limitações das concepções teóricas demand pull e technology push proposta pela teoria econômica convencional, segundo as quais as inovações são tratadas como um elemento exógeno ao sistema econômico. Enquanto para a noção demand pull a mudança técnica é determinada pelas forças do mercado, apresentando-se como um processo passivo e reativo, para a noção technology push é a própria trajetória da tecnologia, isto é, são os avanços científicos e as atividades de $\mathrm{P} \& \mathrm{D}$ industriais que conduzem ao progresso técnico. Para os autores neo-schumpeterianos, as duas teorias falham ao tentar explicar a mudança técnica e a inovação, pois não consideram que a inovação se apresenta como um processo simplesmente reativo, uma vez que as firmas estão sempre buscando melhorar suas tecnologias, independente dos sinais de mercado.

29. O conceito de paradigma tecnológico está próximo da definição de paradigma científico de Thomas Kuhn, já que ambos dizem respeito a uma visão de definição de problemas ou a um padrão de investigação. 
guiam as buscas e definem sobretudo as necessidades que devem ser sanadas, o conhecimento científico a ser utilizado na tarefa e também o material tecnológico a ser empregado. Portanto, os paradigmas tecnológicos definem as oportunidades tecnológicas ${ }^{30}$ para inovações subsequentes, bem como os procedimentos necessários para explorá-las, conduzindo os esforços para certas direções em detrimento de outras (Dosi, 1988d).

Esse padrão de solução de problemas está baseado em experiências passadas que são acumuladas ao longo do tempo, e também no conhecimento formal existente. ${ }^{31}$ Este oferece indicações em que os inventores podem se basear e conduz ao uso mais eficiente dos recursos destinados às atividades inovativas. Eis que essas atividades se apresentam como atividades fortemente seletivas, finalizadas em direções precisas e geralmente cumulativas na aquisição de capacitações para a solução de problemas, o que as afasta do conceito de tecnologia como informação, a qual é facilmente reproduzida e reutilizada e está livremente disponível (caráter público).

Mas vale notar, além das experiências passadas, que os paradigmas também envolvem capacitações que são específicas aos inventores, e que dependem de uma base de conhecimento privado e de características particulares, além das competências tácitas presentes no interior de cada firma e que não são facilmente copiadas (Dosi, 1988b).

De acordo com a presente perspectiva, o progresso técnico é inerente a um paradigma tecnológico, e a direção tomada pelo desenvolvimento tecnológico segue uma trajetória tecnológica que, por sua vez, constitui-se no modo de formular e solucionar determinados problemas tecnoeconômicos dentro do paradigma tecnológico.

30. Vale notar que os diferentes paradigmas tecnológicos implicam diferentes oportunidades para a inovação.

31. Esse conhecimento pode assumir característica privada, pública, codificada, simples, não padronizada, independente, específica, complexa, dependente, tácita, etc. 
Essas trajetórias tecnológicas tendem a exibir continuidade ao longo do tempo (path-dependent), pois as firmas são condicionadas pelas escolhas feitas no passado. Nesse sentido, as firmas tendem a continuar em uma determinada direção de busca, acentuando suas habilidades e conhecimentos específicos naquela atividade e auferindo retornos crescentes. Entretanto, quando a exploração das oportunidades no paradigma existente se torna decrescente e seus custos tornam-se elevados, novos avanços na ciência e tecnologia determinarão o aparecimento de novos paradigmas.

A comparação e a escolha entre diferentes paradigmas tecnológicos não envolvem apenas critérios objetivos, mas estão carregadas de incerteza, uma vez que as consequências das atividades inovativas não são conhecidas com antecedência, e também porque as empresas não conhecem todas as alternativas disponíveis. Essa seleção ou escolha, isto é, o estabelecimento de um paradigma tecnológico, dependerá, dentre outros fatores: das instituições que relacionam as pesquisas às aplicações econômicas, de fatores estritamente institucionais, de mecanismos de tentativa e erro, e, ainda, dos mecanismos de seleção via mercado (Dosi, 1988b, p.1136-7).

Diante da emergência de novos paradigmas, novos padrões de oportunidades de progresso técnico serão gerados nesse sistema, e tal efeito se espalhará para outras firmas e setores, que se beneficiarão dos avanços conquistados pelos primeiros, uma vez que serão geradas externalidades ${ }^{32}$ tecnológicas em todo o sistema econômico. Além disso, segundo Dosi (1988b), a emergência de novos paradigmas e a difusão de seus efeitos sobre a economia afasta as economias continuamente dos estados estacionários e evita o estabelecimento de retornos decrescentes no processo de busca por inovações.

Apesar desse ambiente de incerteza nas decisões tomadas, os autores evolucionários consideram que alguns aspectos, especificamente o tamanho da empresa ou a existência dos paradigmas tec-

32. Tais externalidades são geradas via fluxo insumo/produto e via complementaridades tecnológicas. 
nológicos, podem contribuir para aplainar tais "problemas", ou seja, são capazes de reduzir o grau de incerteza dos inovadores.

Em linhas gerais, é possível afirmar que a introdução de um paradigma tecnológico permite reduzir a incerteza fundamental ${ }^{33}$ que envolve o processo de busca pela inovação, dado que possibilita grandes incrementos nas capacidades de aprendizado das organizações empresariais na medida em que focaliza as direções das buscas e também auxilia na predição das atividades inovadoras. Nesse sentido, é possível afirmar que os paradigmas tecnológicos guardam uma estreita relação com as instituições, uma vez que eles são reproduzidos ao longo do tempo por meio do desenvolvimento delas (Dosi, 1988b).

Entretanto, a base de conhecimento preexistente e a capacidade de prever eventos ${ }^{34}$ não são consideradas perfeitas, caracterizando-se por ser incompletas, dado que são limitadas em sua cobertura e também porque as buscas realizadas pelas firmas estão sempre se alterando, o que afeta a avaliação das demais firmas e gera assimetrias entre elas (Saviotti \& Metcalfe, 1991).

Nesse sentido, os paradigmas e as trajetórias tecnológicos também poderão apresentar diferentes níveis de generalidade e características bastante distintas entre as diversas firmas e setores industriais, e isso porque a base de conhecimento existente possui um caráter público e universal, mas também um caráter privado, parcialmente tácito e específico, o que significa que parte do conhecimento científico é desenvolvido internamente e que, portanto, não pode ser inteiramente difundido. ${ }^{35}$

33. Segundo Dequech (1998), a incerteza fundamental é caracterizada pela possibilidade de criatividade e mudança estrutural não predeterminada.

34. Vale notar que esses mecanismos de aprendizado podem, no entanto, limitar as buscas das firmas, o que as conduz a uma inércia e resulta na adaptação imperfeita da firma.

35. Isso não significa, entretanto, que essas formas de conhecimento sejam inteiramente imóveis e não possam ser difundidas. Apesar da sua natureza local, cumulativa e específica, a atividade inovativa ou a informação pode se di- 
Portanto, são os diferentes incentivos específicos a cada firma ou setor, isto é, as diferentes condições de oportunidade e apropriabilidade, juntamente com as características específicas do conhecimento tecnológico, de natureza local e cumulativa e com os diferentes procedimentos de busca, ${ }^{36}$ que explicam as direções do avanço tecnológico e, portanto, a variedade ou os diferentes padrões de tecnologia observados nas diversas firmas e setores (Dosi, 1988b).

Além disso, as assimetrias geradas por inovações bem-sucedidas permitirão que as firmas se tornem mais competitivas do que as suas concorrentes, pois, quanto maiores forem essas assimetrias entre as firmas, maiores serão as oportunidades dos líderes tecnológicos de modificar a estrutura industrial em seu favor e melhorar o seu desempenho setorial (Dosi, 1988b).

Segundo Dosi, cada paradigma tecnológico (1988b, p.1131)

incorpora uma combinação específica de determinantes exógenos da inovação (e.g., os avanços universitários na ciência pura) e determinantes que são endógenos ao processo de concorrência e de acumulação tecnológica de firmas e indústrias particulares. Mais do que isso, cada paradigma envolve modos de busca, bases de conhecimento e combinações entre as formas de conhecimento tecnológico públicas e privadas que são muito específicos.

E são esses diferentes processos de busca, comportamento e estratégia das firmas as explicações para as diferenças de desempenho entre elas, assim como a sua capacidade de crescimento, ilustradas por sua parcela de mercado (market share), sua lucratividade e sua probabilidade de sobrevivência. Diante disso, as firmas que uti-

fundir. Entretanto, como assinala Dosi (1988b), a habilidade de replicar os resultados inovativos é bem mais rígida.

36. Segundo Dosi (1988b), enquanto, para algumas tecnologias, a inovação envolve pesquisas em laboratórios de $\mathrm{P} \& \mathrm{D}$ e diversos testes, para outras ela é mais informal e envolve melhoras incrementais nos projetos, sendo que nem sempre é percebida como resultado de investimento em $\mathrm{P} \& \mathrm{D}$. 
lizam as estratégias mais bem adaptadas irão crescer e aumentar a sua participação na economia, enquanto as empresas defasadas se empenharão em imitar as primeiras.

Vale lembrar que os processos de inovação são determinados pela própria trajetória natural da tecnologia, através da busca de novas oportunidades e pelas condições de apropriabilidade. São influenciados também pelos mecanismos de mercado, isto é, pelo julgamento do ambiente de mercado, ou demanda de mercado, expresso na expectativa das empresas sobre o comportamento das vendas e da rentabilidade. Esses mecanismos indutores determinados pelo mercado respondem pelos diferentes graus de comprometimento das empresas privadas com a geração de inovação, e são bastante relevantes na definição da busca por novos produtos e novas técnicas de produção. Diante de mudanças nas condições de mercado, as empresas são normalmente estimuladas a buscar novos produtos e novas formas de fazer as coisas.

Segundo Dosi (1988b), esses fatores, isto é, as diferentes condições de oportunidade e apropriabilidade,

juntamente com as condições que comandam a concorrência de mercado (e.g., os vários outros tipos de barreiras à entrada, escala mínima necessária, as dificuldades para fracionar ou ampliar mercados - tanto domésticos quanto externos -, a elasticidade de preço ou qualidade da demanda), determinam a evolução tanto do desempenho quanto das estruturas industriais. (p.1161)

Com isso, além do interesse na natureza e nos impactos de uma inovação sobre a produtividade da indústria, essa abordagem também está interessada na relação dessas inovações com a dinâmica industrial e com a estrutura de mercado, isto porque, além de gerar efeitos sobre a produtividade, o processo de inovação gera efeitos sobre a maneira como o mercado e a indústria se desenvolvem ao longo do tempo (Dosi, 1988b; Possas, 1989a). E é exatamente essa interação entre os mecanismos de mercado, por um lado, com as combinações entre as oportunidades, apropriabili- 
dades e a natureza do conhecimento, de outro lado, que determinam os diferentes padrões setoriais ${ }^{37}$ de mudança técnica observados.

Por fim, cabe ressaltar que, apesar da existência e da grande importância dos elementos considerados previsíveis utilizados para antecipar as mudanças que ocorrem no ambiente de seleção, nem todas as decisões empresariais serão rotineiras, devido à existência dos elementos específicos e dos elementos estocásticos. ${ }^{38}$

A existência de características específicas às firmas é responsável pelos diferentes graus de investimento em P\&D interfirmas e intrassetorial. Segundo Dosi (1988b), essas diferenças intersetoriais e intrassetoriais estão ligadas às características dos diferentes paradigmas tecnológicos e às formas pelas quais as capacitações inovativas se desenvolvem e podem ser competitivamente exploradas pelas firmas individuais. Nesse sentido, enquanto para algumas firmas e tecnologias o comprometimento de recursos com inovação envolve predominantemente uma atividade de busca formal, em geral realizada em laboratórios de $\mathrm{P} \& \mathrm{D}$, para outras, a atividade inovativa é mais informal e se origina de melhoras incrementais nos projetos, sendo que nem sempre é percebida como resultado de investimento em $\mathrm{P} \& \mathrm{D}$, pois estão internalizadas nas organizações,

37. Nessa linha, Pavitt (1984) desenvolve um estudo que tem como objetivo identificar diferentes grupos de indústrias conforme o seu padrão setorial de inovação. No estudo, o autor considera as possibilidades de oportunidades tecnológicas, geração de conhecimento e cumulatividade do conhecimento tecnológico, apropriabilidade tecnológica e tacitividade do conhecimento. E verifica que a presença diferenciada dessas propriedades nos grupos analisados proporciona distintas capacidades inovativas setoriais. O estudo procura mostrar que existem dinâmicas industriais diferenciadas em critérios de busca e seleção de inovação, formas de aprendizado, vínculo com a ciência, capacidade de proteção da inovação, relação de cooperação e interação entre firmas, etc., que resultam na impossibilidade de ocorrer um único padrão de inovação.

38. Como será visto mais adiante, Nelson \& Winter ([1982]/2005) reconheceram as possibilidades desses elementos estocásticos e imprevisíveis, ou seja, reconheceram a possibilidade de novidade genuína, entretanto, se depararam com a dificuldade de modelagem de situações como essa. 
sendo muitas vezes difícil auferir seus custos. Dentre essas formas de aperfeiçoamentos incrementais nas tecnologias estão as formas de aprendizado baseadas no learning by doing ${ }^{39}$ (aprender fazendo) e learning by using ${ }^{40}$ (aprender usando). Verifica-se ainda que, enquanto em alguns setores as inovações são geradas por grandes firmas, em outros também podem ser realizadas por firmas relativamente pequenas em relação ao mercado no qual operam (Dosi, 1988b).

E, por fim, verifica-se que algumas firmas que não investem em P\&D inovativa podem, por outro lado, estar empenhadas em imitar o que outras firmas estão fazendo a partir da adoção das inovações desenvolvidas por outras indústrias, isto é, elas estão realizando P\&D imitativo.

De forma geral, é possível concluir que os paradigmas tecnológicos ajudam a reduzir a incerteza fundamental da busca inovativa ao longo do tempo, porém essa incerteza nunca será completamente eliminada ex ante. As empresas que se defrontam com ambientes complexos e imprevisíveis tendem a adotar políticas estáveis e, a partir disso, reduzir a incerteza inerente à busca inovativa sem, contudo, eliminá-la.

Feitas essas considerações gerais acerca do programa de pesquisa evolucionário, em que se buscou destacar os principais pontos dessa abordagem, procurando diferenciá-la da abordagem neoclássica padrão, o capítulo que segue tem por objetivo identificar as principais características dos sistemas complexos, uma vez que essa abordagem apresenta algumas questões bastante similares e que estão bastante próximas da perspectiva evolucionária.

39. Esse tipo de aprendizado ocorre no interior da firma. Trata-se de um processo decorrente da própria atividade produtiva, pois, quanto maior a produção, maior será a experiência adquirida e melhor será o desempenho tecnológico da firma.

40. Aqui, a acumulação de capacidades decorre da utilização do produto, o qual, por sua vez, favorece o conhecimento dos problemas e qualidades deles, permitindo seu aperfeiçoamento. 



\section{2 \\ Os SISTEMAS COMPLEXOS}

\section{Origens}

A abordagem neoclássica padrão alcançou significativo espaço nas discussões de teoria econômica graças às suposições restritivas assumidas por esta, o que possibilitou a sua crescente formalização. Mas, ao mesmo tempo em que se apresenta como uma importante ferramenta de análise, tanto para modelos de competição perfeita quanto imperfeita, tal abordagem falha ao exigir simplificações e abstrações para a sua formulação, gerando modelos distantes da realidade empírica.

Seu interesse consiste em identificar os pontos de equilíbrio agregado resultantes das escolhas racionais individuais, e buscar trajetórias de equilíbrio resultantes, identificando aquelas mais eficientes ao longo do tempo. Contudo, não é capaz de descrever como esse mecanismo se altera ao longo do tempo nem leva em consideração a emergência de novas variáveis, padrões e estruturas que possam emergir como resultado da interação entre os agentes no sistema (Arthur, Durlauf \& Lane, 1997).

Colander (2000) argumenta que outras correntes de pensamento não conseguiram ganhar significativo espaço devido à incapacidade de promover essa formalização. Contudo, o domínio 
dessa abordagem se deu à custa de perdas no desenvolvimento do conhecimento econômico que levasse em conta suposições mais realistas, como a existência de indivíduos heterogêneos e dotados de racionalidade limitada, mas que possuem capacidade de aprendizado, ou ainda a questão da evolução das instituições.

É nesse contexto de limitação da capacidade da economia tradicional em fornecer respostas a importantes questões que se apresenta a necessidade de analisar métodos alternativos ao proposto pela teoria neoclássica padrão. Essa nova forma de pensar a economia, que ficou conhecida como abordagem dos sistemas complexos, vem apresentando importantes contribuições ao fornecer respostas para questões acerca do entendimento dos fundamentos econômicos das dinâmicas sociais. Tal abordagem desconsidera as hipóteses restritivas com que trabalha a economia tradicional, e representa uma alternativa no campo da ciência moderna, fornecendo ferramentas conceituais e de modelagem importantes para o entendimento do fenômeno complexo. ${ }^{1}$

Segundo Saviotti \& Metcalfe (1991), a termodinâmica fora do equilíbrio é aplicada aos sistemas abertos e não aos sistemas fechados típicos dos modelos teóricos neoclássicos. Com relação a esses sistemas, enquanto os sistemas fechados são caracterizados por não exibirem qualquer interação com o ambiente e tenderem a um estado de equilíbrio, nos sistemas abertos, as interações são possíveis, o que conduz a uma troca contínua de matéria, energia e informação com o ambiente. Diante da possibilidade de mudanças na estrutura e evolução dos sistemas, estes não tenderão a estados de equilíbrio, mas sim, eventualmente, a diferentes estados estacionários.

1. Essa abordagem considera questões como a existência de dependência da trajetória ( $p a t h$ dependency), tecnologia, retornos crescentes, racionalidade limitada, evolução e aprendizado, feedbacks positivos e equilíbrios múltiplos, questões essas, no geral, ignoradas pela visão neoclássica para que fosse possível tratar seus modelos, os quais, por outro lado, lidam com retornos decrescentes, equilíbrio estático e racionalidade perfeita. 
Apesar de conduzir a diferentes estados estacionários, verifica-se que o comportamento nesses sistemas abertos é caracterizado como irreversível, pois a base de conhecimento adquirida no passado influencia em parte o conhecimento futuro. Essa base se reflete em fenômenos dependentes da trajetória, ${ }^{2}$ o que se apresenta como uma situação que confere certa ordem a esses sistemas. Nessa abordagem, "a história importa e o acúmulo de 'pequenos' eventos aleatórios pode dar forma ao comportamento e às opções de escolha futuras de modo fundamental" (Saviotti \& Metcalfe, p.3).

Como já foi assinalado anteriormente, esses modelos questionam e abandonam a hipótese de agente econômico substantivamente racional da microeconomia neoclássica em favor de indivíduos sujeitos a um constante processo de aprendizado e adaptação, e, portanto, heterogêneos. Além disso, esses modelos lidam com a emergência de padrões de interação social ao longo do tempo, os quais se apresentam como resultado da interação não intermediada entre os agentes econômicos.

Segundo Arthur (2005), essa nova perspectiva representa uma maneira diferente de fazer economia que está baseada na modelagem computacional com base em múltiplos agentes (agent-based). ${ }^{3}$

O marco formal da aproximação da abordagem da teoria da complexidade com a ciência econômica foi a realização de um workshop, em 1987, que contou com a presença de economistas e físicos, e teve o objetivo de avaliar determinados fenômenos econô-

2. Arthur (1989) identificou esse fenômeno de path dependence no interior dos processos de inovação tecnológica, no qual as escolhas tecnológicas são condicionadas pelas escolhas feitas anteriormente. Assim, verifica-se que, quanto mais se investe num padrão tecnológico, tanto mais difícil se torna a passagem para um padrão alternativo. As empresas tenderiam a ficar "presas” (locked in) a uma determinada trajetória tecnológica.

3. Arthur (2005) assinala que essa nova abordagem tem sido identificada de diferentes formas: economia da complexidade, modelagem computacional, modelagem agent-based, economia adaptativa, pesquisa em economias artificiais, ciências sociais generativas. 
micos a partir da perspectiva da ciência da complexidade, cujas ideias estavam sendo amplamente discutidas nas ciências naturais. Os resultados foram significativos avanços da aplicação do conceito de complexidade no campo da economia, e a criação do Santa Fe Institute, nos Estados Unidos, no final da década de 1980 (Arthur, Durlauf \& Lane, 1997).

A teoria dos sistemas complexos vem se desenvolvendo em várias áreas de investigação científica. Vale dizer que ela é mais antiga e desenvolvida em outros campos das ciências do que na economia. Mas alguns pesquisadores dessa abordagem, como Colander (2000) e Foley (2003), sustentam que a ideia de complexidade já estava presente em alguns autores, sendo possível encontrar elementos dessa abordagem em seus escritos.

Desse modo, apesar de a economia ser formalmente relacionada à abordagem dos sistemas complexos apenas no final da década de 1980, é importante notar que muitos economistas, anteriores ao surgimento dessa abordagem, já reconheciam a possibilidade de interação entre os agentes e a sociedade na economia. Entretanto, esses autores ainda não dispunham das ferramentas necessárias para o tratamento quantitativo dessa modelagem. Diante dessa limitação, verifica-se que, apesar de reconhecerem a importância dos mecanismos de interação social, qualquer esforço de formalização sempre acabava restrito à análise estática da economia padrão e, portanto, a abstrações muitas vezes não condizentes com a realidade.

Para Colander (2000), a análise desses sistemas dinâmicos complexos tornou-se possível apenas a partir do desenvolvimento da tecnologia computacional, sendo que "muitos economistas podem ter tido a perspectiva da complexidade, mas eles não a seguiram no seu trabalho formal porque não tinham as ferramentas para fazê-lo" (p.34). Assim, apesar de considerarem questões importantes, dentre as quais algumas são tratadas pela economia da complexidade - como a existência de retornos crescentes e equilíbrios múltiplos -, diante de tais limitações, esses economistas 
tória; 5) a capacidade dos agentes de se adaptar e descobrir novas tecnologias e novas organizações e, também, de adotar novos padrões de comportamento, caracterizando um sistema que exibe novidade permanente; 6) as interações coletivas dentro e fora dos mercados operam como mecanismos de seleção; 7) o resultado dessas interações fora do equilíbrio e do aprendizado heterogêneo são fenômenos agregados caracterizados como propriedades emergentes; 8) as instituições e as formas organizacionais também apresentam propriedades emergentes, dado que também expressam um resultado não intencional das interações coletivas fora do equilíbrio e do aprendizado heterogêneo; 9) as instituições, regras e formas organizacionais apresentam certas regularidades que, diante disso, restringem e dão forma ao processo evolucionário (Dosi \& Winter, 2003, p.387-8). ${ }^{19}$

Quanto ao ambiente evolucionário, ele envolve um processo de aprendizado e descoberta imperfeita, o que conduz a uma adaptação subótima do meio. De maneira geral, o ambiente é visto como um sistema complexo que passa por mutações e carrega incerteza, mas que é capaz de se adaptar e de se auto-organizar. Contudo, o conjunto de escolhas não é conhecido e dado como na abordagem reducionista, ${ }^{20}$ de tal modo que as consequências das decisões dos agentes tornam-se desconhecidas.

A capacidade computacional e cognitiva dos agentes, ao contrário do que se pressupõe na teoria neoclássica, que parte da hipótese de racionalidade perfeita, é limitada e, portanto, as decisões tomadas não podem ser consideradas maximizadoras, mas apenas satisfatórias. Portanto, a informação existe parcialmente, mas os agentes, que possuem informação imperfeita e estão em um constante processo de mudança, não são capazes de captá-la e pro-

19. Os autores consideram, entretanto, que nem todos os modelos evolucionários compartilham todos esses blocos de construção teórica, mas limitam-se à consideração de apenas alguns deles.

20. O problema na abordagem reducionista consiste apenas em selecionar as melhores produção e distribuição possíveis dentro do conjunto de alternativas. 
ficavam restritos à análise estática da economia padrão e faziam abstrações muitas vezes distantes da realidade.

Foley (2003) identifica o ponto de vista da economia política sobre o fenômeno da auto-organização como uma importante perspectiva metodológica. Segundo o autor, a aceitação do fenômeno da auto-organização "permite que os economistas políticos investiguem a dinâmica de estruturas autorreprodutíveis na vida econômica, sem projetá-las impropriamente no nível microssocial relativo ao comportamento das famílias e das empresas" (p.11). É nesse sentido que acredita ser possível identificar características dos sistemas complexos no campo dos economistas políticos clássicos e em Marx, de modo que tal avaliação se torna relevante.

Em sua tentativa de identificar a contribuição de autores individuais de determinadas correntes de pensamento, Colander (2000) verifica que uns se aproximam mais do que outros da abordagem dos sistemas complexos.

Especificamente no que tange à obra de Smith, tanto Colander (2000) como Foley (2003) identificam elementos da abordagem dos sistemas complexos. Enquanto Colander (2000) chama a atenção para a questão dos retornos crescentes, Foley (2003) destaca a discussão de Smith acerca da gravitação clássica, em que os preços de mercado tendem a gravitar em torno dos preços naturais nos quais as taxas de lucro poderiam ser equalizadas.

De acordo com essa visão, os capitalistas fluem setorialmente, transferindo investimentos de determinadas atividades econômicas para outras, em busca de taxas de lucro superiores. Tal processo ocorre até que os ganhos dos capitalistas sejam equalizados, o que implica a existência de um processo auto-organizado do sistema econômico competitivo.

Cabe lembrar que Smith considera que as

taxas comuns ou médias podem ser denominadas taxas naturais dos salários, do lucro e da renda da terra, no tempo e lugar em que comumente vigoram. Quando o preço de uma mercadoria 
não é menor nem maior do que o suficiente para pagar ao mesmo tempo a renda da terra, os salários do trabalho e os lucros do patrimônio ou capital empregado em obter, preparar e levar a mercadoria ao mercado, de acordo com suas taxas naturais, a mercadoria é nesse caso vendida pelo que se pode chamar seu preço natural. (Smith, 1996, p.111)

É a partir dessa concepção de taxa natural que o autor elabora o seu arcabouço teórico - que leva em consideração as complexas relações de produção, distribuição e consumo - com o objetivo de descrever o que se denomina mercado auto-organizado, cujo mecanismo está descrito no trecho seguinte.

Quando a quantidade de uma mercadoria colocada no mercadoé inferior à demanda efetiva, não há possibilidade de fornecer a quantidade desejada a todos aqueles que estão dispostos a pagar o valor integral - renda da terra, salários e lucro - que deve ser pago para colocar a mercadoria no mercado. Em consequência, ao invés de desejar essa mercadoria ao preço em que está, alguns deles estarão dispostos a pagar mais. Começará imediatamente uma concorrência entre os pretendentes, e em consequência o preço de mercado subirá mais ou menos em relação ao preço natural, na proporção em que o grau de escassez da mercadoria ou a riqueza, a audácia e o luxo dos concorrentes acenderem mais ou menos a avidez em concorrer. [...] Por outro lado, [...] se em algum momento a quantidade posta no mercado superar a demanda efetiva, algum dos componentes de seu preço deverá ser pago abaixo de sua taxa natural. (Smith, 1996, p.111)

Percebe-se, então, que o mecanismo elaborado por Smith implica uma condição de autoequilíbrio, uma vez que todos os componentes do preço chegarão à sua taxa natural, de tal modo que o preço integral será o próprio preço natural. Ou seja:

o preço natural é como que o preço central ao redor do qual continuamente estão gravitando os preços de todas as mercadorias. 
Contingências diversas podem, às vezes, mantê-los bastante acima dele, e noutras vezes, forçá-los para baixo desse nível. Mas, quaisquer que possam ser os obstáculos que os impeçam de fixar-se nesse centro de repouso e continuidade, constantemente tenderão para ele. (Smith, 1996, p.111-2)

O capitalista nessa perspectiva é visto como um benfeitor público e a mão invisível smithiana é a representação desse sistema que se autorregula. Foley (2003), ao considerar a mão invisível de Smith como uma representação do funcionamento de um sistema que se autorregula, afirma que o arcabouço smithiano é compatível com a teoria dos sistemas complexos, auto-organizados e que funcionam fora do equilíbrio.

A obra de Malthus também apresenta características que são compatíveis com a economia da complexidade. Mais especificamente, essa aproximação é observada em seu estudo sobre equilíbrio demográfico, cuja análise se centra num mecanismo de feedback estável, dado que, quando a taxa de mortalidade é menor do que a taxa de fertilidade, a população tende a crescer.

Entretanto, na visão daquele autor, a produção de alimentos não cresce na mesma proporção, e sim a taxas decrescentes, elevando então a taxa de mortalidade. Segundo Malthus, o equilíbrio entre a produção e o consumo anuais pode levar as nações à prosperidade ou à decadência. Isso porque:

Se em determinados períodos a produção de um país excede seu consumo, os meios de aumentar seu capital poderão ser obtidos, sua população logo crescerá, ou então essas grandezas se ajustarão melhor, e provavelmente ambas as coisas ocorrerão. Se em tais períodos o consumo é exatamente igual à produção, não haverá nenhum meio para aumentar o capital e a sociedade será quase estacionária. Se o consumo excede a produção, em cada período subsequente a sociedade será mais mal abastecida, e sua prosperidade e população declinarão. (Malthus, 1996, p.33-4) 
Verifica-se que, nesse esquema proposto pelo autor, as ações dos indivíduos não são intencionais, uma vez que não é possível prever as consequências das suas decisões de fertilidade nem se esta resultará em um equilíbrio demográfico.

Já a avaliação acerca da contribuição de Ricardo apresenta algumas divergências entre os autores que procuraram estabelecer relações entre ele e a abordagem dos sistemas complexos. Para Foley (2003), o estado estacionário, para o qual tenderia a economia capitalista em função do rendimento marginal decrescente da terra, proposto por Ricardo, apresenta-se como um estado auto-organizado de um sistema que se adapta e muda. Tal perspectiva pode ser avaliada no trecho abaixo. Para Ricardo (1996), se

existisse terra fértil em quantidade muito maior do que a requerida para a produção de alimentos para uma população crescente, ou se o capital pudesse ser aplicado indefinidamente na terra antiga sem retornos decrescentes, não poderia haver elevação da renda, pois esta procede invariavelmente do emprego de uma quantidade adicional de trabalho com um retorno proporcionalmente menor. [...] Mas como [...] As terras mais férteis e mais favoravelmente localizadas serão cultivadas primeiro, e o valor de troca de seus produtos será ajustado da mesma forma que o de todas as demais mercadorias, isto é, pela quantidade total de trabalho necessário, sob várias formas, da primeira à última, para produzi-los e colocá-los no mercado. Quando a terra de qualidade inferior começa a ser cultivada, o valor de troca dos produtos agrícolas aumenta, pois torna-se necessário mais trabalho para produzi-los. (p.52-3)

Como consequência desse quadro, a taxa de lucro dos capitalistas tende a ser reduzida, até que alcance um determinado nível que os leva a interromper as suas respectivas atividades produtivas, conduzindo a economia ao chamado estado estacionário.

Para Foley, esse estado estacionário apontado por Ricardo 
não vem a ser um equilíbrio microeconômico em que os agentes se põem voluntariamente, mas um estado auto-organizado de um sistema complexo que continuamente se adapta e muda. $\mathrm{O}$ estado estacionário é um resultado macroeconômico gravitacional. (2003, p.5)

Colander (2000), por outro lado, argumenta que a busca de Ricardo por um sistema de equilíbrio único conduziu a uma simplicidade estrutural que o afasta da abordagem dos sistemas complexos.

Nos trabalhos de Marx, tanto Foley (2003) quanto Colander (2000) identificaram elementos da abordagem da complexidade. Segundo Foley (2003), Marx

procurou descobrir regularidades agregadas na economia capitalista que não dependessem apenas do comportamento detalhado dos indivíduos. [...] Além disso, Marx [...] pôde alcançar conclusões analíticas fortes e gerais sobre o desenvolvimento econômico capitalista sem se limitar a modelos particulares e implausíveis. (Foley, 2003, p.5)

O tema é polêmico, mas Foley (2003, p.6) argumenta que a introdução por Marx, na economia política, da linguagem da dialética pode ser entendida como uma tentativa de encontrar uma linguagem precisa para discutir o fenômeno dos sistemas complexos e da auto-organização.

Associada a essa linguagem, Marx desenvolveu a concepção materialista da história para explicar o modo de produção tipicamente capitalista, que, segundo Foley (2003), apesar de apresentar uma característica de auto-organização dos sistemas, encontra-se em desenvolvimento constante.

Cabe ressaltar, ainda, que essa concepção desenvolvida por Marx representa o seu método de fazer "economia política", e evidencia, acima de tudo, como as relações de produção são complexas quando avaliadas por esse enfoque. Tal afirmativa pode ser corroborada na passagem a seguir: 
Quando estudamos um país dado do ponto de vista da economia política, começamos por sua população, a divisão desta em classes, seu estabelecimento nas cidades, nos campos, na orla marítima; os diferentes ramos da produção, da exportação e a importação, a produção e consumo anuais, os preços das mercadorias, etc. Parece mais correto começar pelo real e o concreto, com o pressuposto efetivo; assim, pois, por exemplo, na economia, pela população, que é a base e o sujeito de todo o ato social de produção. Todavia, bem analisado, este método seria falso. A população é uma abstração se deixo de lado as classes a que compõe. Estas classes são, por sua vez, uma palavra vazia se ignoro os elementos sobre os quais repousam, por exemplo: o trabalho assalariado, o capital etc. Estes supõem a troca, a divisão do trabalho, os preços etc. (Marx, 2003, p.410-1)

É nesse sentido que Marx (2003) propõe a sua forma distinta de fazer ciência, que, ao inverter a ordem de análise, parte do abstrato para o concreto, de tal modo que as determinações abstratas, ou as partes que compõem o fenômeno analisado, levam à reprodução do concreto por meio do pensamento.

De maneira geral, Foley considera que a auto-organização é independente do modo de funcionamento particular das partes, uma vez que "tendem a continuar funcionando mesmo se algum dos seus subsistemas deixa de funcionar" (2003, p.5). O autor considera que os sistemas complexos são determinados, uma vez que

é possível relacionar as interações dos milhares de componentes ao comportamento agregado, [...] mas o mesmo não é predeterminado [...] no sentido de que é impossível descobrir o caminho exato que percorre no seu processo de desenvolvimento. (2003, p.6)

Ainda segundo Foley (2003), é nesse ponto que reside a principal diferença entre os sistemas de equilíbrio e os sistemas complexos, uma vez que o primeiro tende a regressar a estados considerados 
predeterminados, enquanto os últimos experimentam evolução e finais abertos.

\section{Principais características}

A perspectiva da complexidade, de maneira diferente da economia neoclássica padrão, procura utilizar fundamentos mais abrangentes e flexíveis para analisar a realidade econômica, e introduz questões como: a possibilidade de interação direta entre agentes heterogêneos e dispersos pelo sistema, a inexistência de um controlador global absoluto, a existência de diversos níveis de organização hierárquica, a possibilidade de adaptação contínua entre os agentes que acumulam experiências, e, por fim, a renovação constante dos processos produtivos que conduz a economia para fora do equilíbrio (Arthur, Durlauf \& Lane, 1997).

Nicolis \& Prigogine (apud Wible, 2000) desenvolveram um trabalho sobre complexidade no campo das ciências naturais do qual é possível extrair importantes aplicações dessas ideias na sociedade. Os autores argumentam que durante três séculos a história da ciência seguiu a teoria newtoniana, na qual as leis do universo eram vistas como reversíveis e deterministas. Porém, diante da incapacidade de fornecer respostas para importantes questões, os cientistas passaram a considerar que as leis do universo são estocásticas e irreversíveis, uma vez que na realidade se verifica que o mundo exibe diversidade, evolução e instabilidades, e desse modo pode estar longe dos estados de equilíbrio.

Assim, de maneira diferente do reducionismo dos mecanismos newtonianos, que reduz os fenômenos complexos de maneira completa, objetiva e determinista, os sistemas complexos implicam pluralismo, multiplicidade e coexistência de diferentes fenômenos, tornando qualquer reducionismo impossível, já que são sistemas compostos por unidades interagindo, e exibem propriedades emergentes que não podem ser meramente reduzidas às propriedades das partes. 
Apesar disso, são sistemas capazes de se auto-organizar e criar novos padrões de atividades e estruturas, influenciando o comportamento de outros agentes. Tais sistemas são vistos como sistemas dinâmicos que tanto podem se manter (sistemas conservadores) como podem se desenvolver ao longo do tempo (sistemas dissipadores).

Segundo Wible (2000), os sistemas dinâmicos complexos requerem novas concepções de ordem além de equilíbrio. Assim, esses sistemas podem se caracterizar como sistemas mecânicos, situação na qual o equilíbrio ocorre quando todas as forças do sistema somam zero, e desse modo o equilíbrio é atingido sem que haja perda de energia. Esse sistema pode ainda ser um sistema não mecânico, situação na qual uma ordem ou padrão é definido como steady state e, nesse estado, o movimento não é padronizado, mas sim aleatório e móvel; e por fim também é possível que os sistemas complexos estejam em estados bastante distantes do equilíbrio e nesses estados a auto-organização de novos padrões pode emergir.

De acordo com essa abordagem, é mais provável que a economia esteja fora do equilíbrio, e tal característica permite que esses modelos lidem com mudança e variedade e, consequentemente, com sistemas capazes de gerar inovações, os quais não tenderão a estados de equilíbrio.

Apesar da consideração da existência de ordem e regularidade, ou ainda da emergência de estruturas organizadas, na abordagem agent-based, a possibilidade de mudança constante no sistema e também a possibilidade do surgimento de comportamento perpetuamente novo e criativo afastam a economia do steady state. Nos casos em que o equilíbrio é possível, pode haver mais do que um padrão de consistência, conduzindo a uma situação de múltiplos equilíbrios no sistema (Arthur, 2005).

Esses modelos estocásticos formados por entidades que interagem entre si podem ser executados em computador e, a partir disso, torna-se possível extrair regularidades agregadas ou estruturas organizadas que, na maioria das vezes, estão em condições bastante distantes do equilíbrio. A modelagem tem por principal 
objetivo descobrir as propriedades emergentes desses sistemas. Desse modo, como argumenta Foley (2003):

A teoria da complexidade representa um ambicioso esforço para analisar o funcionamento de sistemas descentralizados, mas altamente organizados, compostos por um número muito grande de componentes individuais. (p.1)

Algumas características permitem identificar a economia como um sistema complexo, dentre as quais o fato de haver a interação de inúmeros indivíduos que apresentam um comportamento heterogêneo, inteligente e adaptativo, que lhes permite reagir às mudanças que ocorrem ao seu redor. Trabalham com a possibilidade de interação entre os agentes componentes, os quais são capazes de se desenvolver e se adaptar ao ambiente, que está em constante mudança, gerando com isso novos padrões de auto-ordenamento e estruturas emergentes (Foley, 2003).

Nesse sentido, esses padrões de auto-ordenamento não resultam apenas do agregado das partes, mas também da interação entre elas, e,

são ditos emergentes, porque se manifestam em um nível hierárquico superior àquele das interações que os ocasionam, e porque embora decorram da ação e da interação de suas partes, não decorrem da intenção das mesmas em configurá-los no agregado; isto é, ainda que o todo dos sistemas complexos pareça ter uma dinâmica própria de lógica irredutível, ele não é o produto de qualquer projeto de cooperação deliberada e implementada pelos agentes para aquele fim, mas um resultado espontâneo, imprevisto e não intencional, cujo comportamento decorre igualmente da conjunção dos processos de adaptação e interação de seus elementos. (Freitas, 2001, p.15)

A possibilidade de interação entre os agentes faz com que as ações, estratégias e expectativas de uns estejam relacionadas e dependam das ações, estratégias e expectativas de outros agentes. 
Segundo Arthur (2005), tais movimentos, isto é, tais interações, são sempre realizados na expectativa de algum resultado, que pode ser determinado coletivamente, o que significa que depende dos resultados das ações de outras pessoas.

Em casos como este, os agentes procuram prever o resultado que será alcançado, mas suas ações baseadas em suas previsões determinam esse resultado. Então a situação é autorreferencial: ${ }^{4}$ os agentes estão tentando formar expectativas sobre um resultado que se apresenta como função das suas expectativas. Ou, para ir além disso, suas escolhas de expectativas dependem das suas próprias escolhas de expectativas. (Arthur, 2005, p.7)

Vale notar que tais interações não são reguladas por um controlador global, mas são mediadas por instituições, regras e associações que estão sempre se alterando de tal modo que seus comportamentos e estratégias são revisados, e mudanças estruturais são introduzidas ao longo do tempo conforme os agentes adquiram novas experiências. Com isso é possível dizer que esses sistemas estão em constante processo de evolução, e a consideração dessa estrutura dinâmica conduz a economia para fora do equilíbrio.

Disso segue que a abordagem da complexidade está interessada em entender como o comportamento se ajusta conforme a situação

4. Um exemplo de autorreferência é o problema do Bar El Farol desenvolvido por Arthur(1994). Nesse modelo, as pessoas precisam decidir se vão ou não a um bar que tem uma capacidade máxima de cem pessoas, mas que consegue acomodar de maneira confortável e oferecer bons serviços quando há no máximo sessenta. Portanto, sessenta pessoas é a frequência desejável. Nesse modelo, os agentes tomam suas decisões de frequência com base nos seus processos cognitivos (que são limitados). A partir disso, eles formulam as suas expectativas de quantos agentes irão comparecer. Os agentes alteram seu comportamento quando suas expectativas que funcionam como regras de comportamento conduzirem a resultados ruins, isto é, a uma situação em que o bar esteja vazio ou cheio demais. Dessa forma, o resultado final depende do próprio comportamento dos agentes, mas também depende do que os agentes imaginam ser o resultado final e por isso se diz que a situação é autorreferencial. 
se desenrola, isto é, está interessada no processo e não apenas no resultado ou no equilíbrio. Ademais, essa abordagem possui uma visão pluralista na qual os agentes são dotados de capacidade cognitiva limitada, uma vez que habitam um mundo que está em constante processo de evolução. Assim, não é possível dizer que os agentes otimizam no sentido padrão, mas eles se adaptam e aprendem e com isso adquirem experiências que lhes permitem escolher a melhor ação possível, e, de acordo com Arthur, Durlauf \& Lane (1997, p.10), "esse processo de aprendizado e influência acontece por meio de redes de interação social nas quais os agentes estão embutidos".

Enquanto na análise do equilíbrio geral os agentes não interagem diretamente, mas apenas por meio de mercados impessoais, na perspectiva da complexidade, as estruturas baseadas em redes se tornam importantes, de tal modo que toda ação econômica envolve interação entre os agentes, e tais ações são estruturadas por regras sociais emergentes e por instituições.

Bowles (2004) desenvolve uma análise cujo interesse é explicar como os indivíduos $e$ as instituições interagem para produzir resultados agregados ao longo do tempo. Para tanto, considera diferenças na experiência histórica, nas instituições e no comportamento.

Segundo o autor, as interações econômicas e sociais entre os indivíduos não são sempre reguladas por contratos completos, como sugere a abordagem tradicional, sendo bastante frequentes interações não contratuais que não possuem como resultado um equilíbrio. Nesse contexto, os indivíduos que são heterogêneos e versáteis possuem interesses diferentes, mas são capazes de se adaptar às diferentes situações. E é a partir das suas experiências passadas e do seu conhecimento adquirido ao longo do tempo que eles agem em busca de seus objetivos.

Ainda segundo Bowles (2004), essas interações econômicas e sociais conduzem a feedbacks positivos, os quais são bastante sensíveis às condições iniciais, uma vez que pequenas alterações nessas condições geram um resultado bastante diferenciado, tornando o 
resultado do sistema imprevisível e de difícil monitoramento. Disso segue que, na presença desses feedbacks, pode haver mais do que um estado estacionário, cujos múltiplos estados de equilíbrio podem ser deslocados apenas através de choques exógenos.

Como visto anteriormente, dentre os objetivos da economia computacional agent-based está entender como o equilíbrio é formado ou ainda como a economia se comporta fora do equilíbrio, situação na qual deve ser vista como: um processo dependente da trajetória (path-dependent), o que implica que os resultados atuais do sistema dependem de resultados anteriores; orgânico, isto é, cuja mudança afeta as propriedades dos seus componentes; e evolutivo, o que significa que está em constante desenvolvimento (Arthur, 2005).

A economia deve ainda ser vista como um processo emergente, o que significa dizer que as propriedades agregadas não são uma mera reflexão das propriedades das unidades constituintes do sistema, o qual se auto-organiza e gera novos padrões a partir disso.

Em economias fora do equilíbrio, as propriedades orgânicas criam padrões que influenciam o comportamento dos agentes. Segundo essa concepção, os agentes estão em um constante processo de aprendizado e, diante de mudanças no meio, seu comportamento será modificado; com isso, certos padrões econômicos que garantiam o equilíbrio da economia podem se modificar, afastando a economia do steady state (Arthur, 2005). A modelagem agent-based supera, assim, a preocupação reducionista com a estabilidade do equilíbrio, sem negar, com isso, a ocorrência de padrões ou regularidades.

Dada a complexidade dos fenômenos econômicos, esses sistemas são de difícil previsão. Além disso, devido às interações não lineares, estocásticas e de difícil previsão desses sistemas, torna-se difícil expressar o resultado das interações matematicamente, isto é, a partir do uso das técnicas analíticas tradicionais, uma vez que são sistemas imprevisíveis e incontroláveis. Em ambientes como esse faz-se, portanto, necessária a utilização de técnicas de modelagem computacional baseadas no agente, que permitem a análise 
do comportamento fora do equilíbrio e, portanto, a construção de modelos mais realistas.

Tais simulações são capazes de extrair (prever) as regularidades (padrões) que governam esses sistemas que são vistos como auto- organizados, adaptativos e funcionando de modo não equilibrado. E tais processos, gerados em computadores, imitam os processos econômicos da vida real.

Segundo Arthur, Durlauf \& Lane (1997), os sistemas que apresentam as propriedades descritas anteriormente, caracterizados como sistemas complexos que se desenvolvem, passaram a ser chamados de redes não lineares adaptativas, e uma característica importante dessas redes é que os agentes formam expectativas, criam modelos e tomam decisões com base nas previsões geradas por esses modelos.

Esses estudos agent-based estão bastante próximos da abordagem evolucionária e tal aproximação decorre do fato de que essa abordagem compartilha uma visão distinta de mundo, no qual os agentes operam. Nessa perspectiva, os "agentes diferem na maneira que reagem a padrões agregados; têm diferentes particularidades, diferentes histórias e diferentes psicologias. Isto é, os agentes são adaptativos e heterogêneos" (Arthur, 2005, p.3). Mais especificamente, no que concerne às discussões acerca de inovação e mudança tecnológicas feitas pela abordagem da simulação baseada no agente, verifica-se que grande parte desses estudos foram iniciados e têm sido conduzidos a partir do trabalho de Nelson \& Winter ([1982]/2005), o qual é capaz de lidar com simulações computacionais. Mas, como será visto mais adiante, teóricos posteriores foram capazes de ampliar as fronteiras de pesquisa e de introduzir novas técnicas de modelagem.

Entretanto, na visão de Colander (2000), a economia da complexidade, quando segue as diretrizes do Instituto Santa Fé, está mais próxima da economia padrão ${ }^{5}$ do que das escolas de pensa-

5. Aqui vale destacar que Colander não está defendendo que a abordagem dos sistemas complexos tenha se desenvolvido da abordagem padrão. 
mento heterodoxas, apesar de estas últimas fornecerem muitos dos seus argumentos para a economia da complexidade. $\mathrm{O}$ argumento do autor em favor da maior proximidade da economia da complexidade com a economia padrão está relacionado ao foco de ambas na matemática e na formalização científica. E isto porque, como visto anteriormente, a abordagem tradicional busca, a partir da estrutura estática linear, simplificar a estrutura. A abordagem dos sistemas complexos tem um objetivo similar, isto é, identificar padrões em estruturas simplificadas, mas aqui, diferentemente, como foi visto, essa análise é feita em modelos dinâmicos não lineares e o instrumento de análise é a modelagem computacional.

Apesar da consideração da existência de ordem e regularidade, ou ainda da emergência de estruturas organizadas nesses sistemas, existe a possibilidade de sistemas genuinamente novos e criativos que podem configurar o aparecimento de novas espécies, isto é, o aparecimento de novidades no sistema ou de novos padrões de comportamento. E diante da possibilidade da existência de "novidade genuína", esses sistemas passam a ser modelados como se exibissem certos padrões previsíveis, já que são limitados a uma fronteira na qual não é possível gerar novas dimensões. Tal forma de determinação estocástica é considerada limitada, uma vez que, diante de uma situação em que haja "novidade genuína", a ação humana pode conter elementos de indeterminação e, portanto, ser de difícil previsão (Hodgson, 1999, p.143). Essa dificuldade de incorporar novidade genuína pode ser apresentada como uma das limitações desses modelos, mas não é capaz de tirar a importância dessa abordagem para o estudo dos fenômenos que envolvem inovações.

\section{Instrumentos teóricos}

Em sistemas complexos, caracterizados como dinâmicos e não lineares, as respostas às mudanças observadas no meio variam em 
diferentes escalas e intensidades, devido à presença de feedbacks positivos e negativos, podendo gerar diferentes resultados no sistema, pois, na presença de feedbacks positivos e negativos, os efeitos não são proporcionais à suas causas. Enquanto os primeiros ampliam o efeito das flutuações tornando o sistema imprevisível, os feedbacks negativos reduzem esse efeito, tornando o sistema mais estável, porém incontrolável. Portanto, interações nos sistemas complexos caracterizam-se como imprevisíveis e incontroláveis (Heylighen, 2008).

Diante da consideração de que os indivíduos interagem e de que estão conectados, é possível afirmar que mudanças em determinado período de tempo e local influenciarão as mudanças em outros tempos e locais, mas, devido à presença de feedbacks positivos e negativos, é difícil prever essa influência e, portanto, o efeito da implementação de determinadas ações (Heylighen, 2008).

Além disso, devido à particularidade dos resultados, não é possível estabelecer qualquer propriedade geral a respeito dessas interações e padrões criados. Portanto, a multiplicidade de graus de liberdade e autorreferências dificulta a previsão e a estabilidade e apresenta-se como um problema para esses sistemas. Todavia, Foley (2003) considera ser possível identificar as relações que causam a auto-organização e a partir disso formular leis tendenciais.

A teoria dos sistemas complexos, nesse sentido, apresenta-se como uma alternativa aos modelos deterministas tradicionais que admitem total previsibilidade dos resultados, e como um importante instrumento de análise. De maneira diferente, propõe que os parâmetros do modelo e as propriedades dos agentes podem ser modificados como resultado de sua interação. Essa teoria utiliza métodos altamente empíricos e indutivos e em função disso busca construir modelos particulares, simplificados e abstratos a partir da interação de inúmeros componentes em simulações computacionais. Tal método tem o objetivo de identificar as propriedades de adaptabilidade e auto-organização que são características desses sistemas. Busca, com isso, identificar como os padrões que 
emergem a partir da interação desses indivíduos são formados (Foley, 2003).

Apesar da dificuldade de prever o resultado das interações e dos padrões criados, haja vista que o sistema está em constante processo de desenvolvimento, é possível extrair algumas considerações gerais, ou regras a respeito das ações dos agentes nessa estrutura. Essas regras determinam o comportamento dos agentes e podem ser transformadas ou ainda combinadas com as regras de outros agentes e procuram poupar energia. Esse processo se dá através da coevolução entre os agentes, os quais tendem a escolher as melhores preferências, isto é, aquelas que lhes fornecem os melhores resultados e, portanto, o menor gasto de energia, em detrimento das menos favoráveis que, por outro lado, tendem a ser eliminadas.

Vale dizer que, dada a possibilidade de interação, as escolhas de determinados agentes irão influenciar na escolha e decisão de outros, e é nesse sentido que é possível dizer que interação exibe sinergia. Como assinala Heylighen (2008), o alcance desse estado sinergético resultante da interação entre os agentes consiste num processo de tentativa e erro ou variação e seleção. E acrescenta Heylighen:

Para explorar os possíveis comportamentos do sistema, muitos caminhos diferentes - com diferentes condições iniciais ou variações aleatórias durante o processo - da simulação são desempenhados. Esses valores são analisados estatisticamente para descobrir tendências recorrentes. [...] Na maioria dos casos, os resultados podem ser classificados em um número relativamente pequeno de categorias distintas. $\mathrm{E}$ isso fornece aos pesquisadores uma figura qualitativa dos resultados mais prováveis - $e$ uma compreensão dos fatores que promovem um resultado em vez de outro. [...] E o que faz os sistemas complexos tenderem a um determinado arranjo dentro de um grupo relativamente pequeno de comportamentos identificáveis é a sua tendência inerente à auto-organização. (Heylighen, 2008, p.5) 
Um exemplo a ser utilizado mais adiante consiste na adoção por determinada empresa de uma inovação tecnológica que se mostra produtiva e rentável. Verificar-se-á que, diante da possibilidade de interação, tal ação pode se mostrar atrativa para outras empresas, poupando o gasto de energia das demais empresas que, por sua vez, tenderão a seguir medidas atrativas antes implementadas pela primeira.

O objetivo dos agentes nesses sistemas não é meramente maximizar a utilidade individual, mas minimizar o atrito e as fricções e maximizar a sinergia, reduzindo assim a instabilidade do sistema (Heylighen, 2008). Não são, portanto, indivíduos egoístas como sugere a abordagem tradicional, mas sim cooperadores. Ademais, diante da dificuldade de previsão, as ações são testadas ou mesmo escolhidas aleatoriamente, e aquelas que se mostrarem mais estáveis e adaptadas serão mantidas e multiplicadas, enquanto as instáveis serão descartadas. Elas podem ainda ser alteradas por aprendizado. Vale dizer que esse processo é semelhante à seleção natural biológica.

Em sistemas complexos auto-organizados, as interações locais resultam em coordenação global e sinergia e afetam o sistema como um todo. Aqui, a estrutura global tem propriedades emergentes e, portanto, não é uma mera composição das partes individuais, mas sim um processo coletivo que depende das interações dos indivíduos componentes, os quais se encontram conectados, motivo pelo qual são continuamente afetados pelas decisões dos demais agentes no sistema, uma vez que a ação de um agente gera reflexos sobre os demais. De acordo com Heylighen, "os agentes codesenvolvem, um se adapta ao outro, até que eles se ajustam mutuamente" (2008, p.7). A estrutura que emerge da auto-organização pode ser representada como uma rede complexa que conecta os agentes e exibe propriedades de grupo.

Heylighen (2008) assinala ainda que esse processo de interação e coordenação local gera organização global. Isto significa dizer que, quando os agentes alcançam um "estado ajustado", se define uma "construção estável” que outros agentes desejarão alcançar, 
aumentando assim o tamanho dessa construção estável e desejável até que ela abarque o sistema global e afete o sistema como um todo. O autor cita como exemplo os processos de organização física que compreendem agentes idênticos ou similares com objetivos e desejos também similares no qual a solução de um agente tende a satisfazer a de outro, resultando em uma estrutura global uniforme e regular.

Por outro lado, em sistemas complexos imprevisíveis, incontroláveis e compostos por agentes heterogêneos, como o caso do ecossistema ou em um mercado, "cada um precisa explorar uma ordem para encontrar seu único espaço em um meio que continua a se desenvolver" (Heylighen, p.7). Como visto anteriormente, diante da possibilidade de interação, o comportamento de uns agentes, influenciará o comportamento de outros seguindo um processo parecido com a seleção natural, uma vez que as interações sinergéticas são preferíveis às outras.

Essas interações estabilizadas podem, segundo Heylighen (2008), ser chamadas de "laço, relação ou elo", e as diferentes interações sinergéticas constituem uma rede complexa que tem diferentes particularidades e exibe características específicas que são definidas estatisticamente, isto é, certas características aparecem com uma probabilidade maior do que outras.

Foley (2003) aponta que os sistemas complexos e sua tendência à auto-organização podem ser modelados por meio de equações diferenciais, que matematicamente têm como ponto de repouso um equilíbrio. Entretanto, o autor aponta para a existência de uma distinção entre os conceitos de auto-organização e equilíbrio e, também, para a existência de várias noções de equilíbrio, dentre as quais se destaca a de equilíbrio termodinâmico, que denota equilíbrio no nível macro mesmo que o sistema esteja constantemente em mudança e haja desequilíbrios no nível micro.

Segundo o autor, essa noção de equilíbrio termodinâmico tem alguma semelhança com a auto-organização de um sistema complexo, mas difere da abordagem econômica tradicional, uma vez 
que nesta última é o equilíbrio no plano individual, ou seja, no nível micro que garante o equilíbrio no agregado (macro), o que implica uma entropia nula.

Apesar de o equilíbrio termodinâmico ser um raciocínio próximo da abordagem dos sistemas complexos, Foley (2003) sustenta que a auto-organização

não pode ocorrer em um sistema dinâmico estável, o qual tende a colapsar todas as estruturas em um estado de equilíbrio estável. Auto-organização também é insustentável em um sistema localmente instável [...] Assim, [...] estruturas auto-organizadas são características de sistemas que não são matematicamente nem localmente estáveis nem localmente instáveis, os quais podem favorecer e reproduzir estruturas identificáveis ao longo de grandes períodos de tempo. (Foley, 2003, p.9)

A auto-organização dos sistemas complexos, portanto, consiste num processo de coevolução e sinergia, o que os distancia da abordagem neoclássica, na qual a entropia é nula, e dos equilíbrios termodinâmicos, nos quais a entropia é máxima. Esses sistemas, de maneira diferente, consideram que existe perda de energia, mas essa perda não é máxima, e o objetivo dos indivíduos consiste justamente em diminuir essa perda de energia.

Assim, é possível dizer que os sistemas complexos estão situados entre a ordem da abordagem tradicional e a desordem do equilíbrio termodinâmico, pois não são nem plenamente regulares e previsíveis nem aleatórios e caóticos, exibindo uma mistura das duas dimensões, já que é possível verificar certos padrões regulares nessa estrutura (Heylighen, 2008).

\section{Economia computacional}

Para o estudo de sistemas econômicos dinâmicos que exibem assimetria de informação, competição imperfeita, interação entre 
os agentes, informação limitada, aprendizado e a possibilidade de equilíbrio múltiplo se faz necessário o uso de ferramentas computacionais. Para Axelrod \& Tesfatsion (2005), a modelagem baseada no agente (ABM) aplicada a processos sociais utiliza conceitos e ferramentas da ciência social ${ }^{6}$ e da ciência computacional. Tal proposta também ficou conhecida como ACE (Agent-based Computational Economics).

Esse método é apropriado para estudar sistemas dinâmicos compostos por agentes que interagem e sistemas que exibem propriedades emergentes, isto é, propriedades que surgem das interações das unidades e que não podem ser reduzidas à mera agregação das partes. Em situações como essa - em que o resultado da interação é incerto e na qual os agentes se adaptam continuamente-, a análise matemática encontra limites para derivar consequências dinâmicas, de tal modo que a modelagem ACE se apresenta como um método mais eficaz.

Segundo Tesfatsion (2005), em modelos desse tipo, os agentes devem ser livres para se comportar de acordo com as suas convicções, preferências, instituições e circunstâncias físicas, as quais podem variar ao longo do tempo. Além disso, na modelagem ACE existe a possibilidade de aprendizado que também pode variar com o tempo e, com isso, os diversos agentes podem ter diferentes visões sobre o mundo:

os microagentes repetidamente se empenham em interações locais, produzindo regularidades globais [...] Essas regularidades globais se regeneram em direção à determinação das interações locais. O resultado é um complexo sistema de laços de regeneração interdependentes que conecta comportamentos micro, padrões de interação e regularidades globais. (Tesfatsion, 2005, p.4)

6. O interesse da ciência social é entender como os indivíduos se comportam e interagem e ainda como essa interação conduz a resultados agregados (Axelrod \& Tesfatsion, 2005). 
Nesse tipo de modelagem, o modelador ACE constrói computacionalmente um mundo econômico que inclui múltipla interação de agentes e observa o desenvolvimento desse mundo ao longo do tempo. Tal método "inicia com hipóteses sobre os agentes e suas interações e então utiliza a simulação de computador para gerar histórias que são capazes de revelar as consequências dinâmicas dessas hipóteses" (Axrelrod \& Tesfatsion, 2005, p.2).

O estado inicial de um sistema econômico é então especificado pelo modelador a partir dos dados iniciais dos agentes, dos seus métodos comportamentais e do grau de acessibilidade desses dados e métodos aos outros agentes. Como assinala Tesfatsion (2005), alguns desses dados e métodos comportamentais são publicamente acessíveis a todos os agentes, enquanto outros são privados e há, ainda, aqueles que são protegidos do acesso de outros agentes. E é a partir desses métodos públicos e protegidos que os agentes podem se comunicar uns com os outros.

Vale destacar, novamente, que nesses sistemas não existe a figura de um planejador central como na abordagem tradicional; apesar disso, é possível extrair padrões e regularidades a partir das interações entre os agentes e esse método permite aumentar o entendimento sobre os sistemas.

Segundo Tesfatsion (2005, p.8), os dados dos agentes devem incluir:

seu tipo de atributo (mundo, mercado, firma, consumidor); seus atributos estruturais (geografia, desenho, função custo, função utilidade) e ainda a informação sobre os atributos dos outros agentes.

O método do agente, por sua vez, deve incluir:

métodos comportamentais institucionalmente constituídos (leis antitruste, protocolos de mercado), assim como métodos comportamentais privados (produção e estratégia de preço, algo- 
ritmos de aprendizado para atualização de estratégias) e métodos para métodos que são variáveis (como exemplo, métodos para se mover de um algoritmo de aprendizado para outro). Isto significa que $[. .$.$] o modelo ACE resultante deve ser dinamicamente$ completo $[\ldots]$, o que significa que o sistema econômico modelado deve ser capaz de se desenvolver sozinho ao longo do tempo, apenas sobre as bases das interações dos agentes, e sem intervenções do modelador. (Tesfatsion, p.8)

Uma das vantagens da modelagem ACE em relação à abordagem padrão é que admite a possibilidade de aprendizado e comunicação entre os agentes. Além disso, o agente aqui possui mais autonomia, isto é, maior capacidade de aprendizado, do que o da abordagem padrão. Essas capacidades incluem diversas habilidades, dentre elas: a habilidade de comunicação social, a habilidade de aprendizado com base na experiência dos outros, a habilidade de formação e manutenção de padrões de interação social, a habilidade de desenvolvimento de percepções compartilhadas, a habilidade de alterar preferências como resultado da aprendizagem, e, por fim, a habilidade de exercer controle ao longo do tempo (Tesfatsion, 2005, p.11).

Essas características de flexibilidade, autonomia e robustez do processo de auto-organização criam padrões e estruturas que são distribuídas por todo o sistema e permitem que os sistemas complexos se desenvolvam e se adaptem a meios em mudança.

Ao desconsiderar as hipóteses restritivas com que trabalha a abordagem padrão e fornecer ferramentas conceituais e de modelagem que permitam a análise do comportamento fora do equilíbrio, a teoria dos sistemas complexos mostrou-se bastante apropriada para discutir o processo de inovação tecnológica, fornecendo um entendimento mais satisfatório e mais condizente desses fenômenos.

Entretanto, esses modelos requerem a construção de modelos econômicos dinamicamente completos e especificações iniciais detalhadas para os dados dos agentes, além de métodos que deter- 
minem seus atributos estruturais, arranjos institucionais e disposições comportamentais. De acordo com Arthur (2005), isso encoraja hipóteses comportamentais que são ad hoc, e, diante disso, alguns pressupostos são adaptados apenas por conveniência, o que significa que os modelos são ajustados para encaixar os fatos estilizados estabelecidos pela teoria. Um estudo didático de sociedades artificiais desenvolvido por Epstein \& Axtell (1996), em Growing artificial societies, mostra que o potencial explanatório dessa técnica é bastante grande.

O capítulo que segue tem como principal objetivo identificar as principais características que permitem pensar o processo de inovações tecnológicas dentro dessa perspectiva, assim como apresentar algumas das limitações que não foram resolvidas. 



\section{3 \\ O PROCESSO DE INOVAÇÃO TECNOLÓGICA DE UMA PERSPECTIVA AGENT-BASED}

É possível discutir o processo de inovação e mudança tecnológicas a partir da utilização da ferramenta da modelagem baseada no agente (ABM ou ACE), a qual é capaz de lidar com questões bastante complexas por meio de simulações computacionais. Tais discussões têm encontrado significativo espaço e grandes vantagens quando analisadas nesse contexto teórico.

Ao lidarem com simulações computacionais, os modelos ACE são capazes de relacionar as estratégias de inovação com a estrutura de mercado e com outras variáveis como a produtividade, o número de firmas e o crescimento econômico.Grande parte desses trabalhos sobre inovação tecnológica que utilizaram a modelagem ACE foi desenvolvida com base na linha de pesquisa da economia evolucionária iniciada por Nelson \& Winter ([1982]/2005), abordagem esta que é capaz de lidar com simulações computacionais como uma útil ferramenta de análise dos processos dinâmicos e, por isso, tem sido fundamental para os trabalhos ACE sobre inovação (Dawid, 2006).

Antes de partir mais detalhadamente para essa relação e influência do modelo desenvolvido por Nelson \& Winter ([1982]/2005) para o método ABM, torna-se importante destacar 
algumas características do processo de inovação tecnológica que justificam essa análise, bem como a utilização dessas ferramentas.

Nos modelos da teoria evolucionária da mudança econômica e em modelos de economia artificial, o sistema está em constante processo de evolução e desenvolvimento, o que lhe impossibilita atingir um equilíbrio ou um estado próximo disso. Pois, mesmo nesses modelos, a velocidade com que uma inovação é adotada é maior do que a velocidade da adaptação. Por meio deles, estudam-se as propriedades transitórias do sistema, ou os desequilíbrios, uma vez que tais eventos implicam que os parâmetros estão sempre se alterando.

A novidade gerada nos processos evolucionistas carrega características do passado, mas também contém aspectos puramente imprevistos ou aleatórios. Eé essa segunda característica que, segundo Dosi \& Winter (2003), dificulta a modelagem do fenômeno de inovação, pois implica uma explosão no número de dimensões do espaço explorado pelo sistema. Diante dessa dificuldade,

uma estratégia de modelização possível consiste então em projetar um hipotético espaço de busca multidimensional sem especificar completamente a "lei de movimento" desse espaço, exceto localmente. (Dosi \& Winter, 2003, p.393)

Em construções como essa, ou seja, que exibem novidade persistente, o sistema não tenderá a um equilíbrio, mas, por outro lado, em tais dinâmicas abertas

podem-se encontrar regularidades relativas a processos que se apoiam, eles próprios, em propriedades emergentes, estruturas metaestáveis, padrões temporais de eventos (do tipo "pontuação" de quase-equilíbrios e grandes descontinuidades estruturais) ou ainda propriedades dinâmicas médias (tais como a taxa de crescimento de certas variáveis). (Dosi \& Winter, 2003, p.393) 
Ainda segundo Dosi \& Winter, a simulação, seguida pelas economias artificiais e também por alguns modelos que se apoiam nas teorias evolucionárias da mudança econômica,

oferece a oportunidade de explorar de modo experimental e quantitativo o comportamento de convergência do modelo, sempre recorrendo às evidências brutas ou à intuição para atribuir valores aos parâmetros. (2003, p.394)

Para Dawid (2006), a abordagem ACE fornece uma melhor compreensão do processo de mudança tecnológica e é capaz de incorporar os aspectos e as características das inovações em seus modelos. Dois argumentos justificam a utilização dessa abordagem no tratamento das inovações tecnológicas: 1) a sua maior capacidade em lidar e incorporar em seus modelos as propriedades genuínas do processo de inovação e mudança tecnológica, e 2) a incapacidade dos modelos neoclássicos de equilíbrio padrão de fornecer explicações aos fatos empiricamente estilizados. Esses dois argumentos são apresentados com mais detalhes nas seções seguintes.

\section{Propriedades do processo de inovação}

Dawid (2006) aponta para a existência de quatro propriedades genuínas que caracterizam o processo de inovação e mudança tecnológica: i) estrutura dinâmica do processo; ii) natureza especial do conhecimento; iii) incerteza substantiva forte envolvida; e iv) a importância da heterogeneidade.

Segundo o referido autor, o processo de inovação não gera efeitos apenas sobre a produtividade da indústria, mas também sobre a maneira com que o mercado e a estrutura da indústria se desenvolvem ao longo do tempo, motivo pelo qual os aspectos dinâmicos do processo devem ser levados em conta. Considera-se 
que as estruturas industriais não estão delineadas como propõe a abordagem padrão, mas, por outro lado, elas estão em contínuo desenvolvimento e tal dinâmica é o resultado dos comportamentos diferenciados das firmas, as quais apresentam características bastante específicas e particulares.

Dawid (2006) chama a atenção para a estrutura de tempo existente na trilogia invenção-inovação-difusão de novas tecnologias da obra de Schumpeter. E disso segue que a maneira com que esses processos tomam forma está intimamente relacionada com a dinâmica industrial e com as estruturas de mercado.

Outra característica da inovação diz respeito à natureza especial do conhecimento. Essa característica se apoia na ideia de que o sucesso de uma inovação depende tanto dos investimentos correntes como da estrutura de conhecimento acumulado pela firma ao longo do tempo. Ora, este não é uniforme, uma vez que pode apresentar diversas estruturas, isto é, ele pode ser público ou privado, explicito ou tácito e, ainda, geral ou específico. Nesse sentido, é possível afirmar que as ações correntes e o sucesso das inovações dependem em grande medida das experiências passadas ou do conhecimento acumulado ao longo do tempo, de modo que as ações futuras também serão, em grande medida, influenciadas pelas experiências passadas.

Seguindo a avaliação feita no segundo capítulo, para entender o contexto de inovações tecnológicas dentro da teoria dos sistemas complexos torna-se importante estudar os conceitos de retornos crescentes, lock-in e path dependence, que foram abordados por autores como Arthur (1989) e David (1985). Essas expressões foram usadas para argumentar que a história importa, e isso porque a existência de determinadas tecnologias deve ser explicada pela história de sua criação, adoção e desenvolvimento.

A realização das atividades tecnológicas de forma contínua e repetitiva gera acúmulo de conhecimentos, de habilidades e aumenta a experiência das empresas ao longo do tempo, o que eleva a sua capacidade de explorar novas oportunidades em direções específicas e amplia o incentivo para fazê-lo também no futuro. Os 
inventores são, portanto, direcionados às tecnologias que já apresentam grandes avanços acumulados, isto é, eles serão direcionados às tecnologias mais bem desenvolvidas. ${ }^{1}$

Esse fenômeno trata do conceito de path dependence, segundo o qual as escolhas econômicas são, em grande medida, condicionadas pelas escolhas feitas anteriormente. Diante disso, as tecnologias se tornam dominantes em função dos retornos crescentes dinâmicos de escala acumulados.

O estudo dos processos de acumulação de conhecimento dentro da empresa é bastante diferente do estudo dos processos de acumulação de capital físico devido sobretudo ao seu caráter tácito e específico, o que permite que a informação seja apenas parcialmente comercializada no mercado. Diante disso, apenas parte do conhecimento desenvolvido internamente será difundido. Entretanto, caso o conhecimento seja compartilhado entre vários agentes econômicos, ocorrerão retornos crescentes dinâmicos e lock in.

De forma geral, verifica-se que parte do conhecimento que está embutido nos indivíduos, ou em um grupo de indivíduos, pode fluir em direção a canais locais e globais de difusão, de tal sorte que o estudo desses fluxos de conhecimento conduz a "discussões de interação local e formação de rede de comunicação" (Dawid, 2006, p.1238). Consequentemente, redes de desenvolvimentos se formam em torno da melhor tecnologia, criando as condições necessárias para o seu melhor aproveitamento.

Dentre os mecanismos de acumulação de conhecimento destacam-se: in-house $\mathrm{P} \& \mathrm{D}$, que é o mecanismo informal de transferência de conhecimento entre as companhias (spillovers), e o learning by doing (Dawid, 2006).

Outro importante evento a ser destacado é que os diferentes processos de inovação geram externalidades tecnológicas para outras firmas ou setores. Desse modo, as experiências, qualificações, capacitações e memórias acumuladas em determinadas empresas

1. Vale notar que, nas tecnologias menos desenvolvidas, grandes avanços ainda precisam ser alcançados para que se tornem competitivas. 
ou setores acabam transbordando de uma atividade para outra. Elas são, portanto, internalizadas nas atividades das firmas e acabam gerando melhoras de desempenho nessas empresas e na economia como um todo.

No entanto, tal forma de inter-relacionamento também pode conduzir a fenômenos de histerese, na medida em que conduz a uma inércia ou a um aprisionamento no conhecimento de velhas competências, restringindo a busca pela aquisição de novas capacidades. E isso ajuda a entender por que empresas ou países ficam presos (locked in $)^{2}$ a determinadas tecnologias.

Segundo Dosi (1988b, p.1148),

Tais formas de retornos crescentes dinâmicos específicas à tecnologia tendem a "aprisionar" o processo de mudança tecnológica em trajetórias particulares, impondo um reforço mútuo (um feedback positivo) entre um certo padrão de aprendizado e o padrão de alocação de recursos em atividades inovativas nas quais o aprendizado já ocorreu no passado.

A geração de externalidades positivas ou de externalidades de rede acaba afetando o comportamento dos mercados, pois os fatores que conduzem a retornos crescentes estão geralmente entrelaçados ao processo envolvido no desenvolvimento de tecnologias cumulativas.

2. O formato de teclado QWERTY, inventado para evitar o emaranhamento das teclas das máquinas de escrever é um exemplo de um padrão ineficiente que persistiu ao longo do tempo e tornou-se modelo padrão principalmente devido à familiaridade dos datilógrafos experientes e também à existência de programas de treinamento de digitação desse método. A manutenção desse tipo de padrão de teclado nos computadores, mesmo sem o problema do emaranhamento das hastes, está relacionada a um processo path dependent, o qual, por sua vez, decorre principalmente do fato de esse padrão de teclado ter sido inventado primeiro, já que o seu sucesso não teria qualquer relação com a sua eficiência. E a persistência desse padrão em detrimento de outros formatos alternativos que podem ter se mostrado melhores (Dvorak) está relacionada ao conceito de lock in, isto é, ao aprisionamento à tecnologia devido a sua maior difusão no mercado. 
Eé essa natureza cumulativa do conhecimento, que é, em parte, difundida no mercado, o fator que permite às firmas antecipar mudanças que ocorrem no ambiente, e o que explica em parte o caráter relativamente ordenado dos padrões observados de mudança tecnológica.

Dawid (2006) destaca que diversos estudos empíricos apontam para a relevância dos spillovers tecnológicos, que representam um fluxo de conhecimento entre firmas ou indivíduos dependendo principalmente dos próprios esforços de $\mathrm{P} \& \mathrm{D}$ dentro das firmas. Todavia, o autor destaca que os estudos que utilizam a estrutura de Nelson \& Winter ([1982]/2005) como referência não consideram a acumulação dinâmica de uma base de conhecimento estruturado por parte das firmas que competem no mercado. Nessa estrutura, por outro lado,

A acumulação de conhecimento é tratada assumindo que todo o conhecimento corrente usado está incorporado na tecnologia corrente usada, ou ainda pela consideração de uma variável estoque de $\mathrm{P} \& \mathrm{D}$ que é elevada por investimentos ao longo do tempo. [...] A utilização de simulações agent-based permite ao modelador adicionar algumas estruturas empiricamente relevantes ao modelo padrão de acumulação de conhecimento e spillovers. (Dawid, 2006, p.1249)

Dentre os estudos desenvolvidos ${ }^{3}$ pela abordagem agent-based acerca da acumulação de conhecimento e spillovers estão o de Cantner \& Pyka (1998), o de Ballot \& Taymaz (1997) e o de Gilbert et al. (2001). No modelo desenvolvido por Cantner \& Pyka (1998), a probabilidade de uma inovação ser bem-sucedida depende tanto do estoque de capital em P\&D quanto do tamanho do spillover, o

3. Vale observar que não é objetivo deste livro discutir de maneira detalhada os modelos que trataram as propriedades genuínas dos processos de inovação de uma perspectiva agent-based, mas apenas apresentar aspectos gerais a que chegaram esses modelos, os quais foram apresentados de maneira mais detalhada em Dawid (2006). 
qual, por sua vez, dependerá da capacidade de absorção da firma, da qualidade do produto e da posição relativa da firma na indústria. Nesse modelo, os autores concluem que as firmas que interagem com as demais e acumulam capacidade absortiva são mais rentáveis do que aquelas que levam em conta apenas o seu próprio estoque de P\&D.

O modelo de simulação desenvolvido por Ballot \& Taymaz (1997) apresenta uma conclusão similar ao modelo anterior. As firmas nesse modelo constroem estoques de habilidades específicas e, diante disso, aumentam seu estoque de conhecimento, elevando a probabilidade de inovações radicais bem-sucedidas. $\mathrm{O}$ modelo aponta para a existência de uma relação estatística positiva entre o investimento da firma em conhecimento geral e a taxa de lucro, o que leva Ballot \& Taymaz a enfatizar a importância de os investimentos em $\mathrm{P} \& \mathrm{D}$ serem precedidos pela construção de um conhecimento geral.

E, por fim, no modelo de simulação desenvolvido por Gilbert et al. (2000, 2001), esses autores buscaram desenvolver uma forma de modelar o conhecimento e as capacidades com mais detalhe. Diante de tal proposta, procuraram estudar não apenas o aumento em um montante de conhecimento, mas também a identificação dos diferentes padrões de acumulação de conhecimento existentes.

Voltando à discussão sobre as propriedades do processo de inovação, a terceira, que envolve a incerteza substantiva forte, leva em consideração o fato de que em ambientes baseados em tais condições não é possível prever as invenções que serão feitas nem antecipar os resultados da implementação de certa inovação, já que o agente não conhece todos os resultados possíveis de um projeto de inovação, em função de sua capacidade computacional e cognitiva ser limitada, fato que o torna incapaz de encontrar uma solução ótima num problema de escolha.

Tal qual foi destacado anteriormente, na abordagem agent-based, as firmas são guiadas por diferentes estratégias de busca por inovações, isto é, elas estão continuamente empenhadas em uma busca open-ended por novos objetivos, ou meios em mudança. Em 
função disso, pode-se afirmar que essas estratégias são apenas rule based, e não derivadas como uma solução de um problema de otimização (Dawid, 2006).

Vale lembrar que, na abordagem neoclássica, os gastos em $\mathrm{P} \& \mathrm{D}$ são tratados a partir de uma ótica que visa encontrar uma estratégia de busca ótima, que reduza os custos, melhore a qualidade e diferencie o produto. Tal contexto se dá num ambiente em que os agentes possuem conhecimento perfeito de todos os eventos possíveis e são capazes de avaliar a incerteza probabilisticamente, bem como prever os resultados futuros e incertos. Portanto, os agentes não cometem erros sistemáticos na realização das suas escolhas.

Para a abordagem baseada no agente, por outro lado, as firmas não têm acesso livre a um número irrestrito de atividades produtivas, nem todos os processos estão sob o seu controle. Além disso, em um ambiente de incerteza e limitação das capacidades cognitivas e computacionais dos agentes, e diante dos altos custos econômicos de coleta e processamento de informações, haverá ausência de conhecimento pleno sobre as possibilidades de decisão, bem como as consequências das escolhas serão desconhecidas, uma vez que também dependerão das ações e decisões tomadas pelos demais agentes que compõem o sistema. Assim, qualquer tentativa de antecipação de certos eventos é tida como imperfeita, uma vez que os agentes decidem de forma autônoma e suas decisões são interdependentes.

A abordagem baseada no agente estuda em detalhe o processo de busca por inovações e a interação desses processos de busca com a dinâmica da indústria e a evolução das preferências do consumidor. Dawid (2006) destaca o desenvolvimento de alguns estudos nessa área.

Nesse sentido, destaca-se o modelo desenvolvido por Cooper (2000), no qual o autor considera que as firmas executam P\&D com o objetivo de solucionar problemas que são, em sua maioria, mal ilustrados e difíceis de resolver. De acordo com esse modelo, o aprendizado social acelera o processo de descoberta pelos melhores desenhos, e, diante de um ambiente de imitação parcial, as firmas 
combinam o desenho de diversas firmas na média, o que conduz a um aprendizado mais rápido se comparado a situações em que a firma simplesmente adota um desenho de outra firma, porque, diante de imitação parcial, a firma acaba por evitar a adoção de desenhos subótimos. Esses novos desenhos são comparados aos desenhos existentes, e a sua avaliação de sucesso ou fracasso apenas será feita quando esse desenho for colocado no mercado.

A heterogeneidade de comportamento e a existência de conhecimento imperfeito ${ }^{4}$ dos agentes é outra propriedade bastante importante que deve ser levada em consideração quando se pretende estudar os processos e efeitos da atividade inovativa.

Ambientes que exibem inovação são marcados por diversidade comportamental e instabilidade estrutural, e, portanto, não são compatíveis com o simples cálculo de otimização dos modelos ortodoxos tradicionais, os quais desconsideram a existência de incerteza e heterogeneidade ${ }^{5}$ entre os agentes, e, também, as diferenças de julgamento e percepção entre esses, uma vez que os agentes envolvidos são dotados de conhecimento perfeito de todas as propriedades. Assim sendo, pode-se afirmar que o modelo de agente representativo bayesiano, ao admitir racionalidade perfeita e conhecimento $e x$ ante de todos os estados possíveis, não é capaz de lidar com a discussão de incerteza e heterogeneidade presentes em ambientes que exibem inovação.

Ao propor algo oposto a essa perspectiva tradicional, deve-se partir da premissa de que as firmas procuram diferenciar suas técnicas de produção ou seus produtos dos seus competidores no mercado, gerando com isso heterogeneidade em todo o sistema. Partindo dessa condição, tem-se que o entendimento das estratégias e tecnologias adotadas pelas firmas são pontos fulcrais para a

4. Os autores evolucionários admitem um padrão de racionalidade que segue a abordagem de Simon.

5. A heterogeneidade de comportamento na análise neoclássica se resume simplesmente à heterogeneidade nas características dos agentes ou na dotação inicial. 
compreensão dos processos que governam a mudança tecnológica. A abordagem baseada no agente, ao lidar com complexidade e incerteza substantiva, torna-se, então, a forma mais adequada para lidar com a heterogeneidade de estratégias de inovação.

A existência de heterogeneidades permite a geração de novo conhecimento, o que se reflete em efeitos bastante positivos na indústria, pois as firmas procurarão se distinguir dos seus competidores por meio da implantação de novas atividades inovativas a fim de auferir resultados melhores (Dawid, 2006). Desse modo, a heterogeneidade das estratégias não pode apenas ser atribuída a diferenças de dotação, como sugere a abordagem tradicional. Além disso, elas não são induzidas apenas pelos efeitos que geram sobre os incentivos individuais das firmas, mas também porque geram efeitos importantes e significativos na evolução da indústria como um todo.

Dentre os modelos desenvolvidos a partir dessa perspectiva estão o de Dawid et al. (2001), que estudaram as diferentes circunstâncias em que as firmas se dedicam à imitação de modelos já existentes, em circunstâncias sob as quais elas desenvolvem os seus próprios projetos de inovação. $\mathrm{O}$ modelo desenvolvido pelos autores conclui que é mais vantajoso para a firma se desviar da estratégia da indústria média, e que as firmas têm incentivos para se desviar, gerando estratégia de heterogeneidade (Dawid, 2006, p.1255).

Outro modelo que considera a diversidade de estratégia na indústria é o de Llerena \& Oltra (2002), segundo o qual a probabilidade de inovação das firmas depende do estoque de conhecimento acumulado e não apenas do nível de investimento corrente. Além disso, o modelo pressupõe a existência de dois tipos de firmas: aquelas que constroem o seu estoque de conhecimento a partir do seu próprio $\mathrm{P} \& \mathrm{D}$ e, portanto, geram inovações internamente, e aquelas que, por outro lado, investem na construção de capacidade absortiva a fim de explorar o conhecimento gerado externamente. Enquanto as primeiras são caracterizadas como firmas inovadoras, as últimas são vistas como firmas imitadoras. 
O modelo mostra que, em indústrias homogêneas em que a inovação e a imitação coexistem, um padrão de evolução tecnológica superior ou de maior produtividade média será observado. Em indústrias heterogêneas, por outro lado, coexistem um número pequeno de grandes empresas inovadoras e muitas pequenas firmas imitadoras (Dawid, 2006, p.1256).

Outro modelo importante desenvolvido nessa perspectiva agent-based de mudança tecnológica é o de Chiaromonte \& Dosi (1993), no qual os autores compararam resultados de simulação em cenários em que as competências tecnológicas e as regras de decisão são heterogêneas, e em cenários em que esses parâmetros são homogêneos. As conclusões e resultados do modelo indicam que cenários em que a tecnologia e as regras de decisão são homogêneas conduzem a um progresso técnico e a uma renda agregada menor do que quando comparada a cenários em que esses parâmetros são heterogêneos (apud Dawid, 2006). Ballot \& Taymaz (1997, 1999) também adotam uma perspectiva evolucionária, e de maneira similar verificam que, na ausência de heterogeneidade das estratégias, o produto total e o nível de tecnologia alcançado são reduzidos. Além disso, mostram que baixos níveis de produtividade são gerados em situações em que as estratégias são dadas ex ante, e nas quais as firmas são incapazes de adaptar suas estratégias.

Feitas essas considerações acerca da capacidade dos modelos ACE de incorporar importantes aspectos do processo de inovação tecnológica em sua análise, a seção que segue tem por objetivo analisar a importância dessa abordagem no que diz respeito ao seu maior poder explicativo, o que está diretamente relacionado à sua maior capacidade de fornecer explicações aos fatos empiricamente estilizados. ${ }^{6}$

6. Os fatos estilizados dizem respeito aos fatos recorrentes. Correspondem às características agregadas dos fenômenos. 


\section{A emergência dos fatos estilizados}

Os fatos estilizados, entendidos como características agregadas, emergem como propriedades agregadas, ou seja, emergem como um resultado das hipóteses sobre as interações econômicas no nível micro, isto é, a partir das hipóteses feitas a respeito da forma como os agentes interagem. Segundo Dawid (2006), os modelos ACE desenvolvidos nessa perspectiva têm sido bem-sucedidos em reproduzir fatos estilizados tanto de uma perspectiva da indústria como da perspectiva do crescimento econômico. ${ }^{7}$

Mais especificamente, no que se refere à perspectiva da indústria, as empresas que são heterogêneas podem apresentar diversas características que são particulares a elas. Entre outros fatores, elas podem diferir quanto à tecnologia empregada, quanto à produtividade, quanto ao lucro, etc. Disso segue que os padrões de evolução podem variar em diversos aspectos de indústria para indústria, mas, apesar disso, é possível identificar certas similaridades ou regularidades entre esses padrões, ou seja, é possível identificar características que são comuns a um grande número de firmas.

Esses padrões podem ser reproduzidos utilizando-se modelos ACE, modelos esses que são capazes de incorporar muitas características de interação e comportamento no nível micro. Neles, os padrões macro regulares emergem da interação micro não coordenada e descentralizada.

$\mathrm{Na}$ perspectiva de evolução da indústria, dentre os modelos ACE que têm sido bem-sucedidos em reproduzir os fatos estilizados são apresentados tanto modelos que seguem a tradição evolucionária, como uma nova geração de modelos econômicos evolucionários que ficou conhecida como modelos history friendly (Dawid, 2006).

7. Estudos nessa linha de pesquisa foram publicados por autores como Silverberg \& Verspagen (1994, 1995, 1996), Chiaromonte \& Dosi (1993), Chiaromonte et al. (1993), Dosi et al. (1994) e Fagiolo \& Dosi (2003). 
Dentre os modelos do primeiro grupo estão os desenvolvidos por Dosi et al. (1995) e Winter et al. (2000, 2003). Neles, os autores procuraram reproduzir os fatos estilizados no que diz respeito à distribuição do tamanho da firma em muitas indústrias, à coexistência de firmas com diferentes eficiências na produção, às vantagens de longo prazo dos entrantes antigos, e à importância na indústria do regime tecnológico para as características de evolução da indústria (apud Dawid, 2006, p.1260).

Apesar da sua grande importância, para Dawid (2006, p.1260), esses modelos são apenas em algum sentido agent-based, uma vez que seu foco está na análise da evolução das distribuições no nível da indústria e nas interações entre os agentes, sendo que as regras de interação entre os agentes são apenas consideradas em forma reduzida.

O uso da matemática e a crescente formalização incorporada aos modelos evolucionários com o objetivo de discutir as inovações foram bastante importantes para colocar as discussões dessa linha de pesquisa no mainstream do debate acerca da inovação. No entanto, esse formalismo também desempenha um papel bastante restritivo, na medida em que passa a ser mais valorizado do que "a riqueza empírica, o poder explicativo, a robustez conceitual, o poder da política ou mesmo a capacidade preditiva" (Hodgson, 1999, p.146).

Segundo Dawid (2006), esses modelos são formulados em uma estrutura bastante abstrata, na qual o modelador tem liberdade para adaptar as hipóteses e gerar certos fatos estilizados, consequentemente,

esses modelos (de maneira similar à teoria econômica formal tradicional) destacam quais mecanismos são explicações potenciais para o fenômeno observado [...] Argumenta que [...] a fim de ser mais confiável na captura das causalidades vigentes em dadas indústrias concretas, deveria ser necessário ligar os blocos de construção do modelo com as observações empíricas nessa dada indústria. (Dawid, 2006, p.1260) 
Nesse sentido, outra geração de modelos econômicos evolucionários propostos por Malerba et al. ${ }^{8}(1999,2001)$, que ficou conhecida como history friendly, tem sido estudada. Modelos history friendly são modelos formais que buscam capturar de forma estilizada a essência das teorias qualitativas e apreciativas sobre os mecanismos e fatores que afetam a evolução da indústria. $\mathrm{O}$ modelo busca, a partir de uma estrutura formalizada, explicar os padrões de evolução de uma indústria ou da tecnologia que são colocados pelos pesquisadores empíricos dessa indústria.

Tais modelos

devem ser desenvolvidos baseados em considerações detalhadas acerca das características da indústria. [...] Além disso, devem ser capazes de reproduzir os principais fatos no desenvolvimento histórico da indústria. A ideia é iniciar com descrições verbais da estrutura presente de uma indústria e então traduzir os argumentos verbais em um modelo formal. (Dawid, 2006, p.1260)

Malerba et al. (2001) argumentam que esses modelos tendem a incorporar detalhes mais específicos da indústria do que os modelos da economia tradicional. E como tais explicações verbais para os padrões particulares envolvem uma dinâmica não linear, dada a sua complexidade, o modelo resultante tem a estrutura de um modelo de simulação dinâmico agent-based.

Apesar dos significativos avanços verificados, Dosi \& Winter (2003) destacam a dificuldade ou até mesmo a impossibilidade de incorporar "novidade genuína" nos modelos evolucionários, pois, caso pudesse ser incorporada no modelo, seria apresentada como rotina e não como criatividade. Nesse sentido, os modelos de inovação baseados em complexidade são apenas capazes de destacar

8. Malerba et al. $(1999,2001)$ desenvolveram um modelo desse tipo para a indústria de computadores e as especificações do modelo foram escolhidas com base nas observações empíricas da indústria em questão.

9. A novidade só é considerada genuína quando ela não é causada por um evento anterior (uncaused cause). 
que a existência de novidades gera variedade e a partir desses modelos pode-se mostrar que essa variedade endogenamente gerada pela inovação gera padrões de dinâmica industrial. Assim, conclui-se que, embora a criatividade genuína não possa ser incorporada no modelo, a teoria da complexidade pode mostrar que, presumindo que a inovação existe e é endógena, a criação de variedade leva a padrões e mudanças de padrão na dinâmica industrial.

De maneira geral, verifica-se que a abordagem de simulação baseada no agente apresenta-se como uma importante ferramenta de análise quando utilizada em discussões relacionadas à inovação e mudança tecnológica. Sua superioridade pode ser explicada pela sua maior capacidade de incorporar as quatro propriedades do processo de inovação aos seus modelos, o que lhe confere um maior poder explicativo frente à abordagem neoclássica tradicional, pois, ao desconsiderar a possibilidade de conhecimento ex ante sobre os resultados futuros, é capaz de lidar com a incerteza substantiva forte e com heterogeneidades das estratégias.

A importância desses modelos também é associada a sua grande capacidade em fornecer explicações aos padrões agregados observados, os quais emergem como propriedade das hipóteses sobre as interações no nível micro. Assim, por exemplo, tal modeloé capaz de relacionar as estruturas de mercado com as diferentes variáveis indicativas de desempenho da indústria e verificar, desse modo, como um fato estilizado, no caso uma dada estrutura de mercado, emerge a partir das interações econômicas no nível micro. De outro modo, como as diferentes estruturas de mercado observadas podem ser relacionadas, dentre outros fatores, às diferentes estratégias de inovação empreendidas pelas firmas, ao próprio estágio de desenvolvimento da indústria, à produtividade da firma, ao número de firmas do setor, ao crescimento econômico, etc.?

$\mathrm{E}$ a capacidade desses modelos em reproduzir comportamentos agregados, sob dadas condições econômicas, são importantes em situações em que tais modelos são utilizados para realizar previsões ou avaliações acerca dos efeitos da implementação de políticas. 
Assim, essa seção teve por objetivo justificar a importância e maior eficácia de se pensar as inovações tecnológicas em uma perspectiva agent based. Foi destacado que grande parte dos modelos desenvolvidos a partir dessa perspectiva baseia-se no modelo de inovação tecnológica proposto por Nelson \& Winter([1982]/2005). Diante da sua grande importância e influência, torna-se importante realizar um estudo mais detalhado desse modelo.

\section{O modelo de concorrência schumpeteriana}

O progresso técnico na abordagem evolucionária de Nelson \& Winter ([1982]/2005) é visto como um instrumento de competição, apresentando-se como uma das principais fontes de crescimento e mudança estrutural na economia.

Os autores desenvolveram um modelo de concorrência schumpeteriana e evolução industrial que tem grande importância teórica, dado que apresenta uma das principais contribuições no sentido de apresentar uma modelagem da concorrência com mudança técnica endógena sob pressupostos de desequilíbrio e racionalidade limitada. Apesar de apresentar algumas limitações, tal modelo forneceu conclusões importantes acerca da relação entre estrutura de mercado e processo de mudança tecnológica, bem como serviu de base para diversos modelos de dinâmica industrial ${ }^{10}$ desenvolvidos posteriormente. ${ }^{11}$

10. Segundo Windrum (2004), três elementos-chave do modelo de Nelson \& Winter ([1982]/2005) são seguidos pelos demais modelos neo-schumpeterianos: i) heterogeneidade de estratégias entre as firmas, ii) mecanismos de seleção de mercado, e iii) os mecanismos de geração de novidade que podem se dar por busca local ou por imitação.

11. Dentre esses, vale citar uma própria extensão do modelo, desenvolvida por Winter (1984), que buscou explorar novas fontes de mudança técnica e que também introduziu algumas alterações. Além desse, Silverberg et al.(1988), Chiarommonte \& Dosi (1993), Caccomo (1996) e Possas et al. (2001) partem da estrutura sugerida inicialmente por Nelson \& Winter ([1982]/2005) e 
A questão da estrutura de mercado tem grande importância para o desenvolvimento dessa teoria schumpeteriana, que considera o tamanho da firma e o grau de concorrência importantes para a tomada de decisões econômicas de um inovador, o que se explica a partir do argumento de que

As grandes firmas têm níveis de produção, capacidade produtiva, arranjos de comercialização e finanças que lhes permitem explorar rapidamente uma nova tecnologia numa escala relativamente grande. [...] Além do que [...] a ausência de concorrentes e a habilidade de bloquear a imitação dos concorrentes são fatores que por si só influenciam a apropriabilidade. ${ }^{12}$ Dito de outro modo, a estrutura de mercado influencia a velocidade com que as quase-rendas provisórias são erodidas pelos imitadores. Essa relação é presumivelmente o que Schumpeter tinha em mente quando declarou que a concorrência perfeita era incompatível com a inovação. (Nelson \& Winter, [1982]/2005, p.405-6).

Os ambientes que exibem inovação são ambientes marcados por incerteza tanto para os agentes envolvidos como para aqueles que são afetados pelas inovações dos primeiros. Todavia, alguns aspectos, especificamente o tamanho da empresa, entre outros, podem contribuir para aplainar tais "problemas", ou seja, podem contribuir para reduzir o grau de incerteza dos inovadores. Assim, quanto maior o poder de mercado, ou quanto maior o grau de monopólio de uma firma, maior é a possibilidade de esta obter uma elevada taxa de retorno, dado que menores são as incertezas ocasionadas pela concorrência.

buscam igualmente introduzir mudanças, a fim de remover as simplificações existentes (Almeida, 2004).

12. Vale notar, no entanto, que, apesar da importância dada a esse fator, o modelo desenvolvido por Nelson \& Winter ([1982]/2005) não foi capaz de modelar a apropriabilidade. 
Além do mais, o poder de mercado somado à habilidade das firmas de bloquear a imitação influencia a apropriabilidade, o que implica um importante fator de influência sobre as políticas de inovação.

Como já foi visto anteriormente, para Nelson \& Winter ([1982]/2005), a concorrência de mercado em determinado setor constitui um ambiente de seleção. Destacam que tal discussão já estava presente nos escritos de Schumpeter. Nesse sistema, as firmas são motivadas a introduzir novos métodos de produção ou novos produtos, a fim de se manter e elevar sua participação no mercado. O resultado disso será expansão de lucro das inovadoras, que vislumbrarão aumentos nos níveis de produtividade e redução dos custos unitários de produção, ou ainda maiores parcelas de mercado. Por outro lado, haverá contração das não inovadoras, que serão estimuladas a imitar as estratégias das primeiras, a fim de melhorar a sua rentabilidade e competitividade no mercado.

Já em ambientes que apresentam pouca concorrência, as firmas alcançam altos retornos em suas atividades, o que incentiva pouco a realização de investimentos em $\mathrm{P} \& \mathrm{D}$ inovativo. Assim, caso a participação de mercado dessa firma já seja bastante grande e haja poucas possibilidades de expansão, a firma terá poucos incentivos para continuar expandindo seus investimentos em $\mathrm{P} \& \mathrm{D}$ inovativo, dada a fraca pressão de seus concorrentes e a ausência do risco de ser expulsa desse mercado.

Diante disso, maior deverá ser a razão preço-custo necessária para induzir a expansão dos investimentos. Por outro lado, em ambientes marcados por forte concorrência e, portanto, grande facilidade de imitação ou baixas condições de apropriabilidade, as firmas se apropriam facilmente dos investimentos realizados pelas inovadoras e, nessa busca por um "rápido segundo lugar", elas expulsariam do negócio as verdadeiras inovadoras, podendo dominar o ramo (Nelson \& Winter, [1982]/2005, p.407).

$\mathrm{O}$ contexto descrito permite estabelecer a existência de uma relação de causalidade entre a estrutura de mercado e a inovação, de 
tal forma que a estrutura de mercado gera reflexo sobre a inovação, mas esta também é capaz de alterar a estrutura de mercado. O modelo de crescimento desenvolvido por Nelson \& Winter ([1982]/2005) procura reproduzir os aspectos essenciais da concorrência schumpeteriana, a partir da identificação das relações ou conexões existentes entre as estruturas de mercado, os dispêndios em $\mathrm{P} \& \mathrm{D}$, o avanço técnico e outras variáveis indicativas de desempenho da indústria. Dada a complexidade de tal conexão, os autores sugerem que

o desafio da modelagem é elaborar uma estrutura formal simples que permita a exploração de algumas das mais interessantes dessas conexões, e que seja suficientemente transparente para que os resultados do modelo possam ser entendidos e reconsiderados no contexto da realidade mais complexa. (p.408)

Dentre as hipóteses que caracterizam esse modelo estão: 1) as firmas produzem um produto homogêneo; 2) a firma opera uma única técnica, que é a melhor disponível no período; 3 ) as técnicas são caracterizadas por retornos constantes à escala e coeficientes fixos de insumos; 4) a oferta dos fatores é perfeitamente elástica e seus preços são constantes ao longo do período em questão; 5) a firma pode elevar sua produtividade a partir de gastos em $\mathrm{P} \& \mathrm{D}$ inovativo e em P\&D imitativo, e a magnitude desses gastos reflete o tamanho da firma, já que são proporcionais ao capital (Nelson \& Winter, [1982]/2005, p.408-9).

Dado que as técnicas requerem os mesmos insumos complementares por unidade de capital, e que os preços dos insumos do ramo são constantes, os custos por unidade de capital das firmas também serão constantes.

Entretanto, o custo por unidade do produto se apresenta como uma variável do modelo, já que são as diferentes técnicas utilizadas pela firma, ou os diferentes níveis de produtividade, que determinam os custos unitários. Desse modo, à medida que novas técnicas mais produtivas são colocadas em uso, seja por meio de 
políticas de $\mathrm{P} \& \mathrm{D}$ inovativo, seja por meio de políticas de $\mathrm{P} \& \mathrm{D}$ imitativo, o custo do produto tende a cair.

Nesse modelo, o produto da firma $i$ no tempo $t, Q_{i t}$, é igual ao seu estoque de capital, $K_{i t}$, multiplicado pela técnica de produção, $A_{i t}$. E o produto do ramo, por sua vez, é a soma dos produtos das firmas individuais. Ou seja,

(1) $Q_{i t}=A_{i t} K_{i t}$

(2) $Q_{t}=\Sigma Q_{i t}=\Sigma A_{i t} K_{i t}$

O preço é determinado pelas condições de demanda com que a indústria se depara.

(3) $P_{t}=D\left(Q_{t}\right)$

A partir do custo unitário de produção e do preço do produto é possível determinar para cada firma a razão entre o preço e o custo unitário de produção, ou a razão preço-custo que também é conhecido como mark-up da empresa.

O lucro sobre o capital é determinado pela receita total por unidade do capital subtraída do custo total de produção por unidade de capital e dos custos de P\&D inovadores e imitadores por unidade de capital.

(4) $\Pi_{i t}=\left(P_{t} A_{i t}-c-r_{i m}-r_{i n}\right)$

É através do processo de busca tecnológica, que pode ocorrer tanto por meio de políticas de imitação como de inovação, que as firmas introduzem novas técnicas, a fim de elevar a sua produtividade. Assume-se que a indústria seja um mix de inovadores e imitadores.

E os dispêndios em $\mathrm{P} \& \mathrm{D}$ inovativo ou imitativo são definidos por unidade de capital. Diante disso, os níveis de dispêndios em $\mathrm{P} \& \mathrm{D}$ inovativo e imitativo, que geram diversidade entre as firmas e 
modificam as suas produtividades, crescerão quando as empresas crescerem, e serão reduzidos quando as empresas estiverem em declínio. Com isso, é possível afirmar que a magnitude desses gastos reflete o tamanho da firma, pois as firmas grandes gastarão mais em $\mathrm{P} \& \mathrm{D}$ do que as firmas pequenas. Contudo, os resultados desses dispêndios são incertos, e, portanto, desconhecidos previamente. Como resultado, o sucesso de imitação ou inovação é expresso a partir das seguintes probabilidades:

$$
\operatorname{Pr}\left(d_{i m t}=1\right)=a_{m} r_{i m} K_{i t}
$$

(6) $\operatorname{Pr}\left(d_{\text {int }}=1\right)=a_{n} r_{i n} K_{i t}$

Disso segue-se que a probabilidade de que a firma inove ou imite é proporcional ao dispêndio da firma nessas atividades. $\mathrm{O}$ sucesso da imitação permite que a firma copie a melhor prática do setor e que, portanto, incorpore a maior produtividade.

No caso de P\&D inovativo, por outro lado, a produtividade alcançada pela firma não é conhecida previamente, mas é o resultado de um processo estocástico de dois estágios, em que se verifica que

sucesso no primeiro estágio garante acesso no segundo estágio no qual a firma acessará uma tecnologia cuja produtividade não é conhecida previamente. Assim, a produtividade a ser obtida é uma variável aleatória que possui distribuição log normal, cuja média cresce a uma taxa exógena [...] que dá o ritmo de expansão da produtividade latente. ${ }^{13}$ (Almeida, 2004b, p.294)

No caso de gastos com P\&D inovativo e imitativo, o nível de produtividade será dado pela produtividade da técnica até então

13. De acordo com Nelson \& Winter ([1982]/2005, p.411) "sob essa especificação, o que a firma obtém hoje como resultado de uma escolha de inovação independe do que ela pode ter encontrado no ano passado ou no ano retrasado. E o universo que serve de base à escolha é mais rico em técnicas produtivas do que o das escolhas anteriores". 
utilizada pela firma, pela produtividade da técnica copiada, ou seja, pela produtividade da melhor prática, e pela produtividade obtida através do sucesso inovativo, ou seja:

$$
\text { (7) } A_{i(t+1)}=\operatorname{Max}\left(A_{i t}, \hat{A}_{i}, \tilde{A}_{i t}\right)
$$

As firmas são caracterizadas pelos lucros que investem em imitação e inovação e também pela sua função investimento, que, por sua vez, determina a sua expansão ou contração no mercado. E dentre os fatores determinantes das decisões de investimento da firma estão: i) o mark-up da firma (isto é, a razão entre o preço e o custo unitário de produção); ii) a sua participação no mercado; iii) a sua lucratividade, que, indiretamente, pode afetar a capacidade de investimento da firma, através das limitações de financiamento que pode impor; e iv) a taxa de depreciação física do capital.

Uma das principais conclusões desse modelo é que, à medida que melhores tecnologias são encontradas ao longo do tempo, os níveis de produtividade tendem a se elevar; em contrapartida, os custos unitários de produção tendem a cair. E, como resultado, o preço tende a cair e a produção do ramo tende a aumentar. As firmas lucrativas se expandem e as não lucrativas se contraem.

A partir das simulações computacionais, Nelson \& Winter ([1982]/2005, p.423-35) procuraram relacionar a influência da concentração inicial do setor sobre o seu desempenho, e também procuraram relacionar os efeitos da concentração sobre a maneira pela qual a estrutura do setor evolui ao longo do tempo. Dentre as variáveis de desempenho do setor, analisadas pelos autores, estão: a produtividade do ramo, a produtividade média, os custos de produção do setor, os preços, e os efeitos da concentração.

Em um primeiro passo, esses resultados são comparados para uma indústria baseada na ciência. Os autores analisam cinco conjuntos diversos de condições iniciais, com 2, 4, 8, 16 e 32 firmas. Consideram ainda que as firmas se deparam com dois regimes diferentes de financiamento. Enquanto, em um regime, a firma pode tomar emprestado 2,5 vezes seus próprios lucros líquidos para fi- 
nanciar os investimentos, no outro regime, os empréstimos da firma são limitados aos seus lucros.

Os autores supõem ainda que metade das firmas gasta em $\mathrm{P} \& \mathrm{D}$ inovadoras e imitadoras e a outra metade apenas em P\&D imitadoras. Todas as firmas são inicialmente do mesmo tamanho e têm o mesmo nível de produtividade e os mesmos custos de produção iniciais, contudo, as que gastam em P\&D inovadoras e imitadoras têm custos totais por unidade de produto mais alto.

Os resultados alcançados a partir das simulações foram os seguintes:

(1) A produtividade das firmas inovadoras (produtividade da melhor prática) é superior à das imitadoras, entretanto, essa produtividade mostrou-se pouco relacionada com a estrutura de concentração inicial, uma vez que, para os cinco conjuntos analisados, a produtividade apresentou pouca variação de uma estrutura para outra. Contudo, mesmo assim foi possível verificar que a produtividade das firmas inovadoras é um pouco menor no caso em que há uma estrutura mais competitiva (32 firmas) do que no caso em que há menos concorrência ( 8 firmas).

(2) A produtividade média da indústria também está relacionada ao grau de concentração, uma vez que os resultados mostraram que, diante de uma estrutura mais concentrada, a produtividade média cresce mais rapidamente e os custos médios de produção caem mais rapidamente do que no caso de estruturas menos concentradas. Além disso, quanto maior for essa firma inovadora ou imitadora maior será o impacto sobre a produtividade média, dado que a primeira é capaz de aproveitar por mais tempo os resultados decorrentes da inovação enquanto a segunda é capaz de se aproveitar da imitação.

(3) Quanto aos custos de produção, estes também se mostraram relacionados ao grau de concentração e as simulações indicaram que, em estruturas mais competitivas, os custos de produção são maiores, já que a produtividade média é menor. E disso segue que o mark-up médio da indústria (razão preço-custo) também é menor em estruturas mais competitivas. Assim, em estruturas 
menos competitivas, as firmas com grande poder de mercado têm o poder de arbitrar preços, independente do preço médio praticado na indústria, gerando, portanto, preços e margens de lucro maiores.

(4) $\mathrm{O}$ índice Hirschman-Herfindahl (uma medida de concentração da produção na indústria) indicou que estruturas iniciais concentradas tendem a permanecer concentradas e que estruturas iniciais mais competitivas tendem a se concentrar. E esse aumento da concentração implica a redução das políticas de investimento em $\mathrm{P} \& \mathrm{D}$ inovadores.

Após realizar uma pequena apresentação desse modelo, procurando destacar as hipóteses da qual ele parte e os principais resultados alcançados pelas simulações realizadas, a próxima seção tem por objetivo identificar as características desse modelo que permitem aproximá-lo da abordagem dos sistemas complexos, ou da perspectiva agent-based.

\section{O modelo evolucionário de Nelson e Winter e o método ABM}

Nelson \& Winter ([1982]/2005) relacionam o processo de modelagem com os avanços da pesquisa empírica e a importância de seu trabalho é notória, quando se verifica que diversos estudos posteriores foram desenvolvidos e receberam influência desse modelo inicial. $^{14}$

Para Dawid (2006), dentre os argumentos que justificam a utilização de métodos de simulação em ambientes que exibem mudança tecnológica estão: i) a existência de feedbacks entre o indivíduo e a população; e ii) a maneira com que o processo de tomada de decisão é enxergado dentro da firma.

No que diz respeito ao primeiro argumento, verifica-se que, assim como a população é determinada pela agregação das decisões individuais, as decisões dos indivíduos também são determinadas

14. Alguns trabalhos, entretanto, também vêm sendo conduzidos fora do escopo da análise evolucionária. 
pelas características da população. Mais especificamente, interessa relacionar essa perspectiva à geração, seleção e difusão de inovações, num contexto em que as estruturas observadas na população são um reflexo das decisões tomadas internamente, mas também que as decisões dos indivíduos estão diretamente relacionadas ao todo.

Segundo Dawid (2006), tal perspectiva requer uma análise do indivíduo e da população, assim como uma análise do feedback entre os dois. E essa interação envolve variedade, o que implica a existência de heterogeneidade de comportamento entre os agentes econômicos, de modo que tal análise requer métodos de simulação.

$\mathrm{Na}$ abordagem evolucionária, mais especificamente em ambientes que exibem inovação, os conjuntos de escolhas não são conhecidos e dados, e as firmas não respondem da mesma forma aos sinais de mercado, apresentando diversidade de comportamento e respostas diferenciadas às situações enfrentadas, ${ }^{15}$ o que impossibilita a tomada de decisões maximizadoras por parte dos agentes, que, por outro lado, agem sob racionalidade procedimental e são guiados por práticas rotineiras de conduta.

Tal mudança de foco torna os modelos baseados no agente uma escolha natural, uma vez que eles facilmente permitem a incorporação de processos de decisão confiando em conjuntos ou hierarquias de regras, enquanto tais tentativas são desajeitadas em formulações analíticas puras e em geral não admitem caracterizações matemáticas gerais. (Dawid, 2006, p.1245)

Nesse ambiente, de maneira diferente, as firmas, para tomarem suas decisões, procuram desenvolver rotinas a fim de lidar com as situações enfrentadas ao longo do tempo. O processo de tomada de decisões é então caracterizado pelo seu grupo de rotinas, as quais desempenham um importante papel como memória organizacional.

15. Tal diversidade de respostas é verificada até mesmo em situações em que as firmas estão expostas aos mesmos sinais de mercado. 
De maneira geral, esses modelos caracterizam-se por simplificar as decisões e reduzir o número de variáveis envolvidas e o custo no processamento, cálculo e gerenciamento das decisões. Algumas dessas rotinas desenvolvidas se sobressaem ao longo do tempo por representar respostas superiores para os problemas enfrentados, enquanto outras acabam sendo descartadas. Logo, são as rotinas mais bem desenvolvidas, denominadas estratégias de busca, que determinarão o nível e a direção da busca, as quais, por sua vez, influenciam a forma e a velocidade da mudança tecnológica.

No modelo de concorrência schumpeteriana desenvolvido na seção anterior, as estratégias assumidas não partem de condições de equilíbrio ou de cálculos de maximização, mas são resultado de diversidade e incerteza entre as firmas.

O modelo considera dois tipos de comportamento da empresa: as políticas voltadas para a inovação e as políticas voltadas para a imitação. Considera ainda que as empresas, ao se engajarem em uma estratégia de $\mathrm{P} \& \mathrm{D}$, não têm condições de saber se serão ou não bem-sucedidas, e tampouco poderão conhecer o nível apropriado de $\mathrm{P} \& \mathrm{D}$ inovativo ou imitativo, dado que as respostas a essas questões também dependem das escolhas feitas pelas outras firmas.

Desse quadro, deve-se levar em conta o processo de aprendizagem e apenas o curso dos acontecimentos poderá revelar se a estratégia foi ou não bem-sucedida. Ou seja,

apenas o curso dos eventos ao longo do tempo determinará e revelará quais são as melhores estratégias. E mesmo o veredicto da percepção tardia do que deveria ter sido feito pode não ser claro, pois diferenças de sorte podem fazer que as mesmas políticas que são brilhantemente bem-sucedidas para algumas firmas sejam fracassos funestos para outras. (Nelson \& Winter, [1982]/2005, p.415).

Ao tratar dessas decisões, que estão envoltas pelo ambiente de incerteza, Nelson \& Winter (1977) também chamam a atenção para a necessidade de estudar as questões relacionadas às instituições, uma vez que estas desempenham um importante papel na ge- 
ração e na exploração da inovação, e fornecem um entendimento mais esclarecedor do comportamento do que a hipótese de escolha plenamente racional.

A inclusão da discussão acerca das instituições é fundamental, uma vez que elas se encontram diretamente relacionadas ao comportamento das firmas, que estão numa constante busca pelo aumento de sua base de conhecimento. A importância das instituições está ainda diretamente relacionada ao arcabouço legal que garante as condições de apropriabilidade, isto é, a facilidade ou dificuldade de imitação em determinado mercado.

Com relação ao primeiro argumento, vale observar que a inovação tecnológica, para a abordagem evolucionária, não se apresenta como um processo puramente aleatório, resultante de um ato único do inovador, sobretudo porque se desenvolve por meio de procedimentos estabelecidos presentes nas rotinas, na busca e na seleção (interna e externa). Também não pode ser vista como um processo cujo resultado desaponta, uma vez que recebe crescente apoio dos avanços científicos em diversas áreas. A inovação, por outro lado, é também enxergada como um processo que sofre transformações ao longo do tempo, e geralmente é definida em relação à tecnologia já em uso; em relação às condições econômicas; e também em relação aos avanços tecnológicos já conquistados em outras firmas, organizações ou países (Dosi, 1988d).

A atividade inovativa, nesse sentido, envolve de modo predominante uma organização formal obtida a partir da infraestrutura tecnológica - dos laboratórios em P\&D das grandes empresas, governos e universidades, e também a partir das relações entre ciência e tecnologia. Além disso, a existência dessa organização formal permite descrever o ambiente no qual a firma opera e sua existência torna o processo inovativo uma constante nas atividades da firma, o que faz com que as inovações sejam enxergadas como uma atividade profissional e não como uma atividade meramente ocasional ou circunstancial.

O processo inovativo passa então a ser visto como um processo institucionalizado, no qual as atividades inovativas são cada vez 
mais sistemáticas e integradas às atividades das firmas, de tal modo que tais atividades passam a estar vinculadas a um esforço permanente por parte dessas firmas no que diz respeito ao desenvolvimento de novos processos de busca, novos mecanismos de seleção e novos procedimentos rotineiros voltados à criação de novos produtos e processos ${ }^{16}$ e também ao aperfeiçoamento de produtos e processos já existentes.

Segundo Dosi (1988b), tal forma de exploração da inovação, isto é, a partir da consideração dessas organizações integradas de pesquisas, tem se sobressaído em relação aos inovadores individuais, uma vez que se apresenta como sendo mais eficiente do que estes na exploração e na internalização dos aspectos cumulativos e tácitos do conhecimento tecnológico.

Além disso, diante da existência desses aspectos tácitos, idiossincráticos e particulares à firma, os laboratórios de $\mathrm{P} \& \mathrm{D}$ industrial presentes no interior da firma, os quais estão diretamente relacionados aos departamentos de produção e marketing, tornam-se mais vantajosos do que os laboratórios de $\mathrm{P} \& \mathrm{D}$ externos, uma vez que a pesquisa é moldada de acordo com essas particularidades. E tal forma de organização caracteriza-se por facilitar a comunicação e o fluxo de informação entre o laboratório de $\mathrm{P} \& \mathrm{D}$ e a firma e vice-versa.

De acordo com Dosi (1988b), esses indivíduos e grupos ligados por meio de rotinas aumentam a eficiência organizacional, uma vez que esses processos estão relacionados a aumentos nas habilidades das organizações empresariais em aprender e desenvolver procedimentos que elevem a eficiência na produção. Diante disso, as pesquisas conduzidas pelas organizações formais, uma vez mais, são mais eficientes na internalização dos aspectos cumulativos e tácitos do conhecimento tecnológico.

16. Para a criação desse ambiente econômico favorável, as empresas estão empenhadas em criar infraestrutura tecnológica, desenvolver formas de aprendizado, interagir com universidades e centros de pesquisas tecnológicas, dificultar imitação de resultados inovativos, etc. 
Entretanto, apesar da crescente rotinização das atividades inovativas, estas ainda possuem um componente de incerteza, o qual pode ser relacionado sobretudo à falta de conhecimento ex ante dos custos e resultados das diferentes alternativas, e também à falta de conhecimento de quais são as alternativas disponíveis.

O comportamento, que é caracterizado como rule-guided, ${ }^{17}$ é representado na forma de rotinas que podem não ser ótimas, e, diante disso, a busca por melhores rotinas estão sempre presentes. Em tais situações, as instituições ${ }^{18}$ podem atuar como fontes redutoras de incerteza, ao desempenhar um papel restritivo e, diante disso, controlar o comportamento e pensamento das pessoas, e ao dar estabilidade ao pensamento e ao comportamento dos agentes (Dequech, 2007).

Outro importante argumento para justificar a relação entre o presente tema e os aspectos institucionais reside na necessidade de compreender o papel do arcabouço legal que garante as condições de apropriabilidade das empresas, protegendo as inovações das imitações dos seus concorrentes, e garantindo que as empresas inovadoras se apropriem dos benefícios econômicos acumulados das suas pesquisas. Isso protege as empresas de um eventual processo de imitação por parte dos seus concorrentes, o que, por seu turno, amplia os incentivos que envolvem a exploração de novas oportunidades tecnológicas.

Cabe ressaltar que, numa condição em que as instituições são pouco ativas na proteção às patentes, ou seja, em condições em que o conhecimento é facilmente difundido e, portanto, de baixa

17. Os comportamentos são "[...] guiados e restringidos por valores socialmente assegurados e impostos, normas, convicções, costumes e práticas geralmente aceitas" (Dosi \& Nelson, 1994, p.159).

18. De acordo com Dequech (2007), as instituições podem ser de dois tipos: formais e informais. Dentre as instituições formais que contribuem para a redução da incerteza, o autor destaca: os contratos; as leis; os market makers; e as agências de Estado. E entre as instituições informais destaca as convenções e as normas sociais informais. 
apropriabilidade, ${ }^{19}$ as empresas teriam pouco incentivo para investir em inovação. Em geral, a estrutura institucional é bastante complexa e pode ser bastante diferente e variar entre os diversos setores. Ela depende de alguns fatores como: as tecnologias básicas, a natureza da demanda pelos bens e serviços, e as características das organizações.

Portanto, a discussão acerca da inovação, não pode ser resumida apenas a uma questão de tamanho ou poder de mercado das firmas, como sugere a abordagem ortodoxa ao imputar significativo peso a esses fatores (Nelson \& Winter, 1977). Isso porque as firmas diferem tanto em tamanho como em capacitação tecnológica, estratégias de produção e comercialização, graus de inovatividade e de sucesso competitivo, custos de produção e lucratividade. Nesse sentido, um entendimento da relação entre a inovação e o desempenho das firmas também implica uma análise do processo competitivo e dos mecanismos de aprendizado mediante os quais a indústria evolui (Dosi, 1988b).

De maneira geral, é por meio das buscas tecnológicas, seja por imitação ou inovação, que as firmas introduzem novas técnicas na tentativa de melhorar ou ao menos manter seu desempenho competitivo dentro da indústria. A introdução de novas técnicas a partir do processo de busca cria assimetrias competitivas, uma vez que as diferentes estratégias de inovação ou imitação geram diferentes impactos sobre o desempenho das firmas, que podem ser traduzidas em vantagens de custos ou em outras formas de vantagens de desempenho. E essas assimetrias tecnológicas e variedade tecnológica são enxergadas tanto como um resultado quanto como uma força motriz da mudança organizacional e tecnológica. E é essa diversidade que alimenta o processo de seleção da indústria (Almeida, 2004).

19. Disso segue-se que os direitos de apropriação das inovações tecnológicas podem, em alguns casos, ser garantidos institucionalmente, por meio, por exemplo, do direito de patentes. 
Nelson \& Winter ([1982]/2005) procuraram construir um modelo de simulação que fosse capaz de admitir e gerar uma diversidade de comportamentos no nível das firmas individuais e também que fosse capaz de explicar os padrões de variáveis agregadas, isto é, os fatos estilizados que emergem das interações no nível micro. Tal arcabouço teórico evolucionário, ao lidar com variedade e diversidade de estratégias, requer métodos de simulação para o seu desenvolvimento, pois os agentes se baseiam em regras que diferem tanto com relação ao seu estoque de capital e emprego de tecnologia, mas também com relação às estratégias de produção e inovação, de tal forma que, enquanto algumas firmas se empenham em liderar as inovações tecnológicas, outras estão empenhadas apenas em acompanhar o sucesso das primeiras por meio de imitação.

Isso implica que o comportamento do tomador de decisão deve ser determinado por um processo de seleção entre diferentes alternativas e não meramente por um cálculo de otimização bem definido. E, dada a tecnologia e as rotinas utilizadas pelas firmas, o seu desempenho será determinado tanto pelo que estiverem realizando como pelo que os seus competidores estão fazendo no mercado. E esse processo de seleção que se estabelece tende a gerar estruturas industriais bastante diferenciadas umas das outras, o que, ao gerar diversidade e variedade no sistema, afasta-o das posições de equilíbrio propostas pela abordagem neoclássica tradicional. 


\section{ConClusões}

É possível fazer uma recapitulação dos principais aspectos discutidos ao longo deste livro. Ele preocupou-se em mostrar as limitações da abordagem neoclássica tradicional em fornecer explicações consistentes acerca do desenvolvimento de inovações tecnológicas. A partir disso buscou outras abordagens e teorias que fossem capazes de tratar da questão da inovação tecnológica ou que dessem conta de tais limitações impostas pela abordagem padrão.

A economia neoclássica padrão, ao partir de pressupostos de racionalidade perfeita, maximizadora e de condições de equilíbrio, tem sido incapaz de fornecer explicações para vários problemas econômicos da vida real.

Ao desconsiderar a dinâmica dos fenômenos econômicos e a complexidade das interações e relações que se travam entre os agentes e entre eles e o ambiente, esses modelos também foram incapazes de tratar da questão da inovação e da mudança tecnológica. ${ }^{1}$ Em decorrência de tal limitação, abriu-se espaço para o desenvolvimento de novas propostas, que buscassem superar as

1. Entretanto, como foi analisado ao longo deste trabalho, essa abordagem vem sofrendo importantes modificações nos seus axiomas, de tal forma que alguns modelos passaram a lidar com a existência de diversidade entre os indivíduos, informação imperfeita e racionalidade limitada. 
deficiências desses modelos partindo de pressupostos menos restritivos acerca do comportamento dos agentes econômicos no sistema. Isso porque, diante de um ambiente que exibe inovações, as hipóteses de racionalidade perfeita, maximização e equilíbrio tornam-se inviáveis, dando lugar aos pressupostos de racionalidade procedimental, escolhas satisfatórias e evolução.

Entretanto, não se pode deixar de enfatizar o domínio da abordagem neoclássica no mainstream econômico, devido, entre outros fatores, às hipóteses extremamente restritivas das quais o modelo parte, o que possibilitava a utilização de modelos altamente estilizados. Esse domínio, entretanto, se deu à custa de perdas no desenvolvimento do conhecimento econômico que levasse em conta suposições mais realistas, como a existência de indivíduos heterogêneos e dotados de racionalidade limitada, mas que possuem capacidade de aprendizado.

Na visão de Colander (2000), a dificuldade de algumas abordagens de ganhar significativo espaço no debate mainstream pode ser atribuída a suas dificuldades em promover essa formalização. Hodgson (1999) reconheceu essa importância e muitas vezes a necessidade da redução a fim de permitir a formalização, mas atacou o completo reducionismo utilizado pela teoria neoclássica, uma vez que as partes se constituem e se condicionam.

Nesse sentido, a abordagem evolucionária ou sistêmica, ao partir de certos pressupostos não reducionistas, como a hipótese de racionalidade limitada, a existência de heterogeneidade, a capacidade de adaptação dos agentes, foi capaz de fornecer um tratamento mais próximo da realidade nas discussões envolvendo o processo de inovação tecnológica e mudança técnica.

Esses modelos trocam a análise estática e a hipótese de equilíbrio por uma análise dinâmica e de desequilíbrio. O ambiente é visto como algo complexo que passa por mutações e carrega incerteza, de tal forma que as decisões tomadas nesse ambiente não são maximizadoras no sentido neoclássico. Mas, apesar desse ambiente de incerteza nas decisões tomadas, os agentes procuram se adaptar às informações recebidas do meio e se auto-organizar, gerando pro- 
priedades agregadas. $\mathrm{O}$ processo de tomada de decisões, de maneira diferente, é expresso por meio de rotinas - que podem ser hereditárias e selecionáveis -, as quais guiam e direcionam o comportamento das empresas.

Feitas as considerações acerca do programa de pesquisa evolucionário, buscou-se identificar as principais características dos sistemas complexos, abordagem que se propõe a analisar os fenômenos sociais de uma perspectiva mais ampla do que aquela empregada pela microeconomia tradicional, que está calcada no modelo de equilíbrio geral. A abordagem dos sistemas complexos desconsidera as hipóteses restritivas com que trabalha a análise padrão, apresentando-se como uma alternativa aos modelos deterministas tradicionais, e fornecendo ferramentas conceituais e de modelagem importantes para o entendimento dos fenômenos econômicos e sociais.

Essa teoria, ao apresentar um arcabouço não reducionista que se fundamenta sobre uma perspectiva evolucionária e sistêmica, concebe a economia como um sistema composto por agentes heterogêneos que interagem entre si, mas que são capazes de se desenvolver e adaptar ao ambiente, isto é, são capazes de se auto-organizar, gerando com isso padrões de auto-ordenamento e estruturas emergentes que não são meramente reduzidas às propriedades das partes.

Mas, apesar da consideração da existência de ordem e regularidade, ou ainda da emergência de estruturas organizadas, na abordagem agent-based, a possibilidade de mudança constante no sistema, resultado das interações ${ }^{2}$ e adaptações entre os agentes, e também a possibilidade do surgimento de comportamento perpetuamente novo e criativo, afasta a economia do steady state.

Dada a complexidade desses fenômenos, torna-se difícil expressar o resultado dessas interações matematicamente, o que conduz à utilização de técnicas de modelagem computacional ba-

2. São caracterizadas como imprevisíveis e incontroláveis. 
seada no agente, que permitem a análise do comportamento fora do equilíbrio e, portanto, a construção de modelos mais realistas.

A modelagem, nesse sentido, tem por principal objetivo descobrir as propriedades emergentes resultantes da interação entre os agentes no sistema. Apesar das dificuldades de previsão desses padrões, pois o sistema está em constante processo de evolução, é possível extrair algumas considerações gerais a respeito do comportamento dos agentes. E tais processos gerados em computadores imitam os processos econômicos da vida real.

Assim, constatou-se que, ao lidar com tais características, a modelagem agent-based mostrou-se bastante apropriada para discutir o processo de inovação tecnológica. Baseando-se em Dawid (2006), considera-se que são duas as principais razões que justificam a utilização do método ABM no tratamento das inovações tecnológicas: i) a sua maior capacidade de incorporar as propriedades genuínas do processo de inovação e mudança tecnológica, dentre as quais a estrutura dinâmica do processo, a natureza do conhecimento, a incerteza forte envolvida e a heterogeneidade das estratégias; e ii) a sua grande habilidade em fornecer explicações aos fatos empiricamente estilizados.

A partir disso, buscou-se entender o processo de inovação tecnológica dentro desse sistema, a partir de uma avaliação de modelos realizados nessa área, os quais, em sua maioria, basearam-se no modelo de concorrência schumpeteriana ${ }^{3}$ de Nelson \& Winter ([1982]/2005), modelo que, devido a sua grande importância e influência, recebeu uma atenção especial neste trabalho.

Nelson \& Winter ([1982]/2005) procuraram construir um modelo de simulação que fosse capaz de admitir e gerar uma diversidade de comportamentos, no nível das firmas individuais, com relação às suas estratégias de produção e inovação; e também que

3. Apesar de apresentar algumas limitações, esse modelo foi capaz de fornecer conclusões importantes acerca da relação entre estrutura de mercado e mudança tecnológica, bem como serviu de base para diversos modelos desenvolvidos posteriormente. 
fosse capaz de explicar os padrões de variáveis agregadas, isto é, os fatos estilizados que emergem das interações no nível micro.

Diante da complexidade envolvida, uma vez que os agentes diferem tanto com relação ao seu estoque de capital e emprego da tecnologia, quanto com relação às diferentes estratégias de produção e inovação, os autores recorreram a métodos de simulação, a fim de gerarem os resultados do modelo, isto é, para verificarem os fatos estilizados, ou características agregadas que emergem como resultado das hipóteses a respeito da forma como os agentes interagem e de como decidem individualmente.

Deve-se enfatizar, ainda, que, diante da hipótese de que as empresas são heterogêneas e, em função disso, apresentam características bastante específicas, os padrões de evolução das indústrias resultantes também apresentarão diversos aspectos muito próprios, de indústria para indústria. Apesar disso, é possível identificar certas características comuns a um grande número de firmas ou, dito de outra maneira, é possível identificar regularidades entre esses padrões gerados.

Ao lidarem com simulações computacionais, os modelos ACE foram capazes de relacionar as estratégias de inovação com a estrutura de mercado e com outras variáveis, como a produtividade, o número de firmas e o crescimento econômico. Mostraram que o processo de seleção entre diferentes estratégias de inovação que se estabelece tende a gerar estruturas bastante diferenciadas uma das outras, afastando assim o sistema das posições de equilíbrio.

Apesar dos grandes avanços verificados por essa abordagem e do seu alto poder explicativo, uma desvantagem apresentada por esses modelos está no fato de requerer a construção de modelos econômicos dinamicamente completos, ou especificações iniciais detalhadas sobre os agentes, além de métodos que determinem seus atributos estruturais, arranjos institucionais e disposições comportamentais.

Diante de tais restrições, de maneira similar à teoria econômica formal tradicional, esses modelos acabam sendo formulados em uma estrutura bastante abstrata, na qual o modelador faz uso de 
hipóteses comportamentais ad hoc, adaptando os pressupostos de acordo com a sua conveniência, a fim de gerar determinados fatos estilizados.

Alguns autores (Dosi \& Winter, 2003; Hodgson, 1999) apontam ainda para a dificuldade de modelar a novidade genuína, isto é, a dificuldade em lidar com inovações que não apresentam relação com as estruturas desenvolvidas no passado.

Tais críticas, no entanto, não são consensuais entre os economistas identificados com essa abordagem e, em geral, é possível concluir que, apesar de apresentar previsões que são carregadas de falhas, a teoria dos sistemas complexos apresenta-se como uma importante ferramenta de análise para o estudo dos problemas econômicos, dada a sua grande capacidade em identificar padrões de auto-ordenamento e estruturas emergentes resultantes da interação entre os agentes. 


\section{Referências bibliográficas}

AGHION, P., HOWITT, P. A model of growth through creative destruction. Econometrica, v.60, n.2, p.323-51, 1992.

ALMEIDA, S. Dinâmica industrial e cumulatividade: o modelo Nelson-Winter revisitado. In: ENCONTRO NACIONAL DE ECONOMIA, 31. Anais... Porto Seguro, 2003.

. Dinâmica industrial e cumulatividade tecnológica. Rio de Janeiro, 2004a. Dissertação (mestrado em Economia) - Instituto de Economia - Universidade Federal do Rio de Janeiro.

. Um modelo evolucionário de busca tecnológica. In: ENCONTRO NACIONAL DE ECONOMIA, 32, Anais... João Pessoa, 2004b.

ANDERSEN, E. S. Reconstructing theory-evolution with special respect to Schumpeter. Aalborg University, Smaskrift, n.69, 1991.

. The difficult jump from Walrasian to Schumpeterian analysis. Aalborg University, Smaskrift, n.78, 1992.

ARNSPERGER, C., VAROUFAKIS, Y. What is neoclassical economics? Post-Autistic Economics Review, n.38, 2006.

ARTHUR, W. B. Competing technologies, increasing returns, and lock-in by historical events. Economic Journal, v.99, p.116-31, 1989.

Complexity in economic theory: inductive reasoning and bounded rationality. American Economic Review, v.84, p.406-11, 1994. 
ARTHUR, W. B. Inductive reasoning and bounded rationality. American Economic Review, v.84, n.2, p.407-11, 1994.

Out-of-equilibrium economics and agent-based modeling. In: TESFATSION, L., JUDD, K. L. Handbook of computational economics. Amsterdã: Elsevier, 2005.

, DURLAUF, S. N., LANE, D. A. The economy as a evolving complex system II. Santa Fe Institute Studies in the Sciences of Complexity. Medwood City: Addison-Wesley, 1997.

AXELROD, R., TESFATSION, L. A guide for newcomers to agent-based modeling in the social sciences. 2005. Disponível em $<$ http://www.econ.iastate.edu/tesfatsi/abmread.htm>. Acesso em 7/1/2009.

BALLOT, G., TAYMAZ, E. The dynamics of firms in a micro-to-macro model: the role of training, learning and innovation. Journal of Evolutionary Economics, v.7, p.435-57, 1997.

. Technological change, learning and macro-economic coordination: an evolutionary model. Journal of Artificial Societies and Social Simulation, v.2, n.2, 1999.

BOWLES, S. Microeconomics: Behavior, Institutions, and Evolution. Nova York: Russell Sage Foundation, 2004.

CACCOMO, J. Technological evolution and economic instability: theoretical simulation. Journal of Evolutionary Economics, v.6, n.2, p.141-55, 1996.

CANTNER, U., PYKA, A. Absorving technological spillovers: simulations in an evolutionary framework. Industrial and Corporate Change, v.7, p.369-97, 1998.

CHIAROMONTE, F., DOSI, G. Heterogeneity, competition and macroeconomics dynamics. Structural Change and Economic Dynamics, v.4, p.39-63, 1993.

COLANDER, D. A thumbnail sketch of the history of thought from a complexity perspective. In: (Org.). Complexity and the history of economic thought. Londres; Nova York: Routledge, 2000.

COOPER, B. Modelling research and development: how do firms solve design problems? Journal of Evolutionary Economics, v.10, p.395-413, 2000.

DAVID, P. A. Clio and the economics of QWERTY. American Economic Review, v.75, n.5, p.332-7, 1985. 
DAWID, H. Agent-based models of innovation and technological change. In: TESFATSION, L., JUDD, K. L. Handbook of computational economics, v.2. Amsterdã: Elsevier, 2006.

BULLNHEIMER, B., REIMANN, M. To innovate or not to innovate? IEEE Transactions on Evolutionary Computation, p.471$-81,2001$.

DEQUECH, D. Rationality and institutions under uncertainty. 1998. Tese (PhD) - University of Cambridge.

. Uncertainty: typology and refinements of existing concepts, mimeo, 2007.

DOSI, G. Institutions and markets in a dynamic world. The Manchester School, v.56, n.2, p.119-46, 1988a.

. Sources, procedures and microeconomic effects of innovation. Journal of Economic Literature, v.27, n.3, p.1120-71, 1988b.

. Technological paradigms and technological trajectories. Research Policy, v.11, p.147-62, 1988c.

The nature of innovative process. In: DOSI, G. et al. (Coord.). Technical change and economic theory. Londres: Pinter Publishers, 1988d.

Mudança técnica e transformação industrial. Campinas: Editora da Unicamp, 2006.

et al. The dynamics of international differentiation: a multicountry evolutionary model. Industrial and Corporate Change, 1994.

DOSi, G., MARSili, O., ORSENIGO, L., SALVATORE, R. Learning, market selection and the evolution of industrial structures. Small Business Economics, v.7, p.411-36, 1995.

DOSI, G., NELSON, R. An introduction to evolutionary theories in economics. Journal of Evolutionary Economics, v.4, n.3, p.153-72, 1994.

DOSI, G., WINTER, S. Interprétation évolucionniste du changement économique. Revue Économique, v.54, n.2, 2003.

ELLIOTT, J. E. Schumpeter's theory of economic development and social change: exposition and assessment. International Journal of Social Economics, v.12, n.6-8, p.6-33, 1985. 
EPSTEIN, J. M., AXTELL, R. Growing artificial societies: social science from the bottom up. Washington: Brookings Institution Press \& The MIT Press, 1996.

FAGIOLO, G., DOSI, G. Exploitation, exploration and innovation in a model of endogenous growth with locally interacting agents. Structural Change and Economic Dynamics, 2003. p.237-73.

FERREIRA, P. C. G., ELLERY JÚNIOR, R. G. Crescimento econômico, retornos crescentes e concorrência monopolista. Revista de Economia Política (São Paulo), v.16, n.62, p.86-104, abr.-jun. 1996.

FOLEY, D. K. Complexity, self-organization, and political economy. In: UNHOLY TRINITY. Labor, capital, and land in the new economy. Londres: Routledge, 2003. p.1-31.

FREITAS, G. G. Economia e sistemas complexos: interações sociais, dinâmicas emergentes e uma análise da difusão da internet na cidade de São Paulo. São Paulo, 2003. Dissertação (mestrado em Economia) - Universidade de São Paulo.

FRIEDMAN, M. Ensaios de economia positiva. Edições Multiplic, ano 1, n.3, fev. ([1953]1981).

GILBERT, N., PYKA, A., ROPELLA, G. E. P. The development of a generic innovation network simulation plataform. Sein Project paper, número 8. The SEIN Project, University of Surrey, 2000.

GILBERT, N., PYKA, A., AHRWEILER, P. Innovation networks: a simulation approach. Journal of Artificial Societies and Social Simulation, v.4, 2001.

GOODWIN, R. M. A growth cicle. In: FEINSTEIN, C. H. (Org.). Socialism, capitalism and economic growth. Londres: Mcmillan, 1967.

GROSSMAN, G., HELPMAN, E. Innovation and growth in the world economy. Cambridge: MIT Press, 1991.

HAHN, F. General equilibrium theory. In: BELL, D., KRISTOL, I. (Org.). The crisis in economic theory. Nova York: Basic Books, 1981. HELLER, C. Path-dependence, lock-in e inércia. In: PELAEZ, V. P., SZMRECSÁNYI, T. (Org.). Economia da inovação tecnológica. São Paulo: Hucitec, 2006. 
HEYLIGHEN, F. Complexity and self-organization. In: BATES, M. J., MAACK, M. N. (Eds.). Encyclopedia of library and information sciences, 2008.

HIGACHI, H. Y. A abordagem neoclássica do progresso técnico. In: PELAEZ, V. P., SZMRECSÁNYI, T. (Org.). Economia da inovação tecnológica. São Paulo: Hucitec, 2006.

, CANUTO, O., PORCILE, G. Modelos evolucionistas de crescimento endógeno. Revista de Economia Política (São Paulo), v.19, n.4, p.53-77, out.-dez. 1999.

HODGSON, G. False antagonisms and doomed reconciliations. In: HODGSON, G. Evolution and institutions. Cheltenham: Edward Elgar, 1999.

INGRAO, B., ISRAEL, G. The invisible hand: economic equilibrium in the history of science. Cambridge, MA: MIT Press, 1990.

KREPS, D. A course in microeconomic theory. Princeton: Princeton University Press, 1990.

KUHN, T. A estrutura das revoluções científicas. São Paulo: Perspectiva, ([1970]2006).

LLERENA, P., OLTRA, V. Diversity of innovative strategy as a source of technological performance. Strutural Change and Economic Dynamics, v.13, p.179-201, 2002.

LUCAS, R. On the mechanics of economic development. Journal of Monetary Economics, v.22, p.3-42, 1988.

MALERBA, F., NELSON, R., ORSENIGO, L., WINTER, S. Competition and industrial policies in a "history-friendly" model of the evolution of the computer industry. International Journal of Industrial Organization, v.19, p.635-64, 2001.

. History friendly models of industrial evolution: an overview of the case of the computer industry. Industrial and Corporate Change, v.8, n.1, p.3-40, 1999.

MALTHUS, T. R. Princípios de economia política e considerações sobre sua aplicação prática. São Paulo: Nova Cultural, 1996.

MARX, K. O método da economia política. In: FERNANDES, F. (Org.). Marx e Engels. São Paulo: Ática, 2003.

NELSON, R. R. Capitalism as an engine of growth. Research Policy, v.19, p.193-214, 1990. 
NELSON, R. R., WINTER. S. G. In search a useful theory of innovation. Research Policy, v.6, p.36-76, 1977.

Uma teoria evolucionária da mudança econômica. Campinas: Editora da Unicamp, ([1982]/2005).

PAVITT, K. Sectoral patterns of technical change: towards a taxonomy and a theory. Research Policy, v.13, 1984.

POSSAS, M. L. Dinâmica da economia capitalista: uma abordagem teórica. São Paulo: Brasiliense, 1987.

. Dinâmica e concorrência capitalista: uma interpretação a partir de Marx. São Paulo: Hucitec, 1989a.

Em direção a um paradigma microdinâmico: a abordagem neo-schumpeteriana. In: AMADEO, E. (Org.). Ensaios sobre economia política moderna: teoria e história do pensamento econômico. São Paulo: Marco Zero, 1989b.

Competitividade: fatores sistêmicos e política industrial - implicações para o Brasil. In: CASTRO, A. B., POSSAS, M. L., PROENÇA, A. (Org.). Estratégias empresariais na indústria brasileira: discutindo mudanças. Rio de Janeiro: Forense Universitária, p.71-117, 1996.

POSSAS, M. L., KOBLITZ, A., LICHA, A., OREIRO, J. L., DWECK, E. Um modelo evolucionário setorial. Revista Brasileira de Economia, v.55, n.3, p.333-77, jul.-set. 2001.

PRADO, E. F. S. Microeconomia reducionista e microeconomia sistêmica. Nova Economia, v.16, n.2, p.303-22, 2006.

RICARDO, D. Princípios de economia política e tributação. São Paulo: Nova Cultural, 1996.

ROMER, P. Increasing returns and long-run growth. The Journal of Political Economy, v.94, n.5, p.1002-37, 1986.

. Endogenous technological change. Journal of Political Economy, v.98, p.71-102, 1990.

. The origins of endogenous growth. Journal of Economic Perspectives, v.8, n.1, p.3-22, 1994.

SAVIOTTI, P. P., METCALFE, J. S. Present development and trends in evolutionary economics. In: (Ed.). Evolutionary theories of economic and technological change: present status and future perspectives. Reading: Harwood Academic Press, 1991. 
SCHELLING, T. C. Micromotives and macrobehavior. Nova York: Norton, 1978.

SCHUMPETER, J. A. The instability of capitalism. The Economic Journal, v.38, n.151, p.361-86, 1928.

. The creative response in economic history. The Journal of Economic History, v.7, n.2, p.149-59, 1947.

. Economic theory and entrepreneurial history. Revista Brasileira de Inovação, v.1, n.2, p.203-24, 1949.

. Capitalismo, socialismo e democracia. Rio de Janeiro: Zahar, ([1943]/1984).

. A teoria do desenvolvimento econômico. 3.ed. São Paulo: Nova Cultural, 1988. (Coleção Os Economistas).

SILVERBERG, G., DOSI, G., ORSENIGO, L. Innovation, diversity and diffusion: a self-organization model. The Economic Journal, v.98, n.393, p.1032-54, 1988.

SILVERBERG, G., VERSPAGEN, B. Collective learning, innovation and growth in a boundedly rational, evolutionary world. Journal of Evolutionary Economics, n.4, 1994.

. An evolutionary model of long term cyclical variations of catching up and falling behind. Journal of Evolutionary Economics, n. 5, 1995.

From the artificial to the endogenous: modeling evolutionary adaptation and economic growth. In: HELMSTADTER, E., PERLMAN, M. (Org.). Behavioral norms, technological progress and economic dynamics. The University of Michigan Press, 1996.

SIMON, H. From substantive to procedural rationality. In: LATSIS, S. Method and appraisal in economics. Cambridge: Cambridge University Press, 1976.

SMITH, A. A riqueza das nações: investigação sobre sua natureza e suas causas. São Paulo: Nova Cultural, 1996.

SOLOW, R. A contribution to the monetary economic growth. Quarterly Journal of Economics, 1956.

STRACHMAN, E. Política industrial e instituições. Campinas, 2000. Tese (doutorado em Economia) - Instituto de Economia - Universidade de Campinas. 
TESFATSION, L. Agent-based computational economics: a constructive approach to economic. Iowa State University, Economics Department, mimeo., 2005.

WALRAS, M. E. L. Compêndio dos elementos de economia política pura. São Paulo: Nova Cultural, 1996.

WIBLE, J. What is complexity. In: COLANDER, D. (Org.). Complexity and the history of economic thought. Londres e Nova York: Routledge, 2000.

WINDRUM, P., Neo-Schumpeterian simulation models. MERIT-Infonomics Research Memorandum, Maastricht University, 2004.

WINTER, S. Schumpeterian competition in alternative technological regimes. Journal of Economic Behavior E Organization, v.5, p.287-320, 1984.

. Modeling industrial dynamics with innovative entrants. Strutural Change and Economic Dynamics, v.11, p.255-93, 2000.

, KANIOWSKI, Y., DOSI, G. A baseline model of industry evolution. Journal of Evolutionary Economics, v.13, p.355-83, 2003. 


\author{
SOBRE O LIVRO \\ Formato: $14 \times 21 \mathrm{~cm}$ \\ Mancha: 23, $7 \times 42,10$ paicas \\ Tipologia: Horley Old Style 10,5/14 \\ 2010 \\ EQUIPE DE REALIZAÇÃO \\ Coordenação Geral \\ Tulio Kawata
}





\section{CULTURA}

ACADÊMICA

Editona 